\title{
Equality Trouble: Sameness and Difference in Twentieth-Century Race Law
}

\author{
Angela P. Harris $\dagger$
}

\section{TABLE OF CONTENTS}

Introduction

I. The First Reconstruction: Prelude to the Twentieth Century

A. The Legal Structure of the First Reconstruction

B. Dismantling Reconstruction: The Southern Redemption

II. Race Law in the Age Of Difference.

A. Civilization and Self-Determination: The Increasing Importance of Race

B. Race Law and Nonwhite Subjects in the Age of Difference

1. Plenary Power and Nonwhite Citizens: Beyond the Scope of Equality

2. Equality in an Age of Difference: Nonwhite Citizens and the End of Emancipation

a. Turning Domination into Difference

b. Nonstate Action as Race Law.

C. Race Law and White Subjects im the Age of Difference: Maintaining the Quality of Whiteness

1. Whiteness and Nationalism: Americanizing Non-Anglo-Saxons

Copyright $\odot 2000$ Angela P. Harris. California Law Review, Incorporated (CLR) is a California nonprofit corporation. CLR and the authors are solely responsible for the content of their publications.

$\dagger$ Professor of Law, University of California, Berkeley, School of Law (Boalt Hall). My thanks to Catharine Wells and Joan Williams, for reading and providing perceptive commentary on an early draft of this essay; to Martha Mahoney and Lisa Iglesias, for sharing with me their thoughts about the economic dimensions of white supremacy; to the participants in a faculty workshop at Georgetown Law School, including Alexander Aleinikoff, Richard Chused, Charles Lawrence, Lynn Stout, and Robin West; and to Monika Batra, Boalt ' 01 and Joanna Stromberg, Boalt '02, for their research support and emotional cheerleading. Finally, my thanks to Jerome Culp and to Duke Law School for the generous provision of summer library and computer support, and to the Boalt Hall Fund for summer research support. An expanded version of this essay will appear in a book forthcoming from Harvard University Press.

I apologize in advance for the many omissions and mistakes certain to occur in an essay as sweeping as this one, undertaken by a non-historian no less. It should go without saying that the responsibility for these is mine alone. 
D. Summary: The New Equilibrium 1981

III. The Second Reconstruction and the Continuing Significance of Race 1982

A. The Destabilization of the Old Racial Equilibrium...................1984

B. The Elements of the Second Reconstruction ............................. 1989

1. Civil Rights Law from the First Reconstruction .................. 1989

2. The Second Reconstruction in Congress .............................1993

3. The Retreat of Plenary Power ............................................. 1996

C. The Empire Strikes Back: Elements of Social Resistance

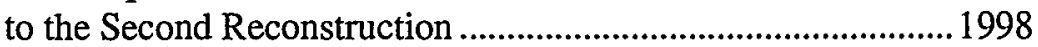

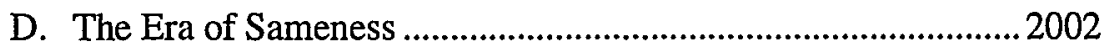

1. Discrimination as Differentiation............................................2004

2. The Rule of Intent: Distinguishing "Racial" from "Nonracial" Action .................................................................. 2009

3. Racism and the Limits of Courts........................................... 2012

Conclusion: Race Law and Equality Trouble .....................................2014 


\title{
Equality Trouble: Sameness and Difference in Twentieth-Century Race Law
}

\author{
Angela P. Harris
}

In this Essay, Professor Harris suggests that "race law" consists not only of antidiscrimination law, but law pertaining to the formation, recognition, and maintenance of racial groups, as well as the law regulating the relationships among these groups. Harris argues that a constant tension in the story of race law in the past century has been the effort to reconcile constitutional and statutory norms of equality with the desire for white dominance. In the first part of the century, it was assumed that the fact of racial difference required management through sound public policy; in the second part of the century, race gradually became understood as an arbitrary distinction that the law should ignore. Neither treating race as difference nor as sameness, however, has succeeded in accomplishing racial justice.

The white race deems itself to be the dominant race in this country. And so it is, in prestige, in achievements, in education, in wealth and in power. So, I doubt not, it will continue to be for all time, if it remains true to its great heritage and holds fast to the principles of constitutional liberty.

- Plessy v. Ferguson, 163 U.S. 537, 559 (1896) (Harlan, J., dissenting)

[T] he problem of the Twentieth Century is the problem of the color-line.

- W.E.B. Du Bois, The Souls of Black Folk

\section{INTRODUCTION}

Five years before the turn of the twentieth century, the Supreme Court, in Plessy v. Ferguson, ${ }^{2}$ upheld a Louisiana statute requiring the segregation of white and black people in railway cars against an equal

1. W.E.B. Du BoIs, The SOULS OF BLACK FolK vii (2d ed. 1953) (1903).

2. 163 U.S. 537 (1896). 
protection claim. Justice Harlan wrote a ringing dissent. Declaring that "[o]ur constitution is colorblind," he argued that the racial segregation in this case did not signify equality but the inferiority of one class and the superiority of the other.

As the twenty-first century begins, Harlan's dissent has become the majority view. As a social matter, de jure racial segregation has become anathema, a prime example of political and social evil. As a legal matter, Justice Harlan's position has also prevailed. Racial segregation is considered presumptively unconstitutional. And Justice Harlan's statement, "[o]ur constitution is colorblind," now serves as a guiding principle in Supreme Court jurisprudence. Yet, oddly enough, the language of "colorblindness"-once a ringing call for equality-is now seen in many progressive quarters as code language for the perpetuation of racial inequality. The subject of this Essay is how we got from there to here.

History has many uses. I have accepted the invitation of the California Law Review to examine the law in my area between the arbitrary dates 1901-2001 neither to uncover forgotten materials nor to give the reader a sense of the "pastness of the past." Rather, my aim is to shed some light on where race law and the project of racial equality are now, at the beginning of the twenty-first century. My argument is that ever since race law became indissolubly linked with the principle of equality during the first Reconstruction, American legislators, jurists, executives, and administrators have had to struggle with a tension between the interests of those groups wishing to preserve the political, economic, and social status quo and those groups demanding fundamental social change. W.E.B. Du Bois called this struggle "the problem of the color-line," and named it as the problem of the twentieth century.

In the first half of the century, the struggle between racialized elites and non-elites took place in a world in which everyone agreed race made a fundamental difference in social life. Now, at the end of the century, race relations in the United States have been transformed for the better. Race, it is now agreed, is a meaningless and arbitrary. difference; it is the content of one's character, not the color of one's skin, that matters. Yet the problem of the twenty-first century also appears to be the color line, though in a sense far different than W.E.B. Du Bois intended. The language of race has been declared meaningless at a time when we have very little language left in which to talk about questions of structural inequality, of caste and class, of labor, democracy, and the relationship between redistribution and recognition. At the end of the century, race talk is simultaneously the most powerful language we have to invoke moral and constitutional principles and a language that obscures as much as it reveals.

Given the importance of equality norms in American race law, the story of race law is often treated simply as the story of equality law and 
equality law as antidiscrimination law. Yet the reduction of race law to equality law immediately shifts some pertinent issues out of sight. First, the equation of race law with equality law leaves out the many areas of law, including but not limited to immigration, naturalization, tax, family, and inheritance law, that have shaped and continue to shape American race relations.

Second, not all racialized groups have primarily organized their struggles around equality. Indian nations, for example, have consistently fought not for "equality" within the American nation, but for some version of "sovereignty" or self-determination-the right to resist extinction or assimilation by the United States. Along with Puerto Ricans, residents of United States "territories," and groups with legally unacknowledged claims to political independence such as Native Hawaiians, Indians have similarly resisted being treated as a "race," particularly if such treatment means assimilation. ${ }^{3}$ At the same time, the assumption of fundamental group-based differences between Indians and non-Indians upon which much of federal Indian law and policy is built, and the use of state law to establish and maintain group relations of dominance and dependence, entwines notions of descent, inherent (cultural) difference, "blood," and legal power in ways too familiar to a student of race to be ignored. ${ }^{4}$

Third, the equation of race law with equality law tends to obscure the fact that race in the United States has always been not just a matter of class struggle, but also class formation. The equality primciple provides a means for regulating relationships among social groups; yet, it has begun to be common knowledge that racial groups are not "natural" groups but social creations, and law has played an important role in this creation. The equation of race law with equality law tends to obscure the law's participation in creating and maintaining racial distinctions, and thus subtly perpetuates the notion that races just naturally are and that equality law simply provides a neutral forum for conflict aniong them.

Fourth and finally, much of race law in the past century (and no doubt in the centuries to come) has operated not through judges and legislators, but through bureaucrats, police officers, and even through "private" citizens whose interests converged with or diverged from the interests of the racial state. A fuller account of the century's race law might trace, for

3. See, e.g., VINE Deloria, JR., CUSTER Died FOR Your Sins 168-74 (1969); Williamson B.C. Chang, The "Wasteland" in the Western Exploitation of "Race" and the Environment, 63 U. CoLo. L. REv. 849, 864 (1992) ("The debate on race, and its means of discounting indigenous claims by understanding them as consistent with claims of all 'people of color,' diverts both world and domestic attention from the very straightforward claims of America's indigenous people.").

4. The Supreme Court recently denied a state voting scheme intended to further the political autonomy of native Hawaiians on grounds that it trammeled the voting rights of non-Hawaiians on the basis of race. See Rice v. Cayetano, 120 S. Ct. 1044 (2000). Similar schemes on behalf of Indians, however, have been treated as making "political" rather than "racial" distinctions. See Morton v. Mancari, 417 U.S. 535 (1974). 
example, the operation of racial categories and prohibitions in federal administrative law, state law, local ordinances, and the unwritten "customs" that formed the foundation of Jim Crow. A fuller account might also include more than a glimpse of the extralegal practices of discrimination, abuse, and terror-both "private" and "public" - that kept nonwhite persons "in their place."

In this Essay, I mean by "race law" law pertaining to the formation, recogmition, and maintenance of racial groups, as well as the law regulating the relationships among these groups. For reasons of space and training, 1 have adopted in this Essay the conventional focus on Supreme Court opinions and, secondarily, statutes as an expression of "the law." But it will be useful to remember from time to timie that state law is not the only law there is. Above all, it will be useful to recognize that race law is broader than antidiscrimination law.

If equality law does not comprise the whole of race law, nevertheless we cannot account for the equality trouble we are in without recognizing the enormous influence on and importance of equality jurisprudence to race law. A theme that structures this Essay is the story of how the American legal and social order adjusted to equality, "America's Anglo-African word."5 Although the Drafters of the Declaration of Independence held as a self-evident truth that "all men are created equal," preserving or creating equality was not of prime importance to them; nor was equality a core principle for the Framers of the Constitution. ${ }^{6}$ It was out of the great war between the slave states and free states that the idea of equality emerged as central to the American nation's purpose, and in that battle African Americans were central. By the end of the Civil War, African Americans had helped push first abolitionists and then Radical Republicans toward the cause of equality to make sure that the end of slavery would leave black people fully American.

But the content of "equality" was, of course, uncertain. Consider the first epigraph of this Essay, taken from Justice Harlan's famous dissent. Justice Harlan has argued vigorously that the social meaning of separate black and white railway cars is not equality but dominance, and that the Fourteenth Amendment cannot countenance such dominance. At the same time, as the quote suggests, Harlan does not reject the notion of the white race as a social group with its own separate and distinct traditions and heritage. Indeed, Harlan recognizes the white race as in fact the dominant race in American social life. The argument between the majority and

5. See, e.g. Celeste Michelle Condit \& John louis Lucaites, Crafting EQUALITY: AMERICA's ANGLO-AFRICAN WORD (1993).

6. See Garry Wills, Lincoln at Getrysburg: The Words that Remade America 99-109 (1992) (arguing that President Lincoln's Gettysburg Address reinterpreted these earlier texts in light of the new principle of equality). 
dissent, then, is not over whether whites should be dominant in social life, for they clearly are and perhaps deserve to be. The argument concerns a different question: Where is the line between that permissible and perhaps praiseworthy social dominance and the legal dominance the Constitution now forbids?

In this Essay, I suggest that part of the story of race law in this past century has been the effort to reconcile constitutional and statutory equality norms with the desire of the white race to remain "dominant... in prestige, in achievements, in education, in wealth, and in power."7 The attempt to reach equilibrium between these competing pressures has led both to constantly shifting boundaries of the realm of equality itself, and to different notions of equality's meaning. As to the latter, two basic alternatives seem endemic to discourses of equality: equality as "sameness" and equality as "difference." In the first part of the century, I will argue, constitutional equality encompassed the notion of inherent racial difference, though largely expressed in terms of cultural rather than biological difference. In the latter part of the century, the language of equality underwent a profound shift. Now racial "sameness" is the foundation of constitutional common sense: race, it is largely agreed, is a distinction that should make no difference.

It matters tremendously whether Americans think of themselves as divided up into races, each with its own distinct heritage, traditions, and destiny, or whether, in agreement with Justice Scalia, they see themselves as just one race: "American." Yet, as feminist scholars know, both equality as sameness and equality as difference have a way of obscuring questions such as "who sets the standard for equality?" The fact that both equality as sameness and equality as difference can coexist with relations of dominance begims to explain why many of today's antiracists denounce colorblindness. It also begins to explain how we may not have made as much progress over the past century as it might imitially appear.

Analyses of United States race relations can be divided into basically optimistic stories, like the popular "immigrant story" that ends with all groups equally contributing to America's melting pot, or basically pessimistic stories, such as Derrick Bell's reluctant conclusion that racism should be considered permanent. ${ }^{9}$ In this account, I have been influenced by Reva Siegel's approach to America's race story, an approach that

7. Plessy v. Ferguson, 163 U.S. 537, 559 (1896) (Harlan, J., dissenting).

8. Adarand Constr. Co. v. Pena, 515 U.S. 200, 239 (Scalia, J., concurring).

9. For the view that racism is permanent (though ever-changing in form), see generally DERRICK Bell, Faces at The BotTom of THE WELl (1992). For the more widely shared view that the United States, led by the Supreme Court, is slowly but steadily expanding the national community to include women, people of color, gays and lesbians, and other disenfranchised groups, see KENNETH KARST, Betonging to AMERICA 215 (1989) (asserting the Court's leadership in this process). 
strives to be agnostic. ${ }^{10}$ Siegel's argument suggests that, when we look closer at the history of race law, stratification by race neither inevitably disappears before the advancing front of legal equality, nor remains the same. Rather, seemingly radical shifts in the law in the direction of equality frequently result in not the disappearance but the transformation of relations of inequality. Siegel warns us to be continually aware of the possibility that what seems like justice in one century may be seen as injustice in the next. In this spirit of caution and skepticism, I embark on the project of examining the past century. ${ }^{11}$

\section{I}

\section{The First Reconstruction: Prelude to the Twentieth Century}

Plessy v. Ferguson is a useful symbol for the great shift in race law that was underway at the opening of the twentieth century. To understand the nature of that shift, however, it is necessary to move backward in time to the first Reconstruction, the turbulent period from 1865 to 1877 . During this period, four million people were suddenly legally transformed from chattel into citizens of the United States; ${ }^{12}$ whites in California became increasingly wracked with hatred of the Chinese (a violent struggle known euphemistically as the "Chinese question"); ${ }^{13}$ and Anglos and people of Mexican descent struggled in the southwestern states over land and political power. ${ }^{14}$ During this period, as well, Indians were being forced from their lands, and found their economies and their cultural and spiritual

10. See Reva Siegel, Why Equal Protection No Longer Protects: The Evolving Forms of StatusEnforcing State Action, 49 STAN. L. REv. 1111 (1997). Siegel suggests a "simple proposition":

The ways in which the legal system enforces social stratification are various and evolve over time. Efforts to reform a status regime bring about changes in its rule structure and justificatory rhetoric-a dynamic I have elsewhere called "preservation-throughtransformation." In short, status-enforcing state action evolves in form as it is contested. Id. at 1113 (footnote omitted).

11. Before continuing, I should also note that, as a non-historian, I have gratefully relied on the work of others. Two particularly detailed, thoughtful, and multicultural accounts of the history of American race law are BenJamin Ringer, "We THE PeOple" and OTHERs: DuAlity and AMERICA's Treatment of Its Racial Minorities (1983) and Rogers Smith, Civic Ideals: Conflicting Visions OF CITIZENSHIP IN U.S. HiSTORY (I997).

12. See ERIC Foner, Reconstruction: AMERICA's UNFINISHEd REvolution I863-1877 (Perennial Library ed. 1989).

13. See generally Charles McClain, In Search of Equality: The Chinese Strugglf Against Discrimination in Nineteenth Century America (1994) (discussing anti-Chinese discrimination and.Chinese efforts to protect themselves); LUCY SALYER, LAwS AS HARSH AS Tigers: Chinese IMmigrants and the Shaping of Modern ImMigration LAw (1995) (discussing the legal and social history of restrictive anti-Chinese immigration policies in the United States).

14. See generally Malcolm EBright, LAND GRANTS AND LAwSUITS IN NoRTHERN New Mexico (1994); Guadalupe T. Luna, Chicana/Chicano Land Tenure in the Agrarian Domain: On the Edge of a "Naked Knife," 4 Mich. J. RACE \& LAW 39 (1998); Symposium: Understanding the Treaty of Guadalupe Hidalgo on Its 150th Anniversary, 5 Sw. J. L. \& TRADE AM. 5-207 (1998). 
integrity undermined by state policies of "removal" and "allotment."15 Reconstruction was also a period when, in historian Eric Foner's words, "Americans made their first attempt to live up to the noble professions of their political creed-something few societies have ever done." ${ }^{16}$ Although the attempt ultimately failed, the introduction of equality principles into constitutional discourse and the vision of a strong national state would be enduring legal legacies for the times to come.

In Part I.A, I briefly describe the legal structure of the "first Reconstruction." In Part I.B, I describe the political and legal conditions that led to the partial dismantling of Reconstruction and the triumphant "Redemption" of the South.

\section{A. The Legal Structure of the First Reconstruction}

The Radical Republicans who wielded power in Congress at the end of the Civil War had a new vision for the United States: "the utopian vision of a nation whose citizens enjoyed equality of civil and political rights, secured by a powerful and beneficent national state." ${ }^{\prime 17}$ Neither equality as a principle nor the notion of a strong national state had been a part of the constitutional framework before the Civil War. It was the task of the Republicans, then, to fundamentally alter American law.

As a legal framework, Reconstruction consisted of three constitutional amendments-the Thirteenth, Fourteenth, and Fifteenth-and a myriad of federal statutes protecting "civil rights." Section one of the Thirteenth Amendment (1865) abolished slavery and gave Congress the power to enforce the prohibition with further legislation. ${ }^{18}$ It was widely feared, however, that the Thirteenth Amendment did not go far enough to secure the freed slaves in their new legal existence. Hence, section one of the Fourteenth Amendment (1868), providing that "[a]ll persons born or naturalized in the United States, and subject to the jurisdiction thereof, are citizens of the United States and of the state wherein they reside," made citizenship national for the first time. ${ }^{19}$ This Amendment laid to rest the ghost of Dred Scott, in which all American descendants of Africans, whether free or slave, had been set outside the bounds of citizenship. ${ }^{20}$ The Fourteenth Amendment further prohibited the states from abridging the

15. See generally Frederick Hoxie, A Final Promise: The Campaign to Assimilate the 1ndians, 1880-1920 (1984); Francis Prucha, American Indian Policy in Crisis: Christian Reformers and the Indians, $1865-1900$ (1964); Francis Prucha, The Great Father (1984).

16. FONER, supra note 12 , at xxvii.

17. Id. at 230 .

18. U.S. CONST. amend. XIII, § 1 ("Neither slavery nor involuntary servitude, except as a punishment for crime whereof the party shall have been duly convicted, shall exist within the United States, or any place subject to their jurisdiction."). Section 2 gave Congress the power "to enforce this article by appropriate legislation." Id. $\S 2$.

19. U.S. CoNST. amend. XIV, § 1.

20. See Dred Scott v. Sandford, 60 U.S. (16 How.) 393 (1856). 
privileges or immunities of any United States citizen, or depriving any citizen of due process or equal protection of the law. Finally, in 1870, the Fifteenth Amendment, guaranteeing the vote to all men regardless of race or color, was declared ratified. ${ }^{21}$

The Reconstruction Amendments were accompanied by a series of federal statutes directed at disnuantling state race law and forestalling the creation of new legal forms of racial oppression. For instance, the Civil Rights Act of $1866^{22}$ and the Fourteenth Amendment were passed to stop the Southern states from recreating slavery in all but name through the infamous "Black Codes." 23 Around the same time, the Reconstruction Congress also greatly expanded citizens' ability to renıve cases to federal court, ${ }^{24}$ and abolished peonage, a form of indentured servitude that had oppressed Indians and Mexicans living under Spanish rule in the territory of New Mexico. ${ }^{25}$ Two months after the passage of the Fifteenth Amendment, Congress passed the Civil Rights Act of 1870. In addition to giving some substance to the constitutional voting guarantee, the act made illegal the California practice of subjecting Chinese to special taxes, and nullified state legal rules that forbade Chinese persons from testifying in court against white persons. ${ }^{26}$ The Reconstruction Congress also passed legislation intended to provide a federal tool against white legal and extralegal violence. In April of 1871, Congress passed the "Ku Klux Klan Act"27 in

21. U.S. CoNST. amend. XV, § 1 ("The right of the citizens of the United States to vote shall not be denied or abridged by the United States or by any state on account of race, color, or previous condition of servitude."). Section 2 was an enabling clause which was intended to serve as a basis for further federal legislation. See id. $\$ 2$.

22. 14 Stat. 27 (1866). Enacted over the veto of President Johnson, the 1866 Act provided that persons born in the United States and not subject to any foreign power were citizens of the United States, thus overruling the decision in the Dred Scott case. It also provided that citizens, without regard to color, were entitled in every state and territory to the same right to contract, sue, give evidence, and take, hold and convey property, as was enjoyed by white citizens and provided for criminal penalties upon its violation. See William E. Nelson, The Fourteenth Amendment: From Political Principle to Judicial Doctrine 104 (1988).

23. See FONER, supra note 12 , at 257.

24. See id. at 277 (describing the Habeas Corpus Act).

25. See Francis Biddle, Civil Rights and the Federal Law, in SAFeguarding Civil Liberty TODAY 109, 119 (Carl Lotus Becker ed., 1945).

26. 16 Stat. 141 (1870). Section 16 of the 1870 Act included all persons within the jurisdiction of the United States. The use of the word "persons," rather than "citizens," represented a victory by Chinese activists, since the Chinese were resident aliens rather than citizens. See CHARLES J. McClaIN, Jr., In Search of Equality: The Chinese Struggle Against Discrimination in Nineteenth Century America 39-40 (1994); Charles J. McClain, Jr., The Chinese Struggle for Civil Rights in Nineteenth Century America: The First Phase, 1850-1870, 72 Calif. L. REv. 529 passim (1984) (describing the Chinese campaign for civil rights and the wording of the bill introduced in response, which eventually became section 16 of the 1870 Act).

27. The act made it an offense to "conspire together, or go in disguise upon the public highway or upon the premises of another for the purpose ... of depriving any person or any class of persons of the equal protection of the laws, or equal privileges or immunities under the laws." 17 Stat. 13 (1871). The act also provided a federal civil remedy against law enforcement officers who failed to protect 
response to the widespread terrorism against blacks and white "carpetbaggers" (white emigrants from the North) in the southern states. A final aspect of Reconstruction legislation was the effort to entitle all citizens, regardless of color, to the full enjoyment of public life in the name of equality. In 1875 , for example, Congress passed a civil rights act directed toward public accommodations. ${ }^{28}$

Reconstruction transformed the political life of the United States, especially in the South, where African Americans surged to the polls, into political clubs, and into statehouses and houses of Congress. Now subjects rather than objects of the law, the freed slaves organized to learn about and enforce their rights, engaged in strikes, and agitated for land redistribution. They worked with carpetbaggers and "scalawags" (white Southerners who allied theinselves politically with the freed slaves) toward economic development, civil rights legislation, and the establishment of public school systems. For a time, a new interracial society seemed on the verge of emerging in the heart of Dixie.

Yet there were important weaknesses in the Reconstruction political and legal franiework that would allow it to be significantly undermined im just a few years. The first weakness was the absence of a solid economic foundation for the freed slaves' entry into the republic. African Americans' hopes for land redistribution, symbolized by the cry "Forty acres and a mule,"29 were never realized; despite the efforts of "Black Republican" judges and politicians to shift economic power to sharecroppers and white tenant farmers, the national government ultimately relied on civil and political rights rather than economic independence as the guarantor of freedom. Ultimately, land in the postwar south was left in the hands of the former slaveholders. ${ }^{30}$

Another weakness in the Reconstruction franiework was the absence of a solid enforcement structure for the freedpersons' newly created rights. The Freednien's Bureau - the inajor federal administrative agency charged with implementing black emancipation-had always been viewed as temporary, and was dissolved in 1866. The Justice Department was not

victims of such terrorism. See id.; Monell v. Dept. of Soc. Servs., 436 U.S. 658, $665-76$ (1978) (describing the 1871 Act's legislative history).

28. See Theodore Eisenberg, Civil Rights Legislation: Cases and Materials 27 (4th ed. 1996). Section 1 of the 1875 Act required all inns, public conveyances, theaters, and other places of public amusement to open their accommodations and privileges to "all persons within the jurisdiction of the United States," subject only to "conditions applicable alike to citizens of every race and color, regardless of any previous condition of servitude." 18 Stat. 335 (1875).

29. General Sherman's Field Order 15 called for distributing land confiscated from or abandoned by planters to freedmen in forty-acre homesteads, "where by faithful industry they can readily achieve an independence." FoNER, supra note 12, at 159 (quoting General Rufus Saxton, Freedman's Bureau Director in Georgia, South Carolina, and Florida). The forty-acre figure was also used by Republican Thaddeus Stevens in an 1865 speech to Pennsylvania's Republican Convention. See id. at 235-36.

30. See William E. Forbath, Caste, Class, and Equal Citizenship, 98 MrсH. L. Rev. 1, 32-34 (1999). 
prepared for the enormous task of administering black legal rights in the new South. Indeed, most Republicans, like Democrats, assumed that the primary power of law enforcement lay with the states, and hoped that black people could protect themselves politically through the vote. But Republican commitment to black suffrage would weaken in just a few years, and black people would gradually see the right to vote slip away.

A third weakness in the Reconstruction framework lay in the very grandiosity and novelty of its legal structure. There were disputes from the beginning over the import of the Thirteenth Amendment: was it a grand principle enacting a condition of "freedom" for all citizens, or was it merely a narrow rule forbidding forced labor without pay? The Fourteenth Amendment, for its part, introduced new and cryptic language into constitutional jurisprudence. What were the "privileges or immunities" of citizens of the United States, and what might "equal protection" mean? Above all, how much did the Reconstruction Amendments shift power away from the states and invest the national government with new authority, overturning traditional understandings of federalism? The amendments, with their broad but vague language, did not answer such questions.

The ambiguities were politically necessary. Even the Radical Republicans did not agree among themselves on how far racial "equality" should go. But the ambiguities in the Reconstruction Amendments that permitted their passage would also permit a hostile Supreme Court to eviscerate them, and many of the statutory provisions enacted under them, within a few years.

In addition to these weaknesses within the Reconstruction framework, it is important to note that the ambitions of the Reconstruction Congress, though sweeping, were nevertheless limited from a contemporary perspective. For example, Reconstruction was concerned primarily with alleviating the condition of African Americans, though its effort to abolish legal race and color discrimination had important implications for race law more generally. Thus, with the exception of the 1867 anti-peonage act, Reconstruction did not address the rights of Mexican Americans, who had, under the 1848 Treaty of Guadalupe Hidalgo, been promised legal protection of their land and property in the areas that had become New Mexico, Arizona, and other states but whose ability to vote depended on how the new western states viewed their racial identity. ${ }^{31}$ Reconstruction did not address the legal and political rights of Indians, many nations of whom had been forcibly "removed" from their land to free it up for white settlement and exploitation, and who would soon see their remaining land holdings split up by "allotment." Indeed, the existence of Indians in legal Reconstruction is marked only by a cryptic phrase exempting them from

31. See Robert F. Heizer \& Alan F. Almquist, The Other Californians 92-119 (1971). 


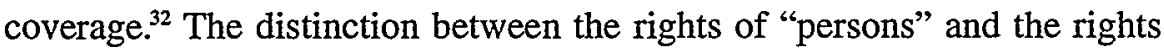
of "citizens" in the Fourteenth Amendment and in the Reconstruction civil rights acts carefully negotiated a compromise between a vision of universal racial equality and the hatred for Chinese immigrants dominating state politics in California and the Pacific Northwest. ${ }^{33}$

The unique constitutional status of Indians had already set them apart from other nonwhite groups. The legal structure of Reconstruction further divided American race law into two tributaries: a body of law applicable to African Americans and other nonwhite citizens, in which racial equality was the norm, and a body of law applicable to nonwhite noncitizens, which would continue to openly link legal rights to racial status. ${ }^{34}$ Even in the realm of equality, Reconstruction had no ambitions to create "social equality" between whites and nonwhites. ${ }^{35}$ The preservation of the "social" as a sphere beyond the law of equality would, in the new century, allow courts hostile to the Reconstruction program to recharacterize civil rights as social rights beyond the power of Congress to guarantee. More generally, the preservation of "the social" as a sphere beyond equality allowed for the continued creation and maintenance of racial inequality outside the official reach of the state.

Despite its failures and limitations, however, legal Reconstruction provided new tools, not only for the struggle against white supremacy, but for struggles against oppression of all kinds. The most important legacy of Reconstruction for the new century would be the idea of "equality," a principle that nonwhite legal activists and their white allies would use as both a sword and a shield against racial hierarchy.

32. For example, the phrase in the Fourteenth Amendment, "and subject to the jurisdiction thereof," was meant to exempt Indians. See Elk v. Wilkins, 112 U.S. 94 (1884); NELson, supra note 22 , at 102-03.

33. See John Hayakawa Torok, Reconstruction and Racial Nativism: Chinese Immigrants and the Debates on the Thirteenth, Fourteenth, and Fifteenth Amendments and Civil Rights Laws, 3 AsIAN L.J. 55 (1996).

34. Reconstruction also did not give women the vote, despite the efforts of suffragists like Elizabeth Cady Stanton. Thus black women, for example, would in the wake of Reconstruction enjoy the benefits of higher education and religious and political leadership within their communities, but they had no direct voice in electoral politics. See GlendA ElizABETH GILMORE, GENDER AND Jim CRow 43 (1996) (arguing that black women, because of the overriding commitment to "uplift the race," enjoyed more freedom than white women in the same period to combine marriage with public life); see also FONER, supra note 12, at 447 (arguing that the desire to keep poor whites from voting in many states kept the drafters of the Fifteenth Amendment from prohibiting literacy, property, and educational restrictions on the franchise).

35. As Foner writes:

[S]ocial relations-the choice of business and personal associates-most Americans deemed a personal matter, outside the purview of government. Throughout Reconstruction, indeed, the term "social equality" conjured up fantastic images of blacks forcing their way into whites' private clubs, homes, and bedrooms. "Negro equality, ..." [Thaddeus] Stevens assured the House, "does not mean that a negro shall sit on the same seat or eat at the same table with a white man. That is a matter of taste which every man must decide for himself."

FoNER, supra note 12, at 231 (footnote omitted). 


\section{B. Dismantling Reconstruction: The Southern Redemption}

By 1877, the tide had turned against the Republican vision of racial inclusion. The Republican Party was in trouble, having failed to solidify its support in the South. The presidential election of 1876 pitted Republican Rutherford B. Hayes against Democrat Samuel J. Tilden, in a campaign notable both for violence against black voters and for outright fraud..$^{36}$ The results of the election were disputed; meanwhile, many Republicans urged the party to back away from African Americans and to woo the "Old Whig" or "better class" of white Southerners. In the white South, meanwhile, the cry was for "states' rights" and "home rule." The compromise of 1877 granted the election to Hayes, but also delivered the "home rule" white Southerners demanded; and this home rule was the cornerstone for what became known as the Southern Redemption. ${ }^{37}$ Under the governments of the Southern Redeemers, state budgets were slashed to reduce "big government" and to lower taxes; states withdrew fiscal support for schools, hospitals, and other social services. ${ }^{38}$ And beginning in the Deep South, with the Republican Party in disarray, black people saw their newly-found political power steadily undermined. Voting fraud, terror, and outright refusal to obey the law-for example, state officials refusing to register blacks to vote-contributed to this loss of black political power. But elite southerners also used legal means to disenfranchise black and poor white voters, working within a new "colorblind" framework. African Americans in North Carolina, for example, were disfranchised by a "raceneutral" amendment to the state constitution. Stirring up white hysteria about the sexual threat black men posed to white women, and promising poor whites that the Party would lift them up, the Democrats had successfully broken the back of the fragile political alliance between blacks aud whites within the Populist Party. Under the new amendment, in order to vote, all men would be required to pay a poll tax and, except for those whose ancestors had been eligible to vote prior to January 1,1867 , to pass a literacy test. The amendment would take effect on July 1, 1902, but those whose ancestors could have voted would not have to take the literacy test until 1908, the so-called "grandfather clause." As Glenda Gilmore reports:

When northerners questioned North Carolina's disfranchising amendment, the Democrats responded in reasoned tones that

36. See id. at 570-75.

37. As Eric Foner points out, although the end of Reconstruction was articulated in the language of states' rights, President Hayes did not hesitate to use federal power in other areas. For example, Hayes removed the Nez Perce Indians from their Oregon homeland, broke strikes, and prevented union meetings during the Great Strike of 1877. See id. at 583-84.

38. The drastic reduction of government services hurt poor whites as well as blacks. For example, Foner notes, "Louisiana spent so little on education that it became the only state in the Union in which the percentage of native whites unable to read or write actually rose between 1880 and $1900 . "$ Id. at 589 . 
evoked good government and the integrity of the ballot. With poor illiterate white men back home, however, the Democrats struck the same old note. To hell with constitutional issues, shouted Alfred Moore Waddell ... "The only issue is are you a white man or are you a negro?" he challenged the crowds. Waddell even conceded that North Carolina had violated the Fifteenth Amendment. That mattered little, he gloated, for 'there aren't enough soldiers in the U.S. Army to make whites give up the vote." 39

One historian reports that "[b]y the end of the year 1900, thirty years after the enactment of the Fifteenth Amendment, Louisiana and North Carolina had amended their state constitutions to disfranchise the vast majority of blacks, and Alabama and Virginia were in the process of calling or holdnig disfranchising conventions." ${ }^{\prime 0}$ Redemption was underway in the Supreme Court as well. Although the Fifteenth Amendment reniained good law in principle, ${ }^{41}$ in practice the experiment in multiracial democracy was over. The Supreme Court upheld poll taxes and literacy requirements in Williams v. Mississippi ${ }^{42}$ serenely reasoning that such new regulations merely measured merit, not race. Nineteen hundred and one was the last year that the South sent a black representative to Congress until contemporary times. By that year, even the federal civil rights statutes themselves had been dismembered and the pieces scattered throughout the U.S. Code. ${ }^{43}$

\section{II}

\section{RaCe LaW in the Age Of DifFerence}

Legal Reconstruction had destroyed the old order. The Reconstruction amendnients made it clear that the freedmen were to be treated as part of the national community and that legal rights and duties could no longer turn explicitly on one's racial status. But, as the example of the Southern

39. GiLMORE, supra note 34, at 121 .

40. J. Morgan Kousser, Colorblind Injustice: Minority Voting Rights and the UNDOING OF THE SECOND RECONSTRUCTION 13 (1999).

41. See, e.g., Guinn v. United States, 238 U.S. 347 (1915) (striking down a "grandfather clause" exempting the descendants of pre-Civil War voters from a literacy test).

42. 170 U.S. 213 (1898); see infra text accompanying note 144.

43. As one commentator recounts:

[I]n 1873 when all federal laws were recodified and published as the Revised Statutes.... [t]he provisions of the civil rights statutes were separated under unrelated chapters of these Revised Statutes and thus lost their distinctive, coherent character. Then in 1894, when the Democrats first won the presidency and both houses of Congress, most of the provisions protecting suffrage were repealed. Still other provisions were dropped in 1909 when the federal criminal laws were recodified.

No effort has ever been made by subsequent Congresses to pick up and repair the broken pieces of civil rights legislation remaining after these wild judicial and legislative forays. All that is left today are a few scattered remnants of a once grandiose scheme to nationalize the fundamental rights of the individual.

Eugene Gressman, The Unhappy History of Civil Rights Legislation, 50 MicH. L. REv. 1323, 1343 (1952) (footnotes omitted). 
Redemption makes clear, many who had learned to exercise power and privilege as "whites" had no intention of relinquishing their claims. Moreover, to all observers race made a difference that was simply incontestable. As Du Bois suggested, the color line would be the problem of the twentieth century. ${ }^{44}$

As a legal matter, the problem of the color line was the problem of reconciling constitutional principles of liberty, equality, and race-neutrality with the drive for white supremacy and eventually white purity. Race law in the first part of the century addressed this problem through the lens of racial difference. Part I.A examines the nature of race discourse at the turn of the century. Part I.B describes some legal means by which egalitarian principles were squared with a renewed commitment to furthering white dominance under the rhetoric of "difference." Part I.C examines how the new focus on racial difference affected the legal regulation of white kinship as well. Part I.D concludes this Part with an overview of the new equilibrium.

\section{A. Civilization and Self-Determination: The Increasing Importance of Race}

At the end of the Civil War, some African Americans and whites had hopes that distinctions based on color would soon fade away altogether, at least in public life. By 1896, however, when Justice Harlan wrote of the great heritage of the white race, the political and legal significance of race had only increased. The Supreme Court found itself the architect of a series of compromises between the new constitutional regime of racial equality and a renewed determination to keep nonwhites away from political and economic power. Meanwhile, between the 1840s and the 1924 Immigration Act, immigrants from Ireland and from southern and eastern Europe poured into the country, causing American elites to wonder just where the boundaries of "whiteness" really lay and whether whiteness was sufficient to become an American. ${ }^{45}$ State and federal legislatures stepped in to control the breeding of "racially unfit" whites and to "Americanize" their children.

The language of race expanded, rather than contracted, following Reconstruction in part because the nation's own political identity had for so long been intertwined with the notion of whiteness. One aspect of race law, of course, involves ascertaining which individuals belong to which racial category: in the United States, these designations were generally made on a decentralized basis by bureaucratic agencies such as the census

44. See supra note 1.

45. See Matthew Frye Jacobson, Whiteness of a Different Color: European IMMIGRANTS AND THE ALChEMY of RACE $43-44$ (1998); see also IAN HANEY Lopez, White By LAW: THE LEgAL CONSTRuCTION OF RACE 37 (1996). 
bureau and hospitals, with the courts stepping in to solve particularly vexed cases. ${ }^{46}$ But race law also had another aspect: the racial categorization of groups as opposed to individuals. This aspect of race law had political and constitutional import. Since the founding of the nation, Congress had tied race to one's fitness for self-government, requiring that its naturalized citizens be "white." Matthew Jacobson argues that the whiteness requirement in the 1790 naturalization law reflected a common strain of eighteenthcentury philosophy, ${ }^{48}$ one that stressed the unique personal qualities required of citizens in a republic. James Madison, for example, whose political vision largely shaped the original Constitution, saw it as necessary (though not sufficient) that the country's rulers should be "men who possess most wisdom to discern, and most virtue to pursue the common good of society." 49 Toward this end, Madison thought that men of property were best suited to govern, and the Constitution was designed to protect the interests of the propertied few over the propertyless many. ${ }^{50}$ More important for our purposes, to be governable, a republic also required that its people hold common habits, traditions, and values, including the capacity to subordinate passion to reason and to make individual sacrifices to the common good. A polity in which the people were "a single organic piece ... with a umitary concern" could not be the heterogeneous body of Anglo-Americans, indigenous peoples, and African slaves that comprised the United States in 1787. Nor did Indians and Negro slaves, as heathens and savages, have the capacities of reason, reflection, and refinement necessary to participate in self-government. ${ }^{52}$ Indeed, even free blacks in the early republic were frequently dismissed by republican whites as lacking these capacities. ${ }^{53}$

46. For example, Ariela Gross, examining nineteenth-century racial determination trials in the South, argues that during the 1850s and 1860s "honor" was a key element of racial identity; white people had honor, and blacks did not. The way one demonstrated this honor was, in turn, partly a function of gender. Gross observes:

[A] white woman's honor lay in the purity of her sexuality, in stark contrast to the degraded sexuality of a black "Jezebel." A white man's honor resided in the public sphere-in his statesmanlike behavior towards superiors and inferiors, his adherence to the gentlemen's code of conduct, his mastery of slaves, and his exercise of citizenship. For a man, performing whiteness meant the performance of rights and privileges. For a woman, performing whiteness meant acting out purity and moral virtue.

Ariela J. Gross, Litigating Whiteness: Trials of Racial Determination in the Nineteenth-Century South, 108 YALE L.J. 109, 157 (1998).

47. See generally HANEY LOPEZ, supra note 45.

48. See JACOBSON, supra note 45 , at 26-28.

49. The Federalist No. 57 (James Madison).

50. See Jennifer Nedelsky, Private Property and the Limits of American Constitutionalism: The Madison Framework and ITs Legacy 50-51, 145-47 (1990).

51. Gordon S. WoOd, The Creation of THe AMerican Republic, I776-1787 at 58 (1969).

52. See JACOBSON, supra note 45 , at $26-27$.

53. See id. at 29. This view of blacks, free or slaves, as not included in "We, the People" and not intended to be included would later be memorialized in Justice Taney's opinion in the Dred Scott case. In contrast, Taney in that opinion described Indians as a "free and independent people" capable of 
By the late nineteenth century, the connection between whiteness and the ability to be part of the American body politic had been underscored by race scientists, some working from the humanist traditions of history and philosophy, and others working in the new fields of natural history opened up by Charles Darwin and others. The popular social language of "civilization" reflected the convergence of popularized theories of evolution and race. Historian Gail Bederman argues, for example:

In the context of the late nineteenth century's popularized Darwinism, civilization was seen as an explicitly racial concept. It meant more than simply "the west" or "industrially advanced societies." Civilization denoted a precise stage in human racial evolution-the one following the more primitive stages of "savagery" and "barbarism." Human races were assumed to evolve from simple savagery, through violent barbarism, to advanced and valuable civilization. But only white races had, as yet, evolved to the civilized stage. In fact, people sonietimes spoke of civilization as if it were itself a racial trait, inherited by all Anglo-Saxons and other "advanced" white races. ${ }^{54}$

Historians and political scientists more precisely connected fitness for government with race by suggesting that democratic institutions and the love of liberty were the special possessions of the white race. In the midnineteenth century, for example, English and American historians and political scientists began to consider with mounting enthusiasm the theory that modern institutions of government and ideals of liberty had come from Anglo-Saxon and Teutonic ancestors. The American historian Herbert Baxter Adams compared the institutions and customs of colonial New England with those described in Tacitus' Germania, and concluded that "[t]he early American system of individual allotment of land, the system of communal pasturage, the duties of certain town officials, the methods of building blockhouses and spiked barricades" could all be traced back to the Teutons. ${ }^{55}$ Adams also argued that the cruelty of the Puritans toward Indians and their own criminals was due to their Saxon nature, and thus should not be too harshly condemned. ${ }^{56}$ John W. Burgess, a political

joining the American body politic on an individual, case-by-case basis. See Dred Scott v. Sandford, 60 U.S. (16 How.) 393, 403-04 (1856).

54. Gail Bederman, MANLiness \& Civilization 25 (1995) (footnote omittcd).

55. Thomas F. Gossett, RaCE: The History of AN IDEA IN AMERICA 107 (1997).

56. As Thomas Gossett summarizes his argument:

We can see modern survivals of such practices in the institutions of "convict labor, southern chain-gangs, and Delaware whipping-posts." We must not criticize too severely either the cruelty of the Puritans or that of their modern descendants. "It is folly to heap reproaches upon the Pilgrim Fathers," said Adams. "We Americans whether in the North or at the South, are of the same English blood; we have inherited kindred institutions, with much the same virtues and about the same vices."

Id. at 108.

One of Adams's students at Johns Hopkins was Thomas Dixon, author of such influential racist novels as The Leopard's Spots: A Romance of the White Man's Burden, 1865-1900 (1903), and the sequel, 
scientist at Columbia, argued that only the Teutonic races had the ability to maintain stable governments, and that it was therefore their duty to rule, ousting lesser races if necessary. ${ }^{57}$ Other historians focused more narrowly on Anglo-American legal institutions as the result of racial heritage. Henry Adams of Harvard, for example, argued that it was not the idea of a parliament that the Teutons and Anglo-Saxons had passed on to their descendants, as others had argued; it was the rule of law itself. ${ }^{58}$

Around the turn of the twentieth century, however, that branch of the white race governing the United States faced a crisis in both foreign and domestic policy. In terms of foreign policy, the turn of the century marked the beginning of a new period of American expansionisni. For commentators such as Henry Cabot Lodge, senator from Massachusetts, and the evangelist Josiah Strong, "[n]ational honor, power, and profits as well as racial fitness and pride were the watchwords." ${ }^{59}$ America now considered itself an ally and racial brother to Britain; Britain's mighty empire would now be joined and perhaps even eclipsed by that of the United States. ${ }^{60}$

But this potential ascendancy was challenged by the Irish, Italians, Slovaks, Jews, Armenians, and Poles who were pouring into the country. These immigrants represented a racial threat both similar to and distinct from the threat posed by Chinese, Indians, and Negroes. The new immigrants were clearly "white" when contrasted with these latter three groups; but, were they white enough? Would they, for example, weaken or

The Clansman: An Historical Romance of the Ku Klux Klan (1905). The Clansman was later made into one of the most celebrated American films of all time: The Birth of a Nation. See Gilmore, supra note 34 , at 67 .

57. As Gossett describes Burgess's argument:

This talent of the Teutonic races, this ability to form stable governments even in countries where they were a minority, involves them in a tremendous responsibility. They must recognize that the talent for organization belongs to them alone. While it is unjust to withhold participation in the government in nations composed of Teutonic elements, it is not wrong elsewhere. Other races must necessarily "remain in a state of barbarism or semi-barbarism, unless the political nations undertake the work of state organization for them." The civilized state thus "may righteously go still further than the exercise of force in imposing organization. If the barbaric populations resist the same, a l'outrance, the civilized state may clear the territory of their presence and make it the abode of civilized man." Above all, the dominant Teuton power "should not be troubled in its conscience about the morality of this policy when it becomes manifestly necessary." There is far too much "weak sentimentality abroad in the world" on this subject and it springs mainly from a "lack of discrimination in regard to the capacities of races."

GosSETT, supra note 55, at 113 .

58. See id. at 105-06.

59. Michael H. Hunt, Ideology and U.S. Foreign Policy 37 (1987).

60. Political scientist Michael Hunt describes the thinking:

By the standards of industrial progress, military prowess, and international influence and control, Anglo-Saxons had an incontestable claim to the top of the racial heap. From that eminence they would point the way toward an era of unprecedented world peace and prosperity. Lesser races, awed and grateful, could follow the lead of the Anglo-Saxon-or drop to the bottom of the heap to meet their fate, ultimate extinction.

1d. at 79. 
strengthen the nation as it began to take a newly aggressive role in foreign relations? The frontier had been declared closed; the great adventure of Indian-killing was over. By becoming decadent, weak, and unmanly, great races and nations could fall as well as rise. New challenges were needed if the white race in the United States was to avoid flabbiness, corruption from within, and decay. ${ }^{61}$

Domestic policy, as well, required attention to the race question. The explosion of a polyglot, often desperately poor, immigrant population from countries far away from England and Northwest Europe raised doubts about whether whiteness alone was sufficient for political selfdetermination, or whether Anglo-Saxon or Teutonic heritage was further required. Could America assimilate these newcomers whose level of civilization seemed distinctly below that of the Englishman or the Teuton? Some intellectuals began building racial hierarchies within the category of "whiteness" itself.

Whiteness during this period, then, was both a social status and a behavioral norm. Whiteness, and increasingly, "Anglo-Saxonness," marked an elite who saw themselves as "native Americans," entitled to political, economic, and social dominance. At the same time, "whiteness" and its cognate concepts stood for an ideal of civilization to which all humans, but especially Americans, should aspire: the capacity for self-government, a love of liberty, and a commitment to democratic institutions and the rule of law. Some groups might be nonwhite by status, yet have the capacity to assimilate to whiteness as norm. Conversely, some groups that were white by status might prove to be unable or unwilling to fulfill their potential.

In this way, racial thinking did not fade away but rather intensified in the new century. American race law had previously been concerned for the most part with keeping nonwhites out of the political body of "we the people" while exploiting their land and labor. In the new century things were considerably more complex. Efforts to keep African Americans and other uncontestably nonwhite citizens now needed to be reconciled with

61. It was in this spirit that Theodore Roosevelt, flush with exhilaration from his participation in the Indian wars, exhorted his listeners to seize the day in his speech before the Hamilton Club in April 1899, "The Strenuous Life." Theodore Roosevelt, The Strenuous Life, in The Strenuous LIFE: ESSAYS AND ADDRESSES 3-4 (1900). The previous year, President William McKinley had entered into war with Spain to "free Cuba." According to Hunt:

[McKinley then] quickly put through Congress the long-delayed annexation of Hawaii and ordered American forces to occupy Cuba, Puerto Rico, Guam, and the Philippines. He followed in 1899 with fresh initiatives: the passage of a treaty annexing the latter three islands and the conclusion of an agreement with Germany on the partition of Samoa. That same year he oversaw the dispatch of the open-door notes in response to a feared partition of China and in 1900 sent troops to help put down the Boxers.

HUNT, supra note 59, at 38 . These actions met with heated opposition from those who saw democracy threatened by the prospect of empire. Roosevelt, however, strongly approved of McKinley's actions; he urged his audience to support the United States' imperialist adventures by linking them with moral fiber and racial destiny. 
the norm of racial equality. Meanwhile, race law itself expanded, first to reach those new immigrant groups whose claims to whiteness were debatable, and finally to those who were unquestionably white as the idea of whiteness itself took on a biological cast. Racial difference was finally everywhere; the color line would eventually be driven through the white race itself.

\section{B. Race Law and Nonwhite Subjects in the Age of Difference}

How could the new constitutional principle of racial equality be squared with calls to further the progress of civilization around the world and the fulfillment of the destimy of the white race? American race law at the beginning of the twentieth century divided into two tributaries. Outside the realm of equality, elites continued to use state power to restrict the rights of nonwhites based on their racial status. Within those boundaries, equality was reconciled with the denıands for white supremacy and purity under a new rubric of racial "difference."

\section{Plenary Power and Nonwhite Citizens: Beyond the Scope of Equality}

The Reconstruction constitutional revolution did not alter the conviction in Congress and state legislatures that the United States did or should belong to the white race. In the last decades of the nineteenth century and the first decades of the twentieth, the United States operated on blatantly racist principles of exclusion and annexation in its foreign relations (and its quasi-foreign relations with Indians). Nativist racism against peoples perceived to be nonwhite, moreover, met little or no legal resistance as long as its targets were not American citizens. Indeed, the Supreme Court gave license to nativist racism by developing doctrines of congressional "plenary power" that restricted the possibility of judicial review over racist legislative actions.

Outside the sphere of equality, then, state race law continued its preReconstruction function of facilitating the exclusion and exploitation of nonwhite peoples. Perhaps the most obvious example is the Supreme Court's doctrine that Congress's power to expel or exclude aliens is not subject to judicial review. ${ }^{62}$ The foundation of this plenary power over immigration is found in two cases decided on the cusp of the twentieth century: Chae Chan Ping v. United States ${ }^{63}$ (also popularly known as the Chinese Exclusion Case) and Fong Yue Ting $v$. United States. ${ }^{64}$ Both cases considered the validity of the federal Chinese Exclusion Act of 1882; both

62. See generally Gabriel J. Chin, Segregation's Last Stronghold: Race Discrimination and the Constitutional Law of Immigration, 46 UCLA L. REV. 1 (1998).

63. 130 U.S. 581 (1889).

64. 149 U.S. 698 (1893). 
opinions gave deference to a statute that prohibited Chinese people from entering the United States on unmistakably racial grounds.

The Exclusion Act was, in a sense, a response to Reconstruction. In the second half of the nineteenth century, immigration from China to the American West had surged. Though Chinese immigrants were initially welcomed to the West and lauded as hardworking, respectable people (unlike Mexicans and Indians, who were widely disparaged as lazy), by 1852 the Chinese had emerged as the prime targets of a nativist frenzy based on the perception of economic and cultural threat.

Both the California legislature and the California courts became leaders in government attempts to exclude and discriminate against the Chinese. ${ }^{65}$ California's legal oppression of the Chinese culminated in the state constitutional convention of 1878 , the express purpose of which was to write anti-Chinese provisions into the constitution. In accordance with this agenda, California had refused to ratify the Reconstruction amendments, but they had nevertheless become binding on the state through the Supremacy Clause, as had the federal civil rights statutes still in force. The problem, then, was how to adequately exclude and subordinate the Chinese in light of the new federal mandate of racial equality. ${ }^{66}$

65. Local governments also participated in the attempt to subordinate the Chinese. See, e.g., William J. Courtney, San Francisco's ANTi-Chinese Ordinances, 1850-1900 passiin (1956) (describing ordinances passed by the city of San Francisco that, among other things, prevented "Chinese or Mongolians" from doing work for the city in Yerba Buena Park; that made it illegal to "carry a basket or baskets, bag or bags, suspended from or attached to poles across or upon the shoulder"; that made it illegal to discharge fireworks in Chinatown (an attack on Chinese New Year celebrations); and that forbade the ringing of gongs during theatrical performances (a witness to the Joint Congressional Committee in October 1876 explained, "It would not be a Chinese play if it had no gongs.")).

The white-dominated labor movement was the source of some of San Francisco's anti-Chinese ordinances. In an early manifestation of affirmative aetion, for example, "In July, 1875 the proprietors of a shirt factory, which would employ about 400 persons, wcre issued a boiler permit on the condition that they employ not more than 150 Chinese, and decrease that number each quarter until the entire employment force was white." $1 d$. at 58 .

66. The proposals that initially emerged from the 1878 state constitutional convention included banning Chinese immigrants to the state, whether from China or from other states; making it illegal for Chinese to work in certain industries and to be employed "on any State, county, municipal, or other public work"; making it illegal for Chinese to catch fish in government waters or to be granted any license to pursue "any business, trade, or occupation in this State"; causing any corporation that employed Chinese people to lose its franchise and all legal rights, and denying individual employers of Chinese people the right to vote; and forbidding Chinese people the right "to purchase, own, or lease real property" in the state. RINGER, supra note 11, at 590-92 (1983) (quoting 1 California Constitutional Convention of 1878-79, Debates and Proceedings, 627-28)). However, concerns over the legality of these proposals in light of federal civil rights laws and federal power over immigration whittlcd down some of the wilder proposals. Others became law but were struck down by the courts on constitutional grounds or on grounds of inconsistency with the Burlingame Trcaty with China within a few years of their passage. See id. at 598-99. The Supreme Court, for example, would uphold the constitutional rights of the Chinese in Yick Wo v. Hopkins, 118 U.S. 356 (1886) (holding that a San Francisco ordinance regulating laundries that was faeially neutral but in fact was enforced only against Chinese people violated the Fourteenth Amendment). 
Failing at their state attempts to exclude the Chinese, California officials began to look to the federal government for help. Congress had initially been reluctant to legislate against the Chinese in America based on foreign policy concerns about U.S.-China relations; indeed, the Burlingame Treaty of 1865 required that Chinese subjects visiting or residing in the United States receive the same "privileges, immunities, and exceptions" as citizens of the most favored nation. ${ }^{67}$ By 1882 , however, the insistence of the western states had become overwhelming. Although critics voiced fears of economic competition, the principal reason for Chinese exclusion was the argument that the Chinese were culturally distinct, inferior, unassimilable, and potentially degrading to white society and the white race. As Senator Saulsbury stated in the debate over the first Exclusion Act:

I would not close the gates against the immigration of the Chinese to this country simply upon the ground that they enter into competition with labor, but I put it upon another ground, which is that it introduces a distinct race of people with a different civilization to that which we are accustomed, wholly incapable of assimilation with our people. In my opinion, their presence among us will not improve their condition morally or in any other respect ... while it may lead to discord and possible collision with the Anglo-Saxon race among whom they live. ${ }^{68}$

Indeed, it was not so much hatred of the Chinese as fear for the white race that took center stage. As Senator Miller of California, arguing for the bill, opined:

History teaches no lesson with greater clearness or persistence than this; that nations once powerful have degenerated and gone into decay, generally, in consequence of, and in proportion to, the admission and incorporation into their bodies-politic of inferior or heterogeneous races; and this we may apply with peculiar fitness to a nation like ours, whose government is a government of the people. Debase the people and you degrade your sovereign ....

[To preserve the] American Anglo-Saxon civilization without contamination or adulteration with any other this bill must be passed, [its provisions enforced] to the letter.... China for the

67. 16 Stat. 739 (1868).

68. 13 CoNG. Rec. 1584 (1882) (statement of Sen. Saulsbury). For a fuller discussion of the role of race in the legislative debates over the Exclusion Acts, see generally Chin, supra note 62, at 22-37. Chin notes that during these debates, legislators explicitly compared Chinese with African Americans. Opponents of restriction argued for adherence to the principles of equality for African Americans upon which Reconstruction had been founded; proponents of restriction concluded that the AfricanAmerican experiment had been a failure. See id. at 33-36 (quoting congressional debates about the problems posed by African Americans and by Chinese immigrants). 
Chinese! California for Americans and those who will become Americans! ${ }^{69}$

After an initial presidential veto on grounds of conflict with the Burlingame Treaty, Congress passed a bill suspending further Chinese immigration for ten years, requiring Chinese persons already in the United States to register with a customs house in America before leaving the country, and requiring Chinese eligible to enter the United States to carry a certificate with pertinent facts about themselves attached to it in English. ${ }^{70}$ This bill passed into law in 1882 as the Chinese Exclusion Act, and was followed in 1888 by the Scott Act, ${ }^{71}$ which made it unlawful for any Chinese laborer to depart the United States and subsequently return, with or without a certificate.

Chae Chan Ping was a legal resident of the United States who had lived in San Francisco for over a decade. He was returning home after an overseas trip with a reentry certificate issued by the collector of customs of the Port of San Francisco when the Scott Act voided all such reentry certificates with immediate effect. Despite the fact that the Act seemed clearly to contravene two treaties between the United States and China, the Court upheld Ping's exclusion in the Chinese Exclusion Case. ${ }^{72}$ In its opinion, the Court located the power to regulate immigration solely in the federal government:

To preserve its independence, and give security against foreign aggression and encroachment, is the highest duty of every nation, and to attain these ends nearly all other considerations are to be subordinated. It matters not in what form such aggression and encroachment come, whether from the foreign nation acting in its national character, or from vast hordes of its people crowding in upon us. ${ }^{73}$

The Court's sweeping language suggested that in Ping's case, the determination of Congress was "conclusive upon the judiciary." The case has come to stand both for the proposition that the courts will give effect to an act of Congress that is inconsistent with a prior treaty, and the notion that Congress has nearly unlimited power over immigration. ${ }^{75}$

Four years later, over a strong dissent, the Court held further that Congress may expel aliens lawfully present in the United States in Fong 47.

69. 47(1) CONG. REC. 1882 (statement of Sen. Miller), quoted in RiNGER, supra note 11, at 646-

70. Chinese Exclusion Act, 22 Stat. 58 (1882).

71. 25 Stat. 504 (1888).

72. Chae Chan Ping v. United States, 130 U.S. 581 (1889).

73. Id. at 606 .

74. Id.

75. See Louis Henkin, The Constitution and United States Sovereignty: A Century of Chinese Exelusion and Its Progeny, 100 HARv. L. REv. 853, 863 (1987). 
Yue Ting v. United States. ${ }^{76}$ According to the majority, "[t]he right of a nation to expel or deport foreigners, who have not been naturalized, or taken any steps towards becoming citizens of the country, rests upon the same grounds, and is as absolute and unqualified as the right to prohibit and prevent their entrance." 77

This grant of plenary power meant that Congress need not provide any legal protections for aliens. Congress need not provide any particular procedures for deciding whom to admit to the United States. Immigration authorities might exclude a returning alien without a hearing and on the basis of undisclosed evidence; and, "if the alien could not be deported because no country would receive him, he could be detained indefinitely." "78 Above all, the finding of "plenary power" in Congress over matters of immigration granted Congress the power to use race as the basis for exclusion. By 1917, the American nativist fear of being overrun by Asians culminated in the creation of an "Asiatic Barred Zone," completely excluding from admission into the United States all aliens from India, Burma, Thailand, the Malay States, the East Indian Islands, Asiatic Russia, the Polynesian Islands, and part of Arabia and Afghanistan. ${ }^{79}$

Nativist racism against Asians in the United States was expressed in naturalization law as well as in immigration restrictions. As we have already seen, the federal naturalization act of 1790 limited naturalization to "free white persons. ${ }^{.80}$ In 1870, at the height of Reconstruction, Senator Charles Sumner of Massachusetts had introduced an amendment that read in part: "That all acts of Congress relating to naturalization be, and the same are hereby, amended by striking out the word 'white' wherever it occurs, so that in naturalization there shall be no distinction of race or color." ${ }^{\text {"81 }}$ Anti-Chinese forces, however, greeted Sumner's proposal with dismay and outrage, raising the specter of a yellow horde overwhelming the Anglo-Saxon institutions and ideals of the United States, and

76. 149 U.S. 698 (1893).

77. 149 U.S. at 707. Justice Field, who had supported the majority opinion in Chae Chan Ping, wrote the dissent in Fong Yue Ting. In Field's view,

Aliens from countries at peace with us, domiciled within our country by its consent, are entitled to all the guaranties for the protection of their persons and property which are secured to native-born citizens.... To hold that they are subject to any different law, or are less protected in any particular, than other persons, is, in my judgment, to ignore the teachings of our history, the practice of our government, and the language of our constitution. Id. at 754 .

78. Henkin, supra note 75, at 860 (discussing United States ex rel. Knauff v. Shaughnessy, 338 U.S. 537 (1950) and Shaughnessy v. United States ex rel. Mezei, 345 U.S. 206 (1953)). In recent years, the doctrine of plenary power over immigration has meant that "detaining thousands of undocumented Cubans for several years does not deprive them of liberty without due process of law," and that refugees on the high seas suspected of fleeing Haiti for the United States without proper documents may be forcibly seized by U.S. officials and returned to Haiti. Id., supra note 75, at 861-62.

79. See Immigration Act, 39 Stat. 874 (Feb. 5, 1917).

80. Act of March 26, 1790, ch.3, 1 Stat. 103.

81. 41 Cong. Globe 41 st Cong., 2nd Sess. 5121 (1870). 
expressing fears of unfair competition from "coolie labor."82 The final result was a compromise: the privilege of naturalization would be extended to "aliens of African nativity and to persons of African descent," but to no one else. From 1878 until the end of explicit racial restrictions on immigration in 1952, the courts were faced with the task of determining who was "white" and therefore eligible for naturalization. ${ }^{83}$ The early-twentiethcentury cases, not surprisingly, held that Asians were not white. ${ }^{84}$

The doctrine of plenary power over immigration, coupled with federal law barring Asians from naturalization, placed Asian immigrants in a distinctive position within American race law in the first half of the twentieth century. To the extent that Asian immigrants were not citizens, but remained "aliens not eligible for citizenship," they were vulnerable not only to exclusion altogether but to discrimination by states as well as by the federal government. ${ }^{85}$ To the extent that the descendants of such

82. RINGER, supra note 11 , at 628 . "Coolie labor" referred to "the widely held belief that the mass of the Chinese immigrants were bound to long contracts of indentured servitude ... and that in some cases their families in China were held hostage to the faithful performance of these contracts." MCCLAIN, supra note 26, at 11; see also RINGER, supra note 11, at 602-03 (discussing the reccived notion of "coolie labor").

83. See generally HANEY LOPEZ, supra note 45. Haney Lopez notes, interestingly, that none of the persons attempting to be naturalized under this statute claimed to be of African descent; all aspired to "whiteness." Id. at 49-50.

84. The first case to reach the courts was that of Ah Yup, a Chinese immigrant, and after much discussion, the court held that Chinese persons were not white. See In re Ah Yup, 1 F.Cas. 223, 224 (C.C.D.Cal. 1878). The result was the same for Gee Hop, who had initially secured naturalization in 1890 , only to be refused permission to reenter the United States after a trip to China on authority of the Chinese Exclusion Act. See In re Gee Hop, 71 F. 274 (N.D. Cal. 1895). People from other Asian countries were similarly denied the privilege of naturalization on the basis of their nonwhiteness: Burmese, see In re Po, 28 N.Y.S. 883 (1894); Japanese, see Ozawa v. United States, 260 U.S. 178 (1922); In re Saito, 62 F. 126 (C.C.D.Mass. 1894); Filipinos, see In re Mallari, 239 F. 416 (D.Mass. 1916); Koreans, see Petition of Easurk Emsen Charr, 273 F. 207 (W.D.Mo. 1921); and finally, after several contrary holdings, Indians from the Asian subcontincnt, see United States v. Thind, 261 U.S. 204 (1923). The confusion over the racial status of subcontinental Indians stemmed from initial judicial reliance on the science of ethnology, which classified certain groups of subcontinental Indians as "Caucasians." In the end, Thind's case was definitive in pushing the Supreme Court to a "common knowledge" test for whiteness that relied not on science but on the social norms of undisputedly "white" people. For a fuller discussion of Thind and the turn from science to "common knowledge," see HANEY LOPEZ, supra note 45, at 86-102.

85. For example, in the early part of the twentieth century, the West adapted to the postReconstruction legal-racial regime by passing "Alien Land Laws." These statutes prohibited "aliens not eligible for citizenship"-that is, Asian Americans, primarily Japanese Americans-from owning property. Touted by white small farmers who pleaded for an economic monopoly in the name of white racial purity, the laws were intended to push Japanese farmers out of the production of strawberrics, sugar beets, green vegetables, and fruits and nuts, where they had begun to make a comfortable living. See RINGER, supra note 11, at 726-55; RonAld TAKAKI, A DifFerent MirRoR: A History OF Multicultural AMERICA 268-73 (1993).

The Supreme Court, noting that the Fourteenth Amendment did not apply to aliens, upheld Washington state's alien land law in Terrace v. Thompson, 263 U.S. 197 (1923), commenting sagely that "the State has wide discretion in determining its own public poliey and what measures are necessary for its own protection and properly to promote the safety, peace and good ordcr of its people." 263 U.S. at 217 . The opinion below was less civil in tone. Judge Cushman for the Washington 
immigrants were birthright American citizens ${ }^{86}$ they were formally protected by the Constitution; yet, as we will see, they found themselves subjected to the same kind of caste racism that African Americans experienced. Meanwhile, painted as perpetual "foreigners" threatening to overrun the West, Asian Americans have continued to be a population vulnerable to expressions of nativist hysteria. The most horrifying example, of course, is the wholesale imternment of Japanese citizens, and the confiscation of their land and property, during World War II, an action upheld by the Supreme Court against constitutional attack. ${ }^{87}$

Congressional plenary power over immigration, and the shield this power provides against equality norms, has also aided in the continuing economic exploitation of Mexicans and Mexican Americans in the United States. Socially despised as "greasers" and often confined to segregated neighborhoods and segregated schools throughout the West, Mexicans and Mexican Americans were nevertheless valuable to corporate agricultural concerns throughout the twentieth century: agriculturists could import young, unattached men from Mexico when crops needed harvesting and deport them again when their services were no longer necessary. Moreover, the threat of deportation rendered undocumented residents particularly docile: employers need not fear unions or other collective or individual demands for higher wages and better working conditions as long as they could easily throw out and replace the troubleniakers and their followers. Unlike China, Mexico was close by, and not sought as a trading partner or political ally; and for its own reasons, the Mexican government often sanctioned the siphoning off of its unskilled workers. Thus, Congress periodically passed statutes aiding agricultural employers in securing a Mexican work force. ${ }^{88}$ Later in the century, agricultural workers-along

Supreme Court had candidly justified the statute in terms of protecting America for the white race; the court's duty, the judge explained, "is to hold impregnable the barrier erected by Congress to preserve, in its purity, our own type of civilization. The more homogenous its parts, the more perfect the union." Cited in RINGER, supra note 11 , at 753. In another ruling handed down the same day as Terrace, the Court upheld California's alien land law in Porterfield v. Webb, 263 U.S. 225 (1923).

The state's power to push aliens out of the legal economy was not constitutionally unlimited, however. In Webb y. O'Brien, 263 U.S. 313 (1923), the Court held that a scheme under which a Japanese alien was employed by a white citizen in a kind of sharecropping arrangement was more than a contract of employment, but constituted a transfer of interest in land that could be banned by California's alien land law. However, Justice Butler, writing for the Court, warned that a denial of the right to make such cropper contracts "does not deny the ordimary means of earning a livelihood or the right to work for a living." 263 U.S. at 324. Thus, the Court suggested in dictum, the state could not constitutionally deny aliens ineligible for citizenship the right to sell their labor-only the right to amass property and capital. See also Terrace v. Thompson, 263 U.S. 197 (1923).

86. See United States v. Wong Kim Ark, 169 U.S. 649, 664 (1898).

87. See Korematsu v. United States, 323 U.S. 214 (1944); Hirabayashi v. United States, 320 U.S. 81 (1943).

88. For a fuller account of these statutes, see generally Gilbert Paul Carrasco, Latinos in the United States: Invitation and Exile, in Immigrants Out! The New Nativism and the ANtIImMigrant IMPUlse in the United States 190, 190-200 (Juan F. Perea ed., 1997). 
with domestic workers who were also predominantly people of colorwould be exempted from New Deal worker protections. ${ }^{89}$ Congress's plenary power over immigration law helped preserve and further white dominance by providing a docile Mexican work force at the bottom of the economic ladder.

Unlike the immigration power, the power to regulate commerce with Indian tribes is specifically delegated to Congress in the Constitution. The founding decisions of Indian law, crafted by Justice John Marshall, started from the recognition that it was for the United States as a sovereign power-not "the courts of this country," and not the individual states-to determine land rights, to make treaties, and to regulate Indian affairs. ${ }^{90}$ It was only at the beginning of the twentieth century, however, that the Supreme Court elaborated the notion that such power is "plenary"; neither subject to judicial scrutiny nor limited by treaties.

In United States $v$. Kagama,${ }^{91}$ the Court searched for a constitutional source for the Major Crimes Act of 1885, which made it a federal offense for one Indian to commit certain crimes against the person or property of another. Congress had purported to find sufficient authority in the Commerce Clause. A reader familiar with the civil rights cases decided in the same period might be tempted to guess that the Court would hold, based on principles of federalism, that Congress had overstepped its constitutional bounds. Indeed, the Court's opinion expresses initial skepticism, calling the Commerce Clause argument a "strained construction" of the Constitution. Yet the Court held that Congress had the power to pass the statute, after assuring itself and its audience that the statute "does not interfere with the process of the state courts within the reservation, nor with the operation of state laws upon white people found there." 92

The decision in Kagama was the beginning of a series of cases expanding congressional power over internal Indian affairs. In 1913, the Court overruled the decision of a federal district court that had held

89. See generally Marc Lindner, Farm Workers and the Fair Labor Standards Act: Racial Discrimination in the New Deal, 65 TEx. L. REv. 1335 (1987) (arguing that in order to secure southern support for New Deal legislation, President Roosevelt and his allies exempted farmworkers from protection, thereby preserving the racialized plantation system in the South).

90. See, e.g. , Johnson v. McIntosh, 21 U.S. (8 Wheat.) 543, 589, 591 (1823) (The "courts of this country" have no authority to reject the conversion of "discovery of an inhabited country into conquest ... if the property of the great mass of the community originates in it ...."); Worcester v. Georgia, 31 U.S. (6 Pet.) 515, 561 (1832)(holdjng the state of Georgia has no authority to interfere with relations established between the United States and the Cherokee nation, the rcgulation of which are vested exclusively in the federal government); Cherokee Nation v. Georgia, 20 U.S. (5 Pet.) 1, 19 (1831) (holding that the Court had no Article III jurisdiction to hear the case because the Cherokees are not a "foreign nation[]"). For this reason, Nell Newton has commented that "[t]he mystique of plenary power has pervaded federal regulation of Indian affairs from the beginning." Nell Jessup Newton, Federal Power Over Indians: Its Sources, Scope, and Limitations, 132 U. PA. L. REv. 195, 199 (1984).

91. 118 U.S. 375 (1886).

92. Id. at 378,383 . 
inapplicable to New Mexico Pueblos a federal law making it a crime to introduce intoxicating liquor into Indian country. ${ }^{93}$ The technical question was whether the Pueblo lands were "Indian country" since, rather than being owned by the federal government like reservation land, the Pueblo lands were collectively held in fee simple by the Pueblos under grants fron the Spanish government later confirmed by Congress. The Court brushed aside the fee simple nature of the title, because it was "a communal title, no individual owning any separate tract." ${ }^{\text {" }}$ Rather, the Court focused on the character of the Pueblos theniselves:

The people of the pueblos, although sedentary rather than noinadic in their inclinations, and disposed to peace and industry, are nevertheless Indians in race, custonis, and domestic government. Always living in separate and isolated communities, adhering to primitive modes of life, largely influenced by superstition and fetichisn, and chiefly governed according to the crude customs inherited from their ancestors, they are essentially a simple, uninformed and inferior people. ${ }^{95}$

This racial character, and the relationship of dependence upon the federal government it necessitated, signaled the existence of a plenary power in Congress to shoulder the white inan's burden:

Not only does the Constitution expressly authorize Congress to regulate commerce with the Indian tribes, but long continued legislative and executive usage and an unbroken current of judicial decisions have attributed to the United States as a superior and civilized nation the power and the duty of exercising a fostering care and protection over all dependent Indian communities within its borders, whether within its original territory or territory subsequently acquired, and whether within or without the limits of a State. ... It is for [Congress], and not the courts, to determine when the true interests of the Indian require his release from such condition of tutelage. ${ }^{96}$

93. See United States v. Sandoval, 231 U.S. 28 (1913).

94. Id. at 48 .

95. Id. at 39. Commentators David Getches and Charles Wilkinson note that this decision officially changed the racial status of the Pueblo Indians, who, in 1869, the Territorial Court of New Mexico had determined were not "savages" like other Indian peoples, but rather some of "the most law-abiding, sober, and industrious people of New Mexico." DAvid H. Getches \& CharLes F. Wilkinson, CASES AND MATERIals ON FEDERAL INDIAN LAw 199 (2d ed. 1986) (quoting United States v. Lucero, 1 N.M. 422, 444-45 (1869)).

96. Sandoval, 231 U.S. at $45-46$ (citation omitted). The Court hastily followed up this account of nearly absolute power in Congress with the qualification:

Of course, it is not meant by this that Congress may bring a community or body of people within the range of this power by arbitrarily calling them an Indian tribe, but only that in respect of distinctly Indian communities the questions whether, to what extent, and for what time they shall be recognized and dealt with as dependent tribes requiring the guardianship and protection of the United States are to be determined by Congress, and not by the courts. Id. at 46 (emphasis added). Thus, white men were safe from this plenary power; the pivotal question would be the racial question of whether the people being so governed were "distinctly Indian." 
Finally, in Lone Wolf $v$. Hitchcock ${ }^{97}$ the Court brushed aside a valid treaty signed with the United States in the name of congressional plenary power. The Court in that case held that Congress has the power to abrogate Indian treaties, and that this power is not subject to judicial scrutiny at all: "Plenary authority over the tribal relations of the Indians has been exercised by Congress from the beginning, and the power has always been deemed a political one, not subject to be controlled by the judicial department of the government." ${ }^{\text {98 }}$ Citing the Chinese Exclusion Case, the Lone Wolf Court concluded, "[A]s with treaties made with foreign nations, the legislative power might pass laws in conflict with treaties made with the Indians." ${ }^{\prime 99}$

Plenary power over matters of immigration and naturalization permitted Congress to foster the white character of the American polity, while the distinction between alien and citizen provided a formally race-neutral basis for state and local discrimination with a similar aim. In the realm of Indian law, the doctrine of congressional plenary power served partially to protect Indians from imcursions by the states eager to take control of Indian lands and resources; but the doctrine also left Indians with little judicial protection from federal disregard of treaties and federal attempts to "civilize" an inferior race. In each of these areas of law, race figured heavily in determining the scope of legal rights; yet this branch of race law was untouched by the norm of racial equality.

Finally, as the twentieth century began, the Supreme Court found plenary power in Congress to control access to citizenship and the exercise of constitutional rights by nonwhite peoples in foreign countries where the Umited States enjoyed political control. For example, in a series of cases called the "Insular Cases," 100 decided at the turn of the century, the

97. 187 U.S. 553 (1903).

98. Id. at 565. This plenary power, in the Court's view, made a judicial consideration of the merits impossible:

[W]e may not specially consider the contentions pressed upon our notice that the signing by the Indians of [an agreement providing for the allotment of tribal land] was obtained by fraudulent misrepresentations, and concealment, that the requisite three fourths of adult male Indians had not signed, as required by the ... treaty ... since all these matters, in any event, were solely within the domain of the legislative authority, and its action is conclusive upon the courts.

... We must presume that Congress acted in perfect good faith in the dealings with the Indians of which complaint is made, and that the legislative branch of the government exercised its best judgment in the premises. In any event, as Congress possessed full power in the matter, the judiciary cannot question or inquire into the motives which prompted the enactment of [the] legislation. If injury was occasioned, which we do not wish to be understood as implying, by the use made by Congress of its power, relief must be sought by an appeal to that body for redress and not to the courts.

Id. at 567-68.

99. Id. at 566 (citation omitted).

100. See, e.g., De Lima v. Bidwell, 182 U.S. 1 (1901); Goetze v. United States, 182 U.S. 221 (1901); Dooley v. United States, 182 U.S. 222 (1901); Armstrong v. United States, 182 U.S. 243 
Supreme Court confronted the question of how to shape a constitutional structure for the colonies that the United States had won in the SpanishAmerican War. ${ }^{101}$ Its approach was to grant "plenary" power to Congress to decide whether and to what extent the Constitution would "follow the flag." 102 It was also an issue that was understood as involving basic questions of race as civilization.

The peculiar legal status of Puerto Rico provides an example. The original bill on Puerto Rico's status described all its inhabitants except those who elected to retain their allegiance to Spain as "citizens of the United States," and provided that the Constitution, as well as "all the laws of the Umited States locally applicable," would have "the same force and effect in the island of Puerto Rico as elsewhere in the United States."103 After several weeks of committee hearings, however, the revised bill identified Puerto Ricans not as U.S. citizens but as "citizens of Porto Rico [sic], and as such entitled to the protection of the United States." 104 The children of the current inhabitants would hold this status as well. Moreover, the new bill deleted all references to the Constitution as the legal framework for the island, providing instead that "the statutory laws of the United States not locally inapplicable" would apply. ${ }^{105}$

What accounted for the change? In crafting a legal status for Puerto Ricans, members of Congress were mindful of the possible precedent being set for the Philippines, and issues of race and civilization were central to this discussion. ${ }^{106}$ While the inhabitants of Puerto Rico were thought to be mostly "white," with a few "negroes" and "mulattos" mixed in, the racial character of the Philippines struck horror into the hearts of many congressmen. The Filipinos, like the Chinese before them, represented both a

(1901); Downes v. Bidwell, 182 U.S. 244 (1901); Huus v. New York and Porto Rico S.S. Co., 182 U.S. 392 (1901).

101. The Spanish-American War left the United States with four holdings secured from Spain: the Philippines, Puerto Rico, Guam, and a portion of Samoa. The Treaty of Paris between the United States and Spain stipulated that "[ $t$ ]he civil rights and political status of the native inhabitants of the territories hereby ceded to the United States shall be determined by the Congress." Treaty of Paris, Dec. 10, 1898, U.S.-Spain, art. IX, cl. 2, 30 Stat. 1759-60. At the same time, the Treaty permitted Spanish subjects in the transferred possessions to elect to retain their Spanish citizenship, thus respecting a distinction between European and indigenous inhabitants. See id.

102. This question mirrored a bitter political debate between those who, like Teddy Roosevelt, celebrated the nation's colonial exploits, and those who decried imperialism as contrary to deinocracy.

103. RINGER, supra note 11 , at $954-55$ (citations omitted).

104. Id. at 957.

105. Id. at 958. Both the Senate and House committees insisted that the organization and government of territories was "not a constitutional right, but solely a question of expediency within the discretion of Congress." Id. at 964 (emphasis omitted). Minority members of the House committee, however, described this "plenary power" position as pure and simple imperialism. See id. at 966.

106. For fuller treatments of the history and current status of Puerto Rico, see Jose A. CABRANES, Citizenship and the American Empire (1979); Ediberto Román, The Alien-Citizen Paradox and Other Consequences of U.S. Colonialism, 26 FLA. ST. U. L. REv. 1 (1998); Ediberto Román, Empire Forgotten: The United States's Colonization of Puerto Rico, 42 VILL. L. REv. 1119 (1997). 
cultural and an economic threat. For example, Representative Thomas Spight, after praising the natives of Puerto Rico, argued, "How different the case of the Philippine Islands, 10,000 miles away. . . . The inhabitants are of wholly different races of people from ours-Asiatics, Malays, negroes and mixed blood. They have nothing in common with us and centuries cannot assimilate them."107 Echoing the rhetoric of "coolie labor" that had previously been used to characterize the Chinese, Representative John Dalzell declared himself unwilling "to see the wage-earner of the United States, the farmer of the United States, put upon a level and brought into competition with the cheap half-slave labor, savage labor, of the Philippine Archipelago." "108 The result of Congress's racial concerns, both about Puerto Rico itself and the dangerous precedent that might be set for the Philippines, was an intermediate limbo-like status for Puerto Rico that was neither purely that of a colony nor fully that of a U.S. state.

Puerto Rico's new, anomalous legal status soon came before the courts. In Downes $v$. Bidwell, ${ }^{109}$ one of the most frequently cited of the Insular Cases, the primary issue was whether the Foraker Act, which singled out Puerto Rico for a fifteen percent duty on items "imported . . . from foreign countries," 110 was constitutional as applied to Puerto Rico in light of Article I, Section 8 of the Constitution, which requires uniformity of duties throughout the United States. ${ }^{111}$ In a plurality opinion in which he spoke only for himself, Justice Brown announced the judgment of the Court that Congress could apply the Foraker Act to Puerto Rico despite the language of Article I. Justice Brown justified this decision in explicitly racial terms. In his view, the plenary power of Congress to determine the reach of the Constitution in territories acquired by purchase or "conquest" was necessary given America's "Manifest Destiny":

We are also of opinion that the power to acquire territory by treaty implies not only the power to govern such territory, but to prescribe upon what terms the United States will receive its inhabitants, and what their status shall be in what Chief Justice Marshall termed the "American Empire." There seems to be no middle ground between this position and the doctrine that if their inhabitants do not become, immediately upon annexation, citizens of the United States, their children thereafter born, whether savages or civilized, are such, and entitled to all the rights, privileges and immunities of citizens. If such be their status, the consequences will be extremely serious. Indeed, it is doubtful if Congress would ever assent to the annexation of territory upon the condition that its inhabitants,

107. 33 CONG. REC. 2105 (February 22, 1900) (statement of Rep. Spight).

108. 33 CONG. REC. 1959 (February 19, 1900) (statement of Rep. Dalzell).

109. 182 U.S. 244 (1901).

110. 31 Stat. 77 (1900) (codified at 48 U.S.C. $\$ \S 733,736,738-40,744,864$ (1994)).

111. See Downes, 182 U.S. at 248. 
however foreign they may be to our habits, traditions and modes of life, shall become at once citizens of the Umited States. ${ }^{12}$

Justice Brown, however, was quick to disclaim the implication that this decision represented a Dred Scott for the twentieth century. Citing the perhaps less-than-comforting example of the Chinese, he assured his readers that the Puerto Ricans were, "[e]ven if regarded as aliens, . . . entitled . . . to be protected in hfe, liberty, and property." 113

Racial concerns similarly dominated the congressional debate over statehood for Puerto Rico in 1912 and again in 1916. ${ }^{114}$ In 1917, the Jones Act declared all citizens of "Porto Rico" to be citizens of the United States. ${ }^{115}$ However, that "citizenship" had a peculiar msubstantiality. In his remarks on the bill, Senator Foraker commented:

We concluded ... that the inhabitants of that island must be either citizens or subjects or aliens. We did not want to treat our own as aliens, and we do not propose to have any subjects. Therefore, we adopted the term "citizens." In adopting the term "citizens" we did not understand, however, that we were giving to those people any rights that the American people do not want them to have. ${ }^{116}$

The Supreme Court supported this understanding of Puerto Rican citizenship as something less than full constitutional protection. For example, the Court held that the Sixth Amendment guarantee of a speedy trial does not apply to Puerto Rico; ${ }^{117}$ that the Fifth Amendment right to presentment or indictment by a grand jury does not apply to unincorporated territories; ${ }^{118}$ and that the Sixth Amendment right to confront the witnesses against one in a criminal trial does not apply to residents of the Philippines. ${ }^{119}$

112. Id. at 279-80 (emphasis added). As Brown opined further:

A false step at this time might be fatal to the development of what Chief Justice Marshall called the American empire. . . . If ... possessions are inhabited by alien races, differing from us in religion, customs, laws, methods of taxation, and modes of thought, the administration of government and justice, according to Anglo-Saxon principles, may for a time be impossible; and the question at once arises whether large concessions ought not to be made for a time, that ultimately our own theories may be carried out, and the blessings of a free government under the Constitution extended to them. We decline to hold that there is anything iu the Constitution to forbid such action.

$I d$. at 286-87. In contrast to this model of immediate incorporation, Justice Brown quoted from Johnson v. McIntosh, one of the founding cases of federal Indian law, to the effect that a conquered people is generally assimilated into the conqueror's nation. See Downes, 182 U.S. at 281.

113. Downes, 182 U.S. at 283 (citing Fong Yue Ting v. United States, 149 U.S. 698 (1893); Yick Wo v. Hopkins, 118 U.S. 356 (1886)).

114. See Rubin Francis WeSton, Racism in U.S. Imperialism 194-201, 204 (1972) (detailing these congressional debates, which focused on the Puerto Ricans' racial capacity for self-government).

115. See Jones Act, 39 Stat. 951 (1917) (codified at 2 U.S.C. $\$ 46,48$ U.S.C. $\$ \$ 731,733 a, 734$, 737-741a, 742, 745, 747-49, 751, 752, 863-65, 868, 870-72, 874, 891-93.)

116. 33 CONG. REC. 2473-74 (1900) (statement of Senator Foraker); see CABRANEs, supra note 106 , at 37.

117. See Balzac v. Porto Rico, 258 U.S. 298 (1922).

118. See Ocampo v. United States, 234 U.S. 91, 98 (1914).

119. See Dowdell v. United States, 221 U.S. 325, 331-32 (1911). 
In the end, and despite bitter dissents by Justices Fuller and Harlan, ${ }^{120}$ the Court's rulings in the Insular Cases created a new distinction between "incorporated" territories, to which the Constitution fully applies, and "unincorporated" territories. In these latter territories, inhabitants are not fully protected by the Constitution, but only possess "fundamental" constitutional rights. ${ }^{121}$ Not surprisingly, Congress bestowed the status of "unincorporated territory" only on the predominantly nonwhite holdings of the Umited States. ${ }^{122}$

A final outgrowth of the United States's adventures in Manifest Destiny overseas and Congress's now plenary power over the results was the emergence of several populations, all racially "nonwhite," with the anomalous political status of "noncitizen nationals." By 1934, legal scholar Dudley McGovney had identified several groups of people falling into this category. ${ }^{123} \mathrm{McGovney}$ further noted that congressional power to limit full

120. For example, in Hawaii v. Mankichi, 190 U.S. 197 (1903), Justice Harlan expounded at length on the corrupting effects of this imperialist policy on American constitutional democracy:

It would mean that the will of Congress, not the Constitution, is the supreme law of the land for certain peoples and territories under our jurisdietion. It would mean that the United States may acquire territory by cession, conquest or treaty, and that Congrcss may exercise sovereign dominion over it, outside of and in violation of the Constitution, and under regulations that could not be applied to the organized territories of the United States and their inhabitants. ... It would mean that, if the prineiples now announced should become firmly established, the time may not be far distant when, under the exactions of trade and commerce, and to gratify an ambition to become the dominant political power in all the earth, the United States will acquire territories in every direction, which are inhabited by human beings, over which territories, to be called "dependencies" or "outlying possessions," we will exereise absolute dominion, and whose inhabitants will be regarded as "subjects" or "dependent peoples," to be controlled as Congress may see fit, not as the Constitution requires nor as the people governed may wish. Thus will be engrafted upon our republiean institutions, controlled by the supreme law of a written Constitution, a colonial system entirely forcign to the genius of our government and abhorrent to the prineiples that underlie and pervade the Constitution. It will then come about that we will have two governments over the peoples subject to the jurisdiction of the United States-one, existing under a written Constitution, creating a government with authority to exercise only powers expressly granted and such as are necessary and appropriate to earry into effect those so granted; the other, existing outside of the written Constitution, in virtue of an unwritten law, to be declared from time to time by Congress, which is itself only a creature of that instrument.

Id. at 239-40 (Harlan, J., dissenting) (emphasis added).

121. See Dorr v. United States, 195 U.S. 138, 148 (1904).

122. An interesting question is why Alaska and Hawaii, both with significant nonwhite populations and both under consideration at roughly the same time, were not classified as unincorporated territories. The terms under which Hawaii joined the Union were extremely protective of the inhabitants' political and personal rights. See RINGER, supra note 11, at 954. Similarly, in Rassmussen v. United States, 197 U.S. 516, 525 (1905), the Court held that Congress had fully incorporated the territory of Alaska, eausing the Constitution to apply in its entirety. Perhaps the firm political hold of whites over Hawaii following the illegal overthrow of the Hawaiian government, and the extremely low population density of Alaska alleviated any anxieties Congress might otherwise have had about dangerous racial amalgamation. In Balzac v. Porto Rico, 258 U.S. 298, 309 (1922), for example, the Court distinguished Rassmussen by citing Alaska's relative lack of inhabitants and its location on the American continent.

123. They included: (1) more than $13,000,000$ persons designated "citizen of the Philippine Islands"; (2) a "possible handful of Puerto Ricans" who were said to have formally declined to become citizens of the United States when the Jones Act became law on March 2, 
citizenship to those racially fit for self-government apparently overrode the dictates of the Fourteenth Amendment. If the Fourteenth Amendment applied, then the children born in the Philippines and Puerto Rico since the cession of those islands to the United States would be American citizens, as persons born in the United States and subject to the jurisdiction thereof. But McGovney concluded that the law was in fact otherwise: "Consistently with precedents in our law, children born in the United States of parents who are non-citizen nationals are likewise noncitizen nationals, notwithstanding the Fourteenth Amendment."124 Thus, McGovney concluded:

If it is admitted, as I think it should be, that the treaty power of the United States can annex people without conferring citizenship on them, Congress may say, as I think in effect it has said, that the descendants of these non-citizen nationals shall to the end of time follow the status of their forebears. ${ }^{125}$

The law of "noncitizen nationals" hence directly contradicted Fourteenth Amendment norms of racial equality. Indeed, in this tributary of race law it was as if the Civil War had never occurred and Dred Scott was still good law. In that case, Justice Taney had held that descendants of Africans were forever to be outside the bounds of the American body politic, whether slave or free. For noncitizen nationals exactly the same was true; their racial unfitness would keep them and their children forever outside the American nation. ${ }^{126}$

\section{Equality in an Age of Difference: Nonwhite Citizens and the End of Emancipation}

The Radical Republicans' vision of a strong national government contravened strongly held views of the proper relations federalism required. In the years immediately following Reconstruction, the Suprenie Court effectively dismantled the machinery of legal equality in the name of

1917; (3) "[d]oubtfully, the Eskimos in Alaska in 1867 and their descendants wherever born"; (4) "inhabitants of Guam who acqnired American nationality in 1899 and their descendants wherever born"; (5) "[t]he Samoan Islanders who acquired [United States] nationality upon annexation and their descendants wherever born"; (6) "former citizens of the Republic of Panama who became American[s] ... upon the cession of the [Panama] Canal Zone, and their descendants wherever born"; and (7) if the citizenship provision of the Fourteenth Amendment were held not to apply to Guam, Puerto Rico, American Samoa, or the Canal Zone, "the children born there under American sovereignty to alien parents," who would "be aliens unless Congress legislate[d] to make them either citizen[s] or non-citizen nationals." Dudley O. McGovney, Our Non-Citizen Nationals, Who Are They? 22 Calif. L. Rev. 593, 631-32 (1934); see also Frederic R. Coudert, Jr., Our New Peoples: Citizens, Subjects, Nationals or Aliens, 3 Colum. L. REv. 13 (1903).

124. McGovney, supra note 123 , at 613 .

125. Id. at 613-14.

126. This reasoning is an example of what Neil Gotanda calls "status race": one's political and legal rights flow explicitly from one's place in a racial hierarchy. See Neil Gotanda, A Critique of "Our Constitution Is Color-Blind," 44 STAN. L. REv. 1, 4 (1991). 
federalism and states' rights. Though nonwhite citizens formally were entitled to legal equality in a way that nonwhite noncitizens were not, the practical reality was an end to black hopes for emancipation.

One of the first blows to the Reconstruction legal framework was struck early on. In 1873, the Supreme Court decided the Slaughter-House Cases. ${ }^{127}$ The facts did not involve race at all, ${ }^{128}$ yet the Court's decision effectively knocked out what might have been an important element of the constitutional structure of black freedom.

The constitutional heart of the case involved the meaning of section one of the Fourteenth Amendment, which forbade the states to infringe upon the "privileges or immunities" of national citizenship. Although historical evidence suggests that the drafters of the amendment had meant by "privileges or immunities" basic natural and civil rights, ${ }^{129}$ the Court held otherwise. The majority instead reasoned that these privileges and immunities must be distinct from the privileges and immunities of state citizenship. If the privileges and immunities of state citizenship included the natural, civil, and political rights of the individual, then the privileges and immunities of national citizenship must be only those beyond the reach of state governments: an odd collection of rights such as the right to travel to the national capital, the right to sue in federal courts, and the right to navigate the high seas. The Court admitted that this reading was somewhat strained.

But when, as in the case before us, these consequences are so serious, so far-reaching and pervading, so great a departure from the structure and spirit of our institutions; when the effect is to fetter and degrade the State governments by subjecting them to the control of Congress, in the exercise of powers heretofore universally conceded to them of the most ordinary and fundamental character; when in fact it radically changes the whole theory of the relations of the State and Federal governments to each other and of both these governments to the people; the argument has a force that is irresistible, in the absence of language which expresses such a purpose too clearly to admit of doubt. ${ }^{130}$

127. 83 U.S. (16 Wall.) 36 (1872).

128. The case involved a Louisiana statute giving a corporation a monopoly over the slaughtering of animals. The corporation argued that the law was an appropriate exercise of the state's police power; competing slaughter houses argued that the law violated the Thirteenth Amendment and the privileges or immunities clause of the Fourteenth Amendment by withholding from them the privilege of cngaging in a lawful business.

129. See generally NeLSON, supra note 22; see also Michael Kent Curtis, Resurrecting the Privileges or Immunities Clause and Revising the Slaughter-House Cases Without Exhuming Lochner: Individual Rights and the Fourteenth Amendment, 38 B.C.L. Rev. 1 (1996).

130. Slaughter-House Cases, 83 U.S. at 78. In dissent, Justice Field expressed a different view of the Fourteenth Amendment: "A citizen of a State is now only a citizen of the United States residing in that State. The fundamental rights, privileges, and immunities which belong to him as a free man and a free citizen, now belong to him as a citizen of the United States, and are not dependent upon his 
With this decision, as one commentator put it, "[f]or all practical purposes the privileges and immunities clause passed into the realm of historical oddities."131 The decision in the Slaughter-House Cases proved fatal to other federal statutes using national power to protect individuals against violations of their civil rights. ${ }^{132}$ But the federalism attack on civil rights went still further.

In an ironic twist (from a twentieth-century perspective), the Court found some of the Reconstruction statutes beyond the power of Congress to pass because they purported to protect persons of all races, not just blacks. In United States $v$. Reese, ${ }^{133}$ for example, the Court held that Congress lacked the power to pass a statute under which an indictnent against election inspectors was brought for refusal to count the ballots. Congress had overreached itself by purporting, based on the Fifteenth Amendment, to protect the voting rights not only of African Americans but of whites as well. ${ }^{134}$

The final and decisive judicial blow to Reconstruction however, was the Court's 1883 decision in the Civil Rights Cases. ${ }^{135}$ In these consolidated cases, the Court considered the constitutionality of sections one and two of the Civil Rights Act of $1875,{ }^{136}$ which provided protection against racial

citizenship of any State." Id. at 95 . This reading seems to be closer to what historians have identified as the amendment's legislative intent. See, e.g., JACOBUS TEN BROEK, EQUAL UNDER LAW 110 (1965); Nelson, supra note 22, at 164 ("Only the dissenting opinion of Justice Field read the historical background of the Fourteenth Amendment with any degree of accuracy.").

131. Gressman, supra note 43, at 1338. Not until 1997 was the Privileges or Immunities Clause resurreeted. See Saenz v. Roe, 526 U.S. 489 (1999); Laurence H. Tribe, Saenz Sans Prophecy: Does the Privileges or Immunities Revival Portend the Future-or Reveal the Structure of the Present?, 113 HARV. L. REV. 110 (1999).

132. See, e.g., United States v. Cruikshank, 92 U.S. 542 (1875). The case involved an indictment brought against more than one hundred people in the state of Louisiana under the 1870 Enforcement Act. The defendants were charged with conspiracy to prevent black people from exercising a variety of legal rights. Applying the reasoning of the Slaughter-House Cases, the Court held that the indictment was defective because the rights alleged to have been violated-the right to peaceably assemble, the right to bear arms, the right to life and liberty-were not nationally created or protected rights, but lay solely under the jurisdiction of the states to protect.

133. 92 U.S. 214 (1875).

134. See id. at 221. Using similar logic, the Court invalidated the conspiracy section of the Ku Klux Klan Act of 1871 in United States v. Harris, 106 U.S. 629 (1883). In that case, federal officials brought criminal charges against several local law enforcement officials in Tennessee for beating four African American men suspected of a crime and conspiring to permit their lynching. Again, it was the colorblind nature of the statute at issue that doomed it. Opined the Court:

A law under which two or more free white private citizens could be punished for conspiring or going in disguise for the purpose of depriving another free white citizen of a right accorded by the law of the state to all classes of persons-as, for instance, the right to make a contract, bring a suit, or give evidence-clearly cannot be authorized by the amendment which simply prohibits slavery and involuntary servitude.

Id. at 641 .

135. 109 U.S. $3(1883)$.

136. 18 Stat. $335(1875)$. 
discrimination in a variety of public accommodations. ${ }^{137}$ The Court concluded, in accordance with its prior cases, that Congress lacked the power to pass the Act under either the Thirteenth or Fourteenth amendments. Under the Fourteenth Amendment, the Court reasoned, Congress held only the power to adopt "corrective" legislation that nullified the effects of unconstitutional state legislation, and nothing more. ${ }^{138}$ Thus, the federal government could only provide remedies, not create new rights; and it could only provide relief against state action, not private action.

In its Thirteenth Amendment discussion, the Court conceded that Congress had the power to regulate not only state action under the Thirteenth Amendment, but the actions of private individuals as well. However, such legislation could only concern itself with "the badges and incidents of slavery."

The long existence of African slavery in this country gave us very distinct notions of what it was, and what were its necessary incidents. Compulsory service of the slave for the benefit of the master, restraint of his moveinents except by the master's will, disability to hold property, to make contracts, to have a standing in court, to be a witness agaimst a white person, and such like burdens and incapacities, were the inseparable incidents of the institution. ${ }^{139}$

But these practices had nothing to do with the "denial by the owner of an inn, a public conveyance, or a theatre, of its accommodations and privileges to an individual, even though the denial be founded on the race or color of that individual." 140 The Court concluded:

It would be running the slavery argument into the ground to make it apply to every act of discrimination which a person may see fit to make as to the guests he will entertain, or as to the people he will take into his coach or cab or car, or admit to his concert or theater, or deal with in other matters of intercourse or business. ${ }^{141}$

137. The facts of the case provide a glimpse into the world of late-nineteenth-century middle- and upper-class African Americans, who were bitterly resented by whites for "putting on airs." Two of the cases were indictments for denying to persons of color the accommodations and privileges of an inn or hotel, and two were for denying to individuals the privileges and accommodations of a theater, "the information against Ryan being for refusing a colored person a seat in the dress circle of Maguire's theater in San Francisco; and the indictment against Singleton being for denying to another person, whose color is not stated, the full enjoyment of the accommodations of the theater known as the Grand Opera House in New York." See Civil Rights Cases, 109 U.S. at 4; FonER, supra note 12, at 369 (describing the affront to well-off African Americans of racial discrimination in public accommodations).

138. See 109 U.S. at 11.

139. Id. at 22 . Note that by describing as badges and incidents of slavery only practices that required the partieipation of the state through the law, the Court limited the potential of its earlier suggestion that the Thirteenth Amendment had "establish[ed] and decree[d] universal civil and political freedom throughout the United States." Id. at 20.

140. Id. at 21 .

141. Id. at 24-25. Justice Harlan, writing in dissent, strongly disagreed with this argument separating race discrimination from slavery. 
The decision in the Civil Rights Cases thus separated "slavery" from "race discrimination" and interpreted "slavery" narrowly, reducing the Thirteenth Amendment to a rarely used provision. ${ }^{142}$ With respect to the Fourteenth Amendment, the opinion pushed the right to enjoy public accommodations on an equal basis into the category of "social rights," 143 which by all accounts were beyond the purview of constitutional equality. The Court had curtailed the power to protect American citizens against racial domination in the name of federalism.

In his dissent, Justice Harlan called attention to the fact that Congress had in the past exercised power now being described as belonging solely to the states-the most obvious example being the Fugitive Slave Actwithout constitutional challenge. ${ }^{144}$ Nevertheless, the notion that our

\begin{abstract}
I do hold that since slavery, as the court has repeatedly declared, was the moving or principal cause of the adoption of [the Thirteenth] amendment, and since that institution rested wholly upon the inferiority, as a race, of those held in bondage, their freedom necessarily involved immunity from, and protection against, all discrimination against them, because of their race, in respect of such civil rights as belong to freemen of other races. Congress, therefore, under its express power to enforce that amendment, by appropriate legislation, may enact laws to protect that people against the deprivation, on account of their race, of any civil rights enjoyed by other freemen in the same state; and such legislation may be of a direct and primary character, operating upon states, their officers and agents, and, also, upon, at least, such individuals and corporations as exercise public functions and wield power and authority under the State.
\end{abstract}

Id. at 36 (emphasis added). In Justice Harlan's view, moreover, the 1875 Act was constitutional under the Fourteenth Amendment because individuals and corporations in the operation of public accommodations perform public or quasi-public functions. See id. at 43 .

142. For an argument that the Thirteenth Amendment "was intended to lay the foundation for congressional attack against arbitrary class prejudice in all its chameleon forms," see G. Sidney Buchanan, The Quest for Freedom: A Legal History of the Thirteenth Amendment, 12 Hous. L. REv. 1, 23 (1974). With respect to the nature of "slavery," Laurence Tribe notes that after the Civil Rights Cases:

Subsequent thirteenth amendment decisions further restricted congressional power. In Hodges v. United States, the Supreme Court held that Congress ... could proscribe only those private acts which created a "state of entire subjection of one person to the will of another." "No mere personal assault or trespass or appropriation operates to reduce the individual to a condition of slavery." Moreover, in Corrigan v. Buckley and Hurd v. Hodge, the Court decided that the Thirteenth Amendment did not grant Congress power to prohibit agreements among whites to refuse to deal with blacks (e.g., racially restrictive covenants).

Laurence H. Tribe, I American Constitutional Law 925-26 (1999) (footnotes and citations omitted); see also Harold M. Hyman \& William M. Wiecek, Equal Justice Under LAW: ConstituTIONAL DEVELOPMENT I 835-1875, at 501-02 (1982).

143. For a fuller discussion of this point, see supra text acccompanying note 35 .

144. In Harlan's opinion, the majority's reading of the Reconstruction Amendments

would lead to this anomalous result: that whereas, prior to the amendments, congress, with the sanction of this court, passed the most stringent laws-operating directly and primarily upon states, and their officers and agents, as well as upon individuals-in vindication of slavery and the right of the master, it may not now, by legislation of a like primary and direct character, guard, protect, and secure the freedom established, and the most essential right of the citizenship granted, by the constitutional amendments.

Civil Rights Cases, 109 U.S. 3, 53 (1883) (Harlan, J., dissenting). 
national government is one of limited powers won the day when the contrary principle was establishmg black freedom. ${ }^{145}$

\section{a. Turning Domination into Difference}

Legislation is powerless to eradicate racial instincts or to abolish distinctions based upon physical differences, and the attempt to do so can only result in accentuating the difficulties of the present situation.

— Plessy v. Ferguson, 163 U.S. 537, 551 (1896)

One way of reconciling the post-Civil War regime of racial equality with the white race's continued hopes and expectations of dominance was to invalidate much of the new law of equality. Another way was to understand equality itself as consistent with inherent racial difference. Judicial opinions in the early twentieth century frequently and strenuously made the point that racial distinctions in the law did not reflect notions of superiority and inferiority, but only of "difference." So long as a statute on its face did not create relations of racial domination, but only recognized relevant differences, it did not offend the Constitution.

One element of the Court's early approach to equality was to confine itself strictly to the four corners of the rule under challenge. Plessy itself provides an example. As the majority explained in its now-famous dictum:

We consider the underlying fallacy of the plaintiff's argument to consist in the assumption that the enforced separation of the two races stamps the colored race with a badge of inferiority. If this be so, it is not by reason of anything found in the act, but solely because the colored race chooses to put that construction upon it. ${ }^{146}$ The Court's focus on the language of the statute alone, rather than its social operation, facilitated racial regulation.

Plessy's "formal equality" approach, under which the Court confined itself to whether the statutory language explicitly subordinated the rights of one race to another or was "colorblind," permitted the Court to uphold, without a twinge of conscience, legislative schemes obviously rigged for the purpose of denying African Americans their constitutional rights. Thus, in Williams $v$. Mississippi, ${ }^{147}$ decided in 1898 , the Court upheld against a

145. For a challenge to this view, arguing that the Court "reached surprisingly liberal conclusions about congressional power under the postwar Amendments, given the dominant ideas of federalism which provided the context in which they operated," see Miehael Les Benedict, Preserving Federalism: Reconstruction and the Waite Court, 1978 SuP. CT. REv. 39, 41 (1979).

146. Plessy v. Ferguson, 163 U.S. 537, 551 (1896). The Court had previously observed, "A statute which implies merely a legal distinction between the white and colored races-a distinction which is founded in the color of the two races, and which must always exist so long as white men are distinguished from the other race by color-has no tendency to destroy the legal equality of the two races, or re-ëstablish a state of involuntary servitude." Id. at 543 .

147. 170 U.S. 213 (1898). 
Fifteenth Amendment challenge Mississippi's enactment of new voter qualifications that excluded black citizens from political participation. Under Mississippi's new system, applicants to vote both had to pay a poll tax and to demonstrate to an administrative officer's satisfaction that that they could read any section of the Constitution or be able to understand or give a reasonable interpretation of it. The officer's discretion, of course, was absolute. Setting forth the rationale for these new voter qualifications, the Supreme Court of Mississippi explained of the black race:

By reason of its previous condition of servitude and dependencies, this race had acquired or accentuated certain peculiarities of habit, of temperament, and of character, which clearly distinguished it as a race from the whites; a patient, docile people; but careless, landless, migratory within narrow limits, without forethought, and its criminal members given to furtive offences, rather than the robust crimes of the whites. Restrained by the federal constitution from discriminating against the negro race, the convention discriminates against its characteristics, and the offences to which its criminal members are prone..$^{148}$

Searching this description for racial discrimination, the United States Supreme Court concluded that "nothing tangible can be deduced from this.... [T] he operation of the constitution and laws is not limited by their language or effects to one race. They reach weak and vicious white men as well." 149

As well as fostering "colorblind" statutes that in their social operation promoted white supremacy, Plessy fostered the proliferation of state racial regulation in the name of "difference." For example, Gilbert Thomas Stephenson's 1910 treatise, Race Distinctions in American Law, studied the effect of Plessy. According to Stephenson, by 1910, "[t]here [was] scarcely a State or Territory in the Union where legislative or judicial records [did] not reveal the actual existence of at least some race distinctions." A key distinction in Stephenson's analysis was between racial "distinctions" and "discriminations." "A race distinction connotes a difference and nothing more. A discrimination iniplies partiality and favoritism."150 As long as statutes contained distinctions and not unconstitutional discriminations, racial regulations were legal, even wise. The reality of race meant that the state could and should justly keep the races apart, lest natural racial hostilities destabilize society and hinder racial development. Judicial opinions in the first half of the twentieth century repeatedly stated that the law could eradicate neither "natural" racial differences nor interracial hostility and competition, which was similarly

148. Id. at 222 .

149. Id.

150. Gilbert Thomas Stephenson, Race Distinctions in american Law 348, 4 (Mnemosyne 1969) (1910). 
"natural." 151 As Stephenson wrote, "[R]ace distinctions are not based fundamentally upon the feeling by one race of superiority to the other, but are rather the outgrowth of race consciousness."152

The "different but equal" rhetoric rejected the openly white supremacist visions offered around the same time by popular writers such as Thomas Dixon, ${ }^{153}$ by some of the early writings of Theodore Roosevelt, ${ }^{154}$ and by racial Darwinists who saw the white race as the pinnacle of civilization. ${ }^{155}$ Moreover, this concept of difference rejected the preReconstruction assumption (still applicable to the law governing nonwhite citizens) that legal rights and responsibilities could turn on one's racial status. ${ }^{156}$ Courts were quick to emphasize the point that racial differences did not necessarily mean relations of superiority and inferiority. For example, in 1922, when the Supreme Court held that a Japanese immigrant could not become a naturalized citizen because he was nonwhite, the opinion ended with a disclaimer: "Of course there is not implied-either in the legislation or in our interpretation of it-any suggestion of individual unworthiness or racial inferiority. These considerations are in no manner involved." 157 The following year, after finding a subcontinental Indian man to be "Caucasian" but still not white under the same statute, the Court similarly reassured its audience: "It is very far from our thought to suggest the slightest question of racial superiority or inferiority. What we suggest is merely racial difference, and it is of such character and extent

151. See, e.g., Plessy, 163 U.S. at 551("Legislation is powerless to eradicate racial instincts or to abolish distinctions based upon physical differences, and the attempt to do so can only result in accentuating the difficulties of the present situation.").

152. STEPHENSON, supra note 150 , at 353 .

153. See supra note 56.

154. See Roosevelt, supra note 61 (applauding American intervention in Cuba, Puerto Rico, Guam, and the Philippines in the name of the white man's duty to bring civilization to less-developed peoples).

155. See infra text accompanying note 192 .

156. An example of the earlier "status" reasoning appears in Roberts v. City of Boston, 59 Mass (5 Cush.) 198 (1849). In that case, Chief Justice Lemuel Shaw reconciled the notion of equality with the practice of inequality with a frank admission that the law itself could and should treat people differently on the basis of their station in life:

The great principle, advanced by the learned and eloquent advocate of the plaintiff, is, that by the constitution and laws of Massachusetts, all persons without distinction of age or sex, birth or color, origin or condition, are equal before the law.... But, when this great principle comes to be applied to the actual and various conditions of persons in society, it will not warrant the assertion, that men and women are legally clothed with the same civil and political powers, and that children and adults are legally to have the same functions and be subject to the same treatment; but only that the rights of all, as they are settled and regulated by law, are equally entitled to the paternal consideration and protection of the law, for their maintenance and security. What those rights are, to which individuals, in the infinite variety of circumstances by which they are surrounded in society, are entitled, must depend on laws adapted to their respective relations and conditions. Id. at 206.

157. Ozawa v. United States, 260 U.S. 178, 198 (1922). 
that the great body of our people instinctively recognize it and reject the thought of assimilation." 158

The new "pluralist" racism was racism with a friendly face: it was not domination but racial family feeling and cultural difference that the law reflected. Yet the line between Stephenson's "distinctions" and "discriminations" was not as clear as one might think. Endeavoring to locate the ultimate cause of race distinctions, Stephenson fell back on the realm of the natural. "No comparison of laws can formulate an answer to that question; but the personal observation of the writer leads to the belief that race distinctions are not based fundamentally upon the feehing by one race of superiority to the other, but are rather the outgrowth of race consciousness." 159 This consciousness, in turn, stems from the existence of racial groups themselves, which compete with one another for status and sometimes have different "ideals."

If Negroes were in every way equally advanced with white people, race distinctions would probably be even more pronounced than now; because, in addition to physical differentiation, there would be the rivalry of equally matched races. Thus, the widespread prejudice entertained by Gentiles toward Jews, resulting in actual, if not legal, distinctions, is due, not to any notion that Jews are intellectually or morally inferior to any people, but to a race consciousness which each possesses. The exclusion of the Japanese was due, not so much to an intellectual or moral inferiority of that race to the white race, as to a difference in their racial ideals. So long as two races living side by side have each an amour propre, the more numerous may be expected to prescribe distinctions to which the less nunerous must submit; that is, until the spirit of universal brotherhood is a more compelling force than it is at present. ${ }^{160}$

But if each race is motivated by pride and wishes to retain its distinctiveness, why is it the "more numerous" race that "prescribes" distinctions to which the less numerous race must submit? Either both races ought to welcome the distinctions and develop them by mutual agreement, or the distinctions really have something akin to "discrimination" inherent to them after all. This is to suggest that the new law of equality did not really change domination into mere difference at all. Rather, as literary critic Walter Benn Michaels argues, "the commitment to difference itself represents a theoretical intensification rather than diminution of racisn1." 161

158. United States v. Thind, 261 U.S. 204, 215 (1923).

159. STEPHENSON, supra note 150 , at 353.

160. Id. at 353-54.

161. Walter Benn Michaels, Our America: Nativism, Modernism, and Pluralism 65 (1995). For an astute discussion of Michaels' concept of "pluralist racism" in the context of immigration, see Robert S. Chang, Disoriented: Asian Americans, Law, and the NationSTATE 27-42 (1999). Other commentators have similarly described this concept-formal commitment 
This intensification was manifested in the emergence of de jure segregation in the South, under which nearly every aspect of daily life could be racialized. Here the reasoning of Plessy called for broad authority on the part of the state and local governments to weave racial difference into the law. Thus, in Plessy itself, "[T]he case reduce[d] itself to the question whether the statute of Louisiana is a reasonable regulation, and with respect to this there must necessarily be a large discretion on the part of the legislature." ${ }^{162}$ Moreover, "[i]n determining the question of reasonableness [the Louisiana legislature] is at liberty to act with reference to the established usages, customs, and traditions of the people."163 That these usages, customs, and traditions were frequently being created, not merely reflected, by the law typically went unnoticed.

\section{b. Nonstate Action as Race Law}

The assumption that the races were inherently different and that the courts should defer to local "customs" of racial separation facilitated the construction and enforcement of an "unwritten law": a dense network of racial prohibitions enforced by public and private violence, yet operating beyond the law of the state. The most horrifying example, of course, is the practice of lynching. In 1904, a Vicksburg, Mississippi newspaper reported on the murder of Luther Holbert, a black sharecropper, and his wife by a mob of more than one thousand whites:

to the truth of racial difference while simultaneously rejecting intimations of racial hierarchy-as a form of racism. For example, philosopher Anthony Appiah defincs "racialism" as "the view ... that there are heritable characteristics, possessed by members of our spccies, which allow us to divide them into a small set of races, in such a way that all the members of these races share certain traits and tendencies with each other that they do not share with members of any other race." KWAME ANTHONY ApPiah, IN MY Father's House: Africa IN The PhILosophy of CUlture 13 (1992). "[E]xtrinsic racists make moral distinctions between members of different races because they believe that the racial essence entails certain morally relevant qualities," while "intrinsic racist[s] hold[] that the bare fact of being of the same race is a reason for preferring one person to another." Id. at 13-14 (emphasis added). "Pluralist racism" is a form of intrinsic racism, since it assumes that America must be kept white simply because it is "ours" and "we" are white. Similarly, philosopher Etienne Balibar, borrowing from P.A. Taguieff, describes as "differentialist racism" a thinking "whose dominant theme is not biological heredity but the insurmountability of cultural differences, a racism which, at first sight, does not postulate the superiority of certain groups or peoples in relation to others but 'only' the harmfulness of abolishing frontiers, the incompatibility of life-styles and traditions." Etienne Balibar, Is There a "NeoRacism'? in Etienne Balibar \& Immanuel Wallerstein, Race, Nation, Class: Ambiguous IDENTITIES 17, 21 (Chris Turner trans., 1991).

162. Plessy v. Ferguson, 163 U.S. 537, 550 (1896).

163. Id. Cass Sunstein points out that the Court's approach in Plessy drew on:

[A] time-honored but highly controversial understanding of law, especially of the judge-made common law. On this understanding, the common law is not an imposition of the judgcs' will, but instead a reflection of social customs and practices. This view was especially prominent in America in the late nineteenth century. It served to deepen the claim that the common law of tort, contract, and property could be secn as a kind of natural state.

Cass R. Sunstein, The Partial Constitution 43 (1993). 
[T] pyres were being prepared, they were being forced to hold out their hands while one finger at a time was chopped off. The fingers were distributed as souvenirs. The ears ... were cut off. Holbert was beaten severely, his skull fractured and one of his eyes, knocked out with a stick, hung by a shred from the socket. Some of the mob used a large corkscrew to bore into the flesh of the man and woman. It was applied to their arms, legs and body, then pulled out, the spirals tearing out big pieces of ... flesh every time it was withdrawn. ${ }^{164}$

Racial violence in the Progressive Era was nothing new. The distinctive feature of white violence against nonwhites in the early twentieth century, however, was the conjunction of horrific violence, often involving widespread public participation, and a new body of law requiring racial equality. The ironic term "Judge Lynch" captures the sense that lynching was both against the law and constituted the most extreme enforcement of the law.

The Supreme Court's decision in Plessy had drawn a line between the sphere of the legal and the sphere of the social. In the social sphereincluding public accommodations, marriage, and education-government regulation by race would be upheld as long as the regulations were "reasonable." 165 To decide what was reasonable, in turn, the courts were to look to "custom," or private orderings. These private orderings, in fact, were often less the product of tradition than of violence and terror. Yet as long as the state was not officially involved in perpetrating this racial terror, the Constitution was not violated. The distinction between "private" and "public" orderings, then, permitted a reconciliation between the legal

164. RaLPH GinzBURG, 100 YEARS OF LYNChings 63 (1969). See generally RANDALl KENNEDY, RACE, CRIME, AND THE LAW 41-49 (1997) (describing lynching as used to realize the goal of white supremacy, and the role of lynching in black politics); Barbara Holden-Smith, Lynching, Federalism, and the Intersection of Race and Gender in the Progressive Era, 8 YALE J.L. \& FEMINISM 31 (1996) (describing the failure of Congress to enact anti-lynching legislation).

165. Indeed, as long as the racial regulations fell well within the social sphere and hence within the police power, principles of federalism discouraged any real review. See, e.g., Gong Lum v. Rice, 275 U.S. 78 (1927). The Court's opinion, permitting a Mississippi school district to keep Martha Lum out of the local "white" school and relegate her to the "colored" school, is typical:

Under the circumstances disclosed, we cannot say that this action of the state court was, within the meaning of the Fourteenth Amendment, a denial by the state to the plaintiffs and to those associated with them of the equal protection of the laws, or of any privileges belonging to them as citizens of the United States. We may add that, while all admit that the benefits and burdens of public taxation must be shared by citizens without discrimination against any class on account of their race, the education of the people in schools maintained by state taxation is a matter belonging to the respective states, and any interference on the part of federal authority with the management of such schools cannot be justified, except in the case of a clear and unmistakable disregard of rights secured by the supreme law of the land.

Id. at 85 (quoting Cumming v. Richmond County Bd. of Educ., 175 U.S. 528, 545 (1899)). 
norms mandating racial equality and social norms mandating white supremacy.

The blurriness of the line between public and private meant that "private" acts of terror could in practice have the force of law. Lynchings provide an example. Though technically criminal, and often deplored in the press, lynchings were usually publicly justified by reference to the crime allegedly committed by the victim-a crime that had understandably (if regrettably) inflamed a mob fearful that the legal process would not do its duty, or would not do its duty quickly enough. Thus, even those who condemned lynchings strained to sympathize with the lynchers and to deplore the crimes supposedly committed by the lynch mobs' victims-in the South, usually the rape by a black man of a white woman. Lynchings in this view represented not lawlessness, but regrettable overenthusiasm in the protection of legal norms. They could even be seen as the fulfillment, rather than the violation, of the law. As a commentator from the previous century had noted:

The Lynch-law, is not, properly speaking, an opposition to the established laws of the country, or, is at least, not contemplated as such by its adherents; but rather as a supplement to theni,-a species of common law, which is as old as the country, and which, whatever may be the notion of "the learned in the law," has nevertheless been productive of some of the happiest results. ${ }^{166}$

Lynchings had a quasi-legal status in part because they could be justified as upholding legal norms. They also had a quasi-legal status because of the complicity of legal actors. As a practical matter, many lynchings could not have occurred, or could not have gone unpunished, without the ineffectiveness, acquiescence, and even cooperation of law-enforcement officials, prosecutors, and grand and petit juries. By the 1930s, for example, most of the southern states had outlawed lynching, but their statutes were less than all inclusive, focusing only on the kidnapping of prisoners already in custody rather than the killings of persons not accused of a crime at all. Congress passed no federal legislation at all punishing lynching during the heyday of the lynch mob. It was often tacitly understood, moreover, that local law enforcement would turn a blind eye to lynch mobs, or even covertly facilitate the crinie. ${ }^{167}$ The weakness of the law on the books and the active or passive obstruction of justice by those charged

166. JAMES ElbeRt CUTLER, LyNCh-LAW: AN INVESTIGATION INTO THE HistoRy OF LyNCHING in the United States 113-14 (Negro Univ. Press 1969) (1905) (quoting F. J. Grund, The Americans in Their Moral, Social, and Polmtical Relations 323 (1837)).

167. See KENNEDY, supra note 164, at $88-90$ (discussing the pressure that lynchings put on court proceedings). 
with enforcing the law meant that, in effect, lynch mobs themselves represented the law. ${ }^{168}$

The use of private violence to terrorize nonwhite populations was not limited to lynchings. In the first few decades of the twentieth century, race riots-typically instigated by whites and directed toward African American or Chinese communities-were a frequent occurrence. Some, "Southernstyle" riots, were outgrowths of lynchings, usually originating in a claim of interracial rape; others, "Northern-style" riots, were sparked by perceived intrusions of people of color into white social perquisites, such as jobs or neighborhoods. ${ }^{169}$ Race riots, like lynchings, performed the function of protecting white symbolic and material interests. Pursuant to the "unwritten law," such riots expressed the white conviction that Chinese and African Americans were not entitled to equal status im the social realm. Soine riots aimed merely to keep nonwhite people "in their place"; others were aimed at racial cleansing. Philip Fradkin gives an early example, from California at the time of the Chinese Exclusion Act:

Whites from Truckee, Eureka, Turlock in the San Joaquin Valley, and Los Angeles, as well as many other communities throughout the state, turned to violence to rid their communities of the hated Celestials. In Humboldt County, the citizens waited for a pretext....

That pretext came at 6:05 P.M. on Friday, February 6, 1885, when two Chinese men exchanged shots. A Eureka city councilman walking to his downtown office was hit by a stray bullet and killed. Within minutes an unruly crowd was yelling for the mass execution of all Chinese and the burning of the Chinatown section of Eureka. A meeting, chaired by the inayor, was held within twenty minutes of the shooting. The crowd continued to call for the massacre of all Chinamen and the destruction of their property. Some recalled the precedent for such a massacre that had been established a quarter-century earlier on the island [when two hundred or so Indians, mainly old men, women, and children, were massacred by whites under the direction of a vigilante committee, a crime that was never prosecuted].

Cooler heads prevailed, and a citizens' committee was dispatched to tell the more than two hundred Chinese residents of

168. Barbara Holden-Smith calculates that "about eight-tenths of one percent of the lynchings in the United States since 1900 have been followed by convictions of the lynchers. Meanwhile, convictions for regular homicides during the same period ran at forty-four percent." Holden-Smith, supra note 164 , at 40.

169. Up until 1917 or so, race riots usually were purely one-sided affairs, described by some scholars as "pogroms"; later, these riots began to involve mutual violence. Grimshaw, cited by RINGER, supra note 11, at 283, argues that the Chicago race riot of 1919 marks a transition in black-white riots. In that riot and in subsequent ones, the trigger was no longer the protection of white "sacred values" but purely material interests. In that riot and in subsequent ones, moreover, the communities under siege fought back. 
Eureka, and perhaps an equal number in the unincorporated areas of the county, to pack up and be ready to depart within twenty-four hours. The next morning the streets of Chinatown were piled high with hastily assembled baggage. By noon the holds of two steamships ... were loaded with the possessions of the Chinese, some of whom had been in Eureka for almost as long as the thirtyfive years it had been in existence. The Chinese in the hinterlands were rounded up, but a few managed to escape the dragnet, only to be hunted down later.

A small Chinese boy, on his way to where he had been directed to go by the whites, was grabbed off the street and a noose was fitted around his neck. It led to a rope that was attached to a scaffold. A sign on the gallows read ANY CHINAMAN SEEN ON THE STREET AFTER THREE O'CLOCK WILL BE HUNG TO THIS GALLOWS. The police did nothing. The badly frightened boy was finally released on the pleadings of a clergyman.

Because of rough seas breaking on the bar at the entrance of the bay, the ships did not depart until Sunday. After a two-day voyage down the coast, the vessels arrived in San Francisco. The fearful passengers melted into that city's Chinatown. A suit seeking damages for those expelled from Eureka was filed in federal court, but it never went anywhere. Back in Eureka a mass meeting was held and resolutions - what came to be referred to as the "unwritten laws"-were passed barring the Chinese from the city. The "laws" were then extended to county territory and elsewhere on the north coast as other communities kicked out their Chinese residents.

The unwritten laws were on no official books, but they were etched into memories and passed on from generation to generation. In 1906 a salmon canning company imported twenty-three Chinese and four Japanese laborers. Upon their arrival, the Humboldt Times declared in a blazing headline THE CHINESE MUST GO! They went; there is a photograph of them standing on a barge being pushed down the bay by a small tug, with Eureka's stately yacht club in the background. ${ }^{170}$

In such cases, local law enforcement was obviously not likely to punish the perpetrators. Yet, federal law provided no recourse either, for the courts had found federal protection of civil rights unconstitutional. In Baldwin v. Franks, ${ }^{171}$ for example, the petitioner sought a writ of habeas corpus after being arrested on a federal warrant for conspiring with others to drive a number of Chinese residents out of the town of Nicolaus, in Sutter County, California. Like the Chinese residents of Eureka, Sing Lee and others were driven from their homes, unlawfully detained for several hours, and finally forced onto a steamboat barge and driven from the

170. Philip L. Fradkin, The Seven States of California: A Natural and Human History 183-84 (1995).

171. 120 U.S. 678 (1887). 
county. The Supreme Court took the case to decide, first, the constitutionality of a federal law providing for the punishment of anyone who "in any state or territory conspire[s] . . for the purpose of depriving, either directly or indirectly, any person or class of persons of the equal protection of the laws, or of equal privileges and immunities under the laws." ${ }^{172}$ Relying on United States v. Harris, ${ }^{173}$ the Court found the law unconstitutional.

The Court then turned to a section of the civil rights laws that had already passed constitutional muster, punishing conspiracies to "intimidate any citizen in the free exercise or enjoyment of any right or privilege secured to him by the constitution or laws of the United States." ${ }^{174}$ Here, the Court held that the Chinese were not citizens, but rather "mere persons, residents or inhabitants," not protected by the statute. ${ }^{175}$ Fimally, the Court ruled inapplicable a statute punishing those who conspire to "prevent, hinder, or delay the execution of any law of the United States."176 Though the Burlingame Treaty protected the personal rights of Chinese persons in the United States, the Court held that Baldwin's "force was exerted against the Chinese people, and not against the government in its efforts to protect them." ${ }^{177}$ Thus, the unwritten laws proved paramount to the written ones.

Private organizations explicitly dedicated to creating and enforcing the unwritten laws sprang up as well in the post-Reconstruction West and South. These organizations, such as the Ku Klux Klan, held as their agenda to protect white social identity, white women, and white political and economic dominance through terror. The quasi-anonymous acts of terrorism committed by such groups, when combined with public nonenforcement of the law at the state level and the lack of protection against "private" violence at the federal level, gave such groups a quasi-legal authority and, for nonwhites, made unchallengeable the "unwritten laws" of race relations. Yet these groups" "private" character shielded them from federal interference. ${ }^{178}$ The unwritten laws were so effective that by the early part of the twentieth century, with the help of white population influxes from the midwestern states, Los Angeles and other formerly multiracial cities could boast of their white character:

172. Id. at 683-84.

173. 106 U.S. 629 (1883).

174. 120 U.S. at 684 .

175. Id. at 691 .

176. Id. at 684 .

177. Id. at 694; see also Hodges v. United States, 203 U.S. 1 (1906) (holding that there was no federal remedy for black laborers in a lumber mill prevented from fulfilling their labor contracts by a conspiracy of three whites to use violence against them: no state action for Fourteenth Amendment purposes, and no protection against crimes or torts under the Thirteenth).

178. A related phenomenon was the use of clearly invalid laws to coerce plantation croppers, tenants, and workers into fulfilling their contracts under threat of criminal punishment. The Supreme Court held these "peonage" statutes unconstitutional in cases such as Bailey v. Alabama, 219 U.S. 219 (1911). Yet despite their invalidity, they were enforced well into the 1940s. See Pollack v. Williams, 322 U.S. 4, 15 (1944); Lindner, supra note 89, at 1348-49. 
The image of Los Angeles as the "White Spot of America," as the Times called it, peaked around 1930. Saturday Evening Post readers were assured that Los Angeles residents were "native Americans almost in total." The coastal city of El Segundo boasted it had "no negroes or Mexicans." Long Beach, which actually had a sizable Mexican population, claimed that 98 percent of its inhabitants "are of the Anglo-Saxon race." Joseph Lilly, a former New York City newspaperman, wrote in the North American Review that, despite a large Mexican population, Los Angeles was "peculiarly 'white' in the composition of its population." He added that the city is "an interesting experiment for the Anglo-Saxon in America." 179

The "whiteness" of these cities and others, as well as the whiteness of neighborhoods, public institutions, and public accommodations, was maintained not only by violent exclusion of nonwhites from the city limits, but also by extensive segregation of nonwhites within city limits into separate neighborhoods, separate schools, separate churches, and into menial or service occupations where they would be seen but not heard. This type of segregation would later be called de facto as opposed to de jure segregation, but it might better be termed segregation pursuant to "unwritten" rather than "written" law. It was extensive segregation of this sort that permitted Los Angelenos to think of themselves as living in a "white" city while in the presence of so many Mexicans.

Where geographic segregation could not be easily accomplished, as in the South, elaborate legalized segregation in public and private facilities, along with heavily ritualized social interaction, performed the function of marking out whiteness as a protected social status. In both de facto and de jure segregation, however, the linchpin-pun intended-was the rule against miscegenation. Where, as in the North and West, nonwhites were effectively bamished to geographically distant worlds, miscegenation was a less potent threat. In the geographically integrated South, however, the fear of miscegenation seemed to grip whites like a fever. The virulence of the taboo on interracial intimacy and the violence with which even imaginary violations were punished-bodies of black men dismembered, mutilated, burnt, left swinging from trees-spoke to whites' desperate need to protect white supremacy and white purity at all costs.

I have argued that the noninterference of state and federal authorities regarding white violence blurred the line between "private" and public action. A second slippage between the private and the public emerged from the use of the criminal law to enforce the unwritten laws of race. Statutes that gave the police broad discretion to prevent crime-such as statutes criminalizing vagrancy and disorderly conduct-could also be used to

179. FRADKIN, supra note 170, at 383. 
enforce American apartheid, as the Supreme Court would later recognize in Papachristou v. City of Jacksonville. ${ }^{180}$ Black and Mexican people in white neighborhoods might be arrested on suspicion of committing a crime. Conversely, crimes committed within communities of color typically received last priority and little or no energy, effectively enlisting the state in maintaining a condition of lawlessness in nonwhite neighborhoods. ${ }^{181}$ Again, the deference given to state and local governments by the federal government ensured the maintenance of this "home rule" by white law enforcement. Nonwhites could identify no legal wrongs, no violation of the rule of equality, as long as deference to custom, the police power, and police discretion in the realm of the "social" was part of the constitutional law.

Private violence-and police power in both its literal and technical senses-provided the framework within which nonwhite people exercised their rights in the Progressive Era. Even where the Supreme Court did intervene on behalf of nonwhites-as it sometimes did in this period, striking down racial restrictions on the transfer of property ${ }^{182}$ invalidating "grandfather clauses," 183 and striking down so-called peonage statutes ${ }^{184}$ the unwritten laws of racial subordination rather than the printed law of equality held sway over the actual lives of nonwhite people. Private racial covenants substituted for state regulation of real estate transfers. Grandfather clauses were supplanted by literacy tests that were formally raceneutral but unequally applied in practice. Prison chain gangs took over where peonage left off. ${ }^{185}$

For nonwhites in the new century, then, race law-enforced by "private" violence or literally by police power--determined where and with whom nonwhites could eat, work, worship, marry, play, live, and travel. Though the lines between public and private, federal and state, were meaningful in the courts to reconcile legal equality with social inequality, in American daily life there was little distinction. The law was everywhere, and written or unwritten, the author was "The Man."

180. 405 U.S. 156 (1972); see discussion infra. Criminal law, of course, could be used to punish violations of de jure segregation, as well. See, e.g., KENNEDY, supra note 164, at 88 ("During the age of segregation, authorities used the criminal law to impose a stigmatizing code of conduct upon Negroes, one that demanded exhibitions of servility and the open disavowal of any desire for equality.").

181. See KENNEDY, supra note 164 , at 69-74.

182. See Buchanan v. Warley, 245 U.S. 60 (1917).

183. See Guinn and Beal v. United States, 238 U.S. 347 (1915); Myers v. Anderson, 238 U.S. 368 (1915).

184. See United States v. Reynolds, 235 U.S. 133 (1914); Bailey v. Alabama, 219 U.S. 219 (1911). See generally Benno Schmidt, Principle and Prejudice: The Supreme Court and Race in the Progressive Era. Part 2: The Peonage Cases, 82 Colum. L. Rev. 646 (1982).

185. See David M. Oshinsky, Worse than Slavery: Parchman Farm and the Ordeal of JiM Crow Justice (1996). 


\section{Race Law and White Subjects in the Age of Difference: Maintaining the Quality of Whiteness}

As we have seen, the norms of racial equality introduced into American race law by the first Reconstruction did not eradicate the law's participation in racial subordination. Where nonwhite populations were not subject to the protections of equality, the law continued to participate in the creation of "whites" and "nonwhites," and continued to facilitate white acts of domination over nonwhites. Even where nonwhite persons were entitled to equal treatment, the courts extended deference to state and nonstate practices of racial categorization and racial subordination.

In the first few decades of the twentieth century, moreover, racialist philosophies and practices intensified, expanding to take whites themselves as their subject. In this Part, I discuss the extension of nativist racism to "white" immigrants and finally even to white "natives."

\section{Whiteness and Nationalism: Americanizing Non-Anglo-Saxons}

In 1915, a rural Southerner named George Simmons had an inspiration: he revived the Ku Klux Klan, naming it the Invisible Empire of the Knights of the Ku Klux Klan, and named himself its Imperial Wizard. ${ }^{186}$ According to historian John Higham, Simmons's

first acts as Imperial Wizard were to draw up the high-sounding ritual of the Kloran, create a galaxy of Kleagles, Kligrapps, Cyclops, Geniis, and Goblins, and summon his little band of followers to Stone Mountain, where they dedicated themselves before a flaming cross and a flag-draped altar to uphold Americanism, advance Protestant Christianity, and eternally maintain white supremacy. ${ }^{187}$

The new Invisible Empire differed from the original Klan in several ways. First, while the original Klan had been run by whites who saw themselves as rebels against the United States, the new Klan reflected a convergence of old-style Southern white supremacy with a new patriotic nationalism that focused on the greatness of the Anglo-Saxon race, a greatness illustrated by the resounding American success in the War of 1898 . Glorifying Anglo-Saxon traditions and extolling the Anglo-Saxon's destiny of conquest and triumphant rule turned out to be compatible with the veneration of the United States and its unique global destiny. "White supremacy was becoming ... the American Way." 188

Second, the new Invisible Empire expanded its sights beyond the old goal of keeping African Americans down. Although the new KKK's

186. See John Higham, Strangers in the Land: Patterns of American Nativism, i860I925, at 286-87 (2d ed. 1971).

187. Id. at 287-88.

188. Id. at 170 (attributing phrase to C. Vann Woodward). 
activities in this regard were exemplary-Klansmen paraded through southern towns on the eve of the 1920 election to terrorize black people out of voting, intimidated black workers and pressured white employers to fire or demote them, and forced black people out of a part of South Jacksonville that white people wanted for themselves alone, to name a few examples-by 1921 the KKK was in fact "specializing in attacking white people." 189 Klan leaders had joined in a burgeoning anti-Semitism with zest; supported restrictions on European immigration in the name of preserving white purity; and had generally turned the KKK into a free-ranging moral crusade dedicated to upholding, by terror and intimidation, Christianity and patriotism. ${ }^{190}$

In the early decades of the twentieth century, and particularly in years leading up to the Immigration Act of 1924, American race consciousness took on a nativist cast. World War I touched off a patriotic fervor from which emerged the term "100\% American" as a term of approbation. ${ }^{191}$ The new American race consciousness had also begun to distinguish among whites. As we have already noted, the influx of new immigrants such as Greeks, Poles, Hungarians, Armenians, and Russian Jews, and their concentration in inner-city slums touched off a concern with social conditions that in its benign form led to settlement houses and night programs to learn English and civics, and in its malign form led to diatribes against the racially unfit. Meanwhile, race scientists were working hard to apply the insights of Darwin to the human race. The new science of eugenics seemed to place the perfection of the white race within reach if only whites could be persuaded to adopt its principles as guides for private life and public policy.

The convergence of patriotic xenophobia with an intensified, newly "scientific" racialism was a philosophy that distinguished racially among whites. In 1916, Madison Grant had published a book, The Passing of the Great Race. ${ }^{192}$ Grant distinguished three European racial types: the Alpines, a race of "peasants"; the Mediterraneans, who were generally inferior but did possess some artistic and intellectual gifts; and the Nordics, who possessed political and military genius and were destined to rule the world if their great heritage remained untainted. Unfortunately, in Grant's view, the future of the United States-whose people had previously been of primarily Nordic stock-was being endangered by swarms of Alpines, Mediterraneans, and particularly Jews, for whom Grant harbored a special hatred. Grant contended that race mixing threatened the Nordic race

189. Id. at 290 .

190. See id. at 294 (discussing the Klan as a self-appointed instrument for moral conformity).

191. See id. at 204.

192. Madison Grant, The Passing of the Great Race; or, The Racial Basis of European HistoRy (1916). See also Higham, supra note 186, at 156-57 (describing Grant's argument). 
because of "reversion": the cross between a "higher," more civilized type and a "lower," more primitive type would yield the lower type. Moreover, the Nordics were in danger of committing "race suicide": reproducing in ever-smaller numbers while the lower races multiplied uncontrollably. ${ }^{193}$ Grant's book received only modest attention when it was initially published, but it enjoyed widespread popularity and influence in the early 1920s. Grant's vision of the significance of race within European populations, like the KKK, had gone mainstream.

Several kinds of legal initiatives emerged from this new expansion of race consciousness to whites. First, in the years following World War I, many state and local governments took steps to discriminate against aliens, and to make it easier to punish aliens and citizens suspected of ideological disloyalty, and to keep schools and churches from passing on "foreign" values. ${ }^{194}$ The cultural transmission of "un-American" values was particularly thought to be spread by foreign languages. ${ }^{195}$ Thus, in the years following World War I, as one legal historian reports:

Twenty-three states enacted statutes that imposed restrictions upon instruction in foreign languages, especially the German language. Many states mandated English as the exclusive language of instruction in all elementary schools. In all of these states, the prohibition applied, implicitly or explicitly, to parochial and private schools as well as to public schools. Many states further prohibited or restricted the teaching of a foreign language as a distinct curricular subject and several states specifically prohibited the teaching of the German language. ${ }^{196}$

Legislators justified these statutes by the need to protect the country from "clannish" and politically dangerous aliens, and whiteness as civilization, fitness for self-government, and the rule of law were accordingly contrasted in public opinion with images of the German nation as "antideniocratic and barbarous."197 The Supreme Court, however, thwarted these attempts to further Americanism by restricting foreign language instruction. In a series of cases decided in the 1920 s, the Court struck down several attempts to restrict or regulate out of existence foreign language instruction, whether the target was German Americans or Japanese

193. See Higham, supra note 183 , at 156-57.

194. See id. at 214 (noting that several states took action to limit suffrage to citizens only in the years immediately following World War I); id. at 222-33 (discussing the influence of nativism on spy hunting and Red hunting).

195. See generally WiLliam G. Ross, Forging NEw FREedoms: NativisM, Education, AND THE Constitution, 1917-1927 (1994); William G. Ross, A Judicial Janus: Meyer v. Nebraska in Historical Perspective, 57 U. Cin. L. REv. 125 (1988) [hereinafter Judicial Janus].

196. Ross, Judicial Janus, supra note 195, at 133 (footnotes omitted).

197. Id. at 131. For an examination of the involvement of the Ku Klux Klan in Oregon's compulsory schooling act, see David B. Tyack, The Perils of Pluralism: The Background of the Pierce Case, 74 AM. Hist. Rev. 74 (1968). 
Americans. ${ }^{198}$ Although the education cases represented a victory against nativism, the Court upheld draconian restrictions on speech and political association directed at similarly "un-American targets" during the same period. ${ }^{199}$ Meanwhile, new state enactments barred aliens from "practicing medicine, surgery, chiropractic, pharmacy, architecture, engineering, and surveying, from operating motor buses, and from executing wills." 200 In I919, Congress passed a revenue act which imposed on the first $\$ 4000$ of income of nonresident aliens a tax rate twice as heavy as that for citizens and residents of the United States. ${ }^{201}$

A second kind of legal reform comprising the new extension of race law to whites was immigration reform. Calls to limit European immigration, particularly by American workers who feared competition, were nothing new; indeed, in the late 1880 s, in response to such calls, a handful of state and federal statutes had been passed prohibiting the employment on public works of any alien who had not declared the intention to become a citizen. ${ }^{202}$ In the early twenties, however, the anti-immigration movement sought and achieved much more drastic measures. One reason may be the patriotic crisis engendered by World War I, and the concomitant loss of faith in the "melting pot."203 Another contributing factor was the widespread dissemination and popularity of eugemics. ${ }^{204}$

Eugenics was a product of racial thinking in one of its "scientific variants": the notion that heredity determined not only the physical characteristics of hunian groups, but their temperament and behavior as well. As historian Daniel Kevles notes, scientific work like that of Cesare Lombroso in criminology (identifying a "criminal type" with distinct biological, as well as behavioral, characteristics), the popularity of Social Darwinism, and the advent of Mendelian genetics in 1900 all contributed to the early-twentieth-century passion for eugenics. But the major impetus for the eugenics movement, Kevles argues, was a crisis within the social realm: the convergence of mass immigration from eastern and southern Europe; internal migration from the countryside to the city, with its resultant urban sprawl and ghetto formation; industrialization and the growth of big business; and (thanks in part to the philosophy of Plessy) the growing awareness of "the social" itself as a distinct problem for governance.

Urban Anglo-America may have always known prostitution, crime, alcoholism, and disease, but neither society had ever before

198. See Farrington v. Tokushige, 273 U.S. 284 (1927); Pierce v. Society of Sisters, 268 U.S. 510 (1925); Bartels v. Iowa, 262 U.S. 404 (1923); Meyer v. Nebraska, 262 U.S. 390 (1923).

199. See Ross, Judicial Janus, supra note 195, at 133-34.

200. Higham, supra note 186, at 301.

201. See 40 Stat. 1057; HighaM, supra note 186, at 248.

202. See Higham, supra note 186 , at 46.

203. Id. at 301.

204. See Daniel J. Kevles, In the Name of Eugenics: Genetics and the Uses of Human HEREDITY (1985). 
possessed the weight of statistical information, expanding yearly by volumes, that numerically detailed the magnitude of its problems. Statistics revealed, with seeming mathematical exactitude, that afflictions such as "mental defectiveness" and criminality were worsening every year. ${ }^{205}$

The high birthrates of poor immigrants from nonwhite and non"Nordic" countries, as well as their seeming mental inferiority ${ }^{206}$ and high rates of disease, created a panic among those Americans who now considered themselves "natives." G. Stanley Hall, psychologist and president of Clark University, worried about "the yellow and Oriental peril," warning that "the future belongs to those people who bear the most and best children and bring them to fullest maturity. They will in the end wield all the accumulated resources of civilization, and infertile races will fade before them." ${ }^{\text {"207 }}$ But the assumption of genetic differences between white Protestants of northern European "stock" and Jewish and Catholic immigrants also was cause for alarm. As Kevles reports:

A cardinal point of the American eugenics program had come to be the restriction of immigration from Eastern and Southern Europe. Eventually, the program was enlarged to permit the immigration only of pure Caucasians; to require a minimum grade of " $C$ "- the presumed average grade of the American population-on the Army intelligence-test scale; and to require certification, based on an assessment of near kin, that the prospective immigrant would become a biological asset to the United States. ${ }^{208}$

In this aim, the eugenicists were supported by a wide range of " $100 \%$ Americans" and newly burgeoning groups such as the Invisible Empire of the $\mathrm{Ku}$ Klux Klan. These perspectives were brought to fruition in the 1924 Immigration Act, which severely restricted immigration from eastern and southern Europe by limiting it to a small percentage of the foreign-born of the same national origin of inhabitants already in the country in $1920 . .^{209}$

205. Id. at 72 .

206. Here the eugenicists were able to rely on a new tool: the intelligence test. As Higham reports:

Robert M. Yerkes, President of the American Psychological Association, and the corps of distinguished psychologists who aided him in the United States Army's new psychological testing program, gathered a mass of data on the intellectual ability of Negro, native white, and foreign-born soldiers. Published after the war, their studies showed what other investigators were simultaneously learning in testing school children: that nonwhite Europeans scored almost as well as native whites, whereas soldiers born in Latin and Slavic countries averaged significantly lower. Eugenicists seized avidly on these findings as a clinching proof of the racial philosophy and of the inferiority of the new immigration.

Higham, supra note 186, at 275. See also STEPhen JAY Gould, The Mismeasure of MAN 192-99 (1981) (discussing the results of the Army examinations).

207. GouLd, supra note 206, at 73-74 (quoting G. Stanley Hall, Eugenics, Its Ideals and What It Is Going to Do, 6 ReLIGIOUS EDUC. 156 (1911)).

208. Id. at 95 .

209. Immigration Act of 1924, ch. 190, § 11(b), 43 Stat. 153, 159 (National Origins Act). "Inhabitants" of the United States did not include descendants of slave immigrants or American 
Eugenicists widely praised the bill, and President Calvin Coolidge, who signed the bill into law, had stated as Vice-President that "America must be kept American. Biological laws show . . . that Nordics deteriorate when mixed with other races."

A third kind of legal mitiative stemming from the new racialization of whites themselves consisted of new laws regulating marriage and reproduction. Here, the eugenicists' focus on reproduction led them to target the behavior of unproblematically "white" women. Freethinkers saw eugenics as necessitating greater freedom for white women, allowing them to choose careers rather than being forced into eugenically disadvantageous marriages. ${ }^{211}$ Feminist Charlotte Perkins Gilman used eugenic arguments to advocate complete sexual equality. ${ }^{212}$ But the mainstream of the eugenics movement consisted of conservatives who argued that the need to protect and further the (white) race meant that the most "fit" women should stay at home and bear as many children as possible. ${ }^{213}$

The flip side of the push to increase the numbers of the biologically fit was, of course, to decrease the numbers of the unfit. The flurry of laws passed in this period against racial miscegenation, for example, were often justified by reference to eugenics. But the eugenicists' concerns were ultimately much broader than separating white from nonwhite: they aimed to improve the white race itself. Abortion and birth control remained politically disfavored means of achieving this end. ${ }^{214}$ Instead, the eugenicists'

aborigines. See id. $\$ 11(\mathrm{~d}), 43$ Stat. at 159 . The act also prohibited Japanese immigration, gratifying whites on the West Coast who had once again fallen prey to anti-Asian hysteria. See HigHAM, supra note 186 , at 166.

210. KevLes, supra note 204, at 97 (quoting Calvin Coolidge, Whose Country Is This?, GooD HouseKeEPING, Feb. 1921, at 14). Eugenicists were not simple elitists: as Kevles notes, they "displayed no great admiration for the economic top of modern society." Rather, "[t]he eugenics movement enabled middle-and upper-middle-class British and Americans to carve out a locus of power for themselves between the captains of industry on one side and lower-income groups- both native and foreign-born-on the other." Id. at 76. Eugenicists argued for the loosening or erasure of class distinctions so that the biologically fittest could find one another and rise to the top, no matter where they happened to be born in the class structure.

211. See id. at 87 (discussing the views of George Bernard Shaw).

212. On Gilman, see Gail Bederman, Manliness and Civilization: A Cultural History OF GENDER AND RACE IN THE UNITED STATES, I 800-19I7, at 134-45 (1995).

213. This point of view was consistent with the conservatives' support of protective legislation for women in the workplace. Here again, the Court reflected popular views. In Muller v. Oregon, 208 U.S. 412 (1908), the Court, upholding such legislation against an equal protection challenge, famously held:

Even though all restrictions on political, personal and contractual rights were taken away, and [woman] stood, so far as statutes are concerned, upon an absolutely equal plane with [man], it would still be true that she is so constituted that she will rest upon and look to him for protection; that her physical structure and a proper discharge of her maternal functionshaving in view not merely her own health, but the well-being of the race-justify legislation to protect her from the greed as well as the passion of man.

Id. at 422 .

214. The notion that the state had a special interest, grounded in "racial survival," in regulating women's reproduction, however, permeated discussions of both abortion and birth control. See, e.g., People v. Gallardo, 243 P.2d 532, 536 (Cal. Ct. App. 1952) (California's anti-abortion statute is 
agenda focused on marriage restrictions, segregation by sex in institutions such as prisons and hospitals for the mentally ill, and sterilization. By 1914, thirty-odd states had enacted new marriage laws or amended old ones.

Three-quarters of the statutes declared voidable the marriages of idiots and of the insane, and the rest restricted marriage among the unfit of various types, including the feebleminded and persons afflicted with venereal disease. The ostensible ground of most of the laws was that such partners were incapable of making contracts, marital or otherwise, but in some of them, the restrictions were justified on eugenic grounds. ${ }^{215}$

In addition to marriage prohibitions, states in the first twenty years of the century instituted required delays between the application for a marriage license and the actual wedding. Like contemporary required delays for women seeking abortions, these statutes were designed to encourage people to think twice before undertaking to procreate.

While biologically fit women were at home bearing children, unfit women, particularly poor women whose lives were frequently overseen by the state, were to have a different fate. Feebleminded women, it was agreed, easily yielded to lust: they possibly had higher than normal sexual drives and certainly had poor impulse control. Between 1907 and 1917, sixteen states passed statutes giving themselves the power to compel the sterilization of persons such as habitual or confirmed criminals, epileptics, the insane, and "idiots" in state institutions. ${ }^{216}$ In a 1932 study of United States sterilization laws, Jacob Landman found that "sexual offenses or moral degeneracy figured explicitly in the grounds for sterilization found in almost half the state statutes then on the books"; in the rest, "sexual license was implicitly covered in the provisions concerning 'feeblemindedness."'217 The widespread enthusiasm for sterilization initially sparked court challenges, and several statutes were struck down on constitutional grounds. But in Buck v. Bell, ${ }^{218}$ Justice Oliver Wendell Holmes famously wrote for the Supreme Court that compulsory sterilization for an unwed mother committed to a home for epileptics and the feebleminded was constitutional:

We have seen more than once that the public welfare may call upon the best citizens for their lives. It would be strange if it could not

\footnotetext{
"predicated on the concept that the body of a woman is a holy temple" and serves the highest of purposes-"the propagation of the race"); Reva B. Siegel, Reasoning from the Body: A Historical Perspective on Abortion Regulation and Questions of Equal Protection, 44 STAN. L. Rev. 261 (1992) (discussing the historical importance of biological arguments generally in providing justification for controlling women's reproduction).

215. KeVLES, supra note 204, at 99.

216. See id. at 100.

217. Id. at 108 (quoting JacoB H. LANDMAN, Human Sterillzation 56-93 (1932)).

218. 274 U.S. 200 (1927).
} 
call upon those who already sap the strength of the State for these lesser sacrifices ... in order to prevent our being swamped with incompetence.... The principle that sustains compulsory vaccination is broad enough to cover cutting the Fallopian tubes. Three generations of imbeciles are enough. ${ }^{219}$

Although the American eugenics movement came to a rapid halt after World War II and the discovery that Nazi extermination programs were grounded in eugenicist theory, the public policy concerns in which it was grounded-including the fear that darker races are more fertile and that the most intelligent women fail to bear sufficient children to sustain the "civilized" nations-did not disappear completely from popular discourse. Indeed, the routine sterilization of women of color, especially Indian and Puerto Rican women, continued to occur well into the second half of the twentieth century. ${ }^{220}$

The new enactments subjecting whites as well as nonwhites to racial restrictions and exclusions fell for the most part outside the realm of equality. As a legal matter, successful challenges to these measures sounded in liberty principles, not equality principles. As a social matter, nativist racism and eugenics were predicated on the assumption of inequality, not mere pluralist "difference." This branch of race law, then, owes more to the law applying to nonwhite citizens than the rules of equality applicable to nonwhite citizens. The race law applicable to whites did, however, share with Plessy a philosophy of wise racial management.

Targeting populations for ever proliferating measures of normality, the racialism of eugenics reframed political problems as matters for social management (here under the rule of "scientific" expertise rather than custom or public policy) and presented social inequalities as natural. Together, decisions like Buck v. Bell and Plessy accorded legislatures great deference in preserving and improving the social body, whether the goal was managing racial heterogeneity or furthering the purity of the white race itself.

\section{Summary: The New Equilibrium}

By the 1930s, American race law was considerably more complex and extensive than it had been before the Civil War. In terms of the legal regulation of nonwhite populations, Reconstruction had deepened the split between citizens and noncitizens. Congressional plenary power over

219. Id. at 207 (citation omitted). For an examination of the spread of eugenic policies following the decision in Bell, see Jana Leslie-Miller, From Bell to Bell: Responsible Reproduction in the Twentieth Century, 8 MD. J. CoNTEMP. LEGAL Issues 123, 123-25, 129-36 (1997).

220. Although the Court restricted the use of sterilization as a punishment for crime in Skinner v. Oklahoma, 316 U.S. 535 (1942), some sterilization statutes remain on the books, and certain populations, such as poor Indian women and African American women, have been particularly hard-hit by sterilization conditioned on often coerced or uninformed "consent." See Dick Grosboll, Sterilization Abuse: Current State of the Law and Remedies for Abuse, 10 GoldEN GATE U. L. REv. 1147 (1980). 
immigration, naturalization, Indian affairs, and United States territories and possessions could be and was exercised along racial lines to keep nonwhite peoples from becoming full citizens. For those outside of the body of "We, the People," one's racial status could directly determine one's legal rights. For African Americans and other nonwhite citizens, the constitutional and statutory remnants of Reconstruction outlawed state white supremacy. Yet the willingness of the courts to take racial difference seriously and to entrust to state and local governments racial management of that difference in the "social" realm permitted both private and state action in furtherance of white exploitation, discrimination, and terror despite the promises of equality. Finally, in the early part of the twentieth century, even those of European descent became subject to racial regulation. The new nativism, incorporating racist philosophy, fostered anti-alien discrimination, immigration restrictions, and finally eugenic measures aimed at preventing unfit whites from reproducing and degrading the race. Whether consisting of "discriminations" or mere "distinctions," racial regulation was allpervasive in the age of difference.

\section{III}

\section{The Second Reconstruction and the Continuing Significance of RACE}

With the rise of eugenics, United States race law seemed to have reached a culmination. Racial difference was everywhere; and even the new constitutional order of equality had been reconciled with the drive for white hegemony. Yet the second half of the twentieth century would see yet another political and legal upheaval in race relations, one so far-reaching that it has been dubbed the "Second Reconstruction." In this second upheaval, not only the ideal of white supremacy, but even the notion of inherent racial difference itself would be exiled to the margins of political culture. The problem of preserving and furthering Euro-American "civilization"-a problem which once was discussed almost entirely in terms of race-has not disappeared; indeed, at the close of the century, public concern about the many threats (real and imaginary) posed by minority cultures, by the "Third World," by "multiculturalism," and by "diversity" has intensified. But, as the millennium ends, it is no longer acceptable in polite society to speak of white dominance (except to condemn it) or even to personally identify oneself as a member of the white race (except in ironic self-deprecation). In place of the implicit or explicit assumption that racial differences are real and necessitate government management in the "social" sphere, today the prevalent assumption is that racial differences are not real at all, but wholly arbitrary social creatures. The watchword as the century ends is "colorblindness" or, as Justice 
Antonin Scalia has interestingly put it, "[W]e are just one race here. It is American."221

Yet this shift has not been as transformative as it might seem. The public recognition that racial difference is a fiction-that the color of our skin does not determine the content of our character-is a thin veneer, beneath which lies the continued meaningfulness of race. For some, "race" continues to have meaning as a form of ethnicity or a source of political solidarity: decades of anti-Asian prejudice and discrimination in America, for example, have made it meaningful to speak of "Asian-Americans" as a distinctive social group. ${ }^{222}$ For perhaps most of us, the racial stereotypes that continue to pervade our culture still serve as a potent way of seeing the world; consciously or unconsciously, perceptions of race still make a difference. ${ }^{223}$ Finally, for a few faithful, theories of racial superiority and inferiority remain the key to human history. ${ }^{224}$

The rise of racial equality to an American creed, along with the continued social, political, cultural, and historical significance of race, has necessitated a new legal and social equilibrium. The civil rights and race "power" movements of the 1960s effected a sea change in public political culture. Racism was exposed as a moral flaw at the heart of the American condition. Yet the recognition of racism as botli fundanientally immoral and socially pervasive soon collided with the enormous implications of that recognition. Political, economic, and social institutions would have to be wholly transformed to right these wrongs, and the prospect of such upheaval threatened not only white elites but those middle-class and working white people who saw their own interests threatened by cries for black, brown, red, and yellow power. The clash between the recognition of racism and the desire to maintain privileges and entitlements formerly claimed in the name of whiteness meant that social transformation could only go so far before generating backlash. In this struggle, the argument that race makes no difference, that we are all the sanie, has not succeeded in uniting Americans against racism. Instead, many people of color have come to call for more race consciousness, not less.

Once again, the courts have played a central role in articulating this new equilibrium. The tension of the end of the twentieth century is between the egalitarian ideals of the Second Reconstruction-a fully

221. Adarand Constructors, Inc. v. Pena, 515 U.S. 200, 239 (1995) (Scalia, J., concurring).

222. See generally Yen le Espiritu, Asian American PAN-EThNicity: Bridging Institutions AND IDENTITIES (1992); Chris K. Iijima, Race as Resistance: Racial Identity as More Than Ancestral Heritage, 15 TOURO. L. Rev. 497 (1999).

223. See Linda Hamilton Krieger, The Content of Our Categories: A Cognitive Bias Approach to Discrimination and Equal Employment Opportunity, 47 STAN. L. Rev. I161 (1995).

224. For an astute assessment of various "racial projects" toward the end of the 1980 s, see John O. Calmore, Exploring Michael Omi's "Messy" Real World of Race: An Essay for "Naked People Longing to Swim Free," 15 Laiv \& INEQ. J. 25 (1997). 
"integrated" society, a society in which race makes no difference, perhaps a "diverse" society - and the pressure to leave existing political, social, and economic distributions in place where those distributions are closely linked to race. The key to managing those tensions in an age of sameness is the concept of "discrimination."

\section{A. The Destabilization of the Old Racial Equilibrium}

Although the beginming of the new era in equality law is often placed in 1954, when the Supreme Court decided Brown v. Board of Education, ${ }^{225}$ the seeds of the Second Reconstruction were sown years earlier. For example, in 1938, in a seemingly uninteresting business case, Justice Stone dropped a footnote that would decades later become the source of a new constitutional jurisprudence on civil rights. In footnote four of United States v. Carolene Products Co. ${ }^{226}$ Stone, writing for the Court, opined that "prejudice against discrete and insular minorities may be a special condition, which tends seriously to curtail the operation of those political processes ordinarily to be relied upon to protect minorities, and which may call for a correspondingly more searching judicial inquiry."227 From this footnote would spring the notion of "strict scrutiny," a notion that helped overturn the rule of Jim Crow.

The times were changing in politics as well. Two years after the decision in Carolene Products, the Democratic Party's platform pledged for the first time: "We shall continue to strive for complete legislative safeguards against discrimination in Government service and benefits, and in national defense forces. We pledge to uphold due process and the equal protection of laws for every citizen regardless of race, creed or color."228 Also in 1940, President Franklin D. Roosevelt issued an executive order forbidding racial discrimination in personnel policies for employment in the federal government, sounding the death knell for the segregationist policies of President Woodrow Wilson. ${ }^{229}$ And in the same year, under pressure from African American leaders-including A. Philip Randolph, president of the Brotherhood of Sleeping Car Porters, who was threatening a massive protest against racial discrimination in Washington, D.C.Roosevelt issued Executive Order 8802, which reaffirmed "the policy of the United States that there shall be no discrimination in the employment

225. 347 U.S. 483 (1954); see infra Part III.B.

226. 304 U.S. 144 (1938).

227. Id. at $152 \&$ n.4. The political and judicial theory behind this suggestion was developed most famously by John Ely. See generally JoHN HART ELY, DEMOCRACY AND DISTRUST: A THEORY OF Judicial ReviEw (1980) (discussing the Court's role in representative democracy).

228. Ringer, supra note 11 , at 344 (quoting P. M. BERgMan, THE Chronological History of THE NEGRO IN AMERICA 491 (1969)).

229. See id. at 342-43 (detailing how "Jim Crowism became a distinctive mark of the Wilson administration"). 
of workers in defense industries or government because of race, creed, color, or national origin. ${ }^{2230}$ President Harry S Truman accelerated the new move away from racial discrimination in the federal government: he appointed justices friendly to civil rights to the Supreme Court, created the President's Committee on Government Contract Compliance and the President's Committee on Civil Rights, and finally, in 1948, desegregated the armed forces. ${ }^{231}$ Perhaps the major turning point, however, was World War II.

With respect to the nativist branch of American race law, World War II marked a new low. During the war (despite contrary recommendations and misgivings in the War Department and in the office of the Attorney General), General DeWitt, leader of the Western Defense Command, successfully pushed through a plan to evacuate all Japanese aliens, Japanese American citizens, and alien enemies other than Japanese from the Pacific Coast. The plan was based on sheer racism. No hard evidence was ever assembled that Japanese Americans or Japanese resident aliens in fact posed any threat to national security or the war effort; indeed, many Japanese Americans of the time were "super patriots" and believers in the American Dream. Yet Senator Reynolds, chairman of the Military Affairs Committee, intoned, "Japanese consuls, Buddhist priests, and other leaders have been propagandizing the children of their countrymen for years right here beneath the shadows of the American flag, right here in the continental United States." ${ }^{232}$

The evacuation plan, when finally outlined in a memorandum to the Secretary of War, received little or no resistance. Racist anti-Japanese propaganda was flooding over the country, particularly in the West, and wartime hysteria was pervasive. As implemented, the plan escalated from an initial phase of voluntary evacuations to a second phase of conipulsory mass evacuations into "assembly centers." By August, 1942, 110,000 Japanese persons, most of them American citizens, had been forced from their homes and businesses and placed in transitional concentration camps, as a prelude to more permanent "relocation." Ten relocation centers-one each in California, Colorado, Idaho, Utah, and Wyoming, and two in Arizona and Arkansas-ultimately held the internees, some of whom did not leave the camps for three years. The last to close, Tule Lake, was not shut down until March 20, 1946. When General DeWitt proudly announced that "no precedents existed in American life" for the internment, ${ }^{233}$

230. Id. at 344-45 (quoting Civil RightS AND the BlACK AMERICAN 358 (A. P. Blaustein and R.

L. Zagrando eds., 1968)).

231. See id. at $349-51$.

232. Id. at 875 (quoting 77 CoNG. Rec. 2723 (1942)).

233. Id. at 879 (quoting U.S. ARMY, WESTERN DEFENSE COMMAND AND FourTh ARMY, FinaL REPORT: JAPANESE EVACUATION FROM THE West COAST 77 (1943)). 
he was overlooking a shameful one: the precedent of Indian removal and the Trail of Tears.

The Supreme Court offered no resistance to the Japanese internment save in scattered dissents. In Hirabayashi v. United States ${ }^{234}$ and Yasui v. United States, ${ }^{235}$ the Court unanimously upheld the convictions of Japanese American citizens for violating military curfews imposed on the basis of race. Citing the usual stereotypes about Asian "foreignness" and unassimilability, the Court found the military's racist policies to be reasonable. Nor did the Equal Protection Clause create any barrier to the military's action. Building on the suggestion of Carolene Products, the Court for the first time declared that "[d]istinctions between citizens solely because of their ancestry are by their very nature odious to a free people."236 Yet these distinctions were not unconstitutional because "tlie danger of espionage and sabotage, in time of war and of threatened invasion, calls upon the military authorities to scrutinize every relevant fact bearing on the loyalty of populations in the danger areas."237

The opinion in Korematsu v. United States ${ }^{238}$ took a similar form. In that case, Fred Korematsu was found guilty of remaining in a designated military area after the evacuation order had come into force. Once again, military necessity took precedence over the equal protection of the laws. This time several Justices dissented. Justice Murpliy, for exanıle, detailing the racial stereotypes upon which the military order rested, argued that "[a] military judgment based upon such racial and sociological considerations is not entitled to the great weight ordinarily given the judgments based upon strictly military considerations. ... I dissent, therefore, from this legalization of racism." ${ }^{239}$ In fact, as attorneys for Fred Korematsu and others who became wartime criminals for resisting the internment process later discovered, the government's attorneys in the Japanese internment cases lad hidden evidence from the Court that would have laid bare the internal dissension behind the military policy and the lack of any rationale for the race-based evacuation. ${ }^{240}$ But it would be many decades before these citizens were finally vindicated.

The aftermath of World War II also represented a new low with respect to relations between the federal government and Indian tribes.

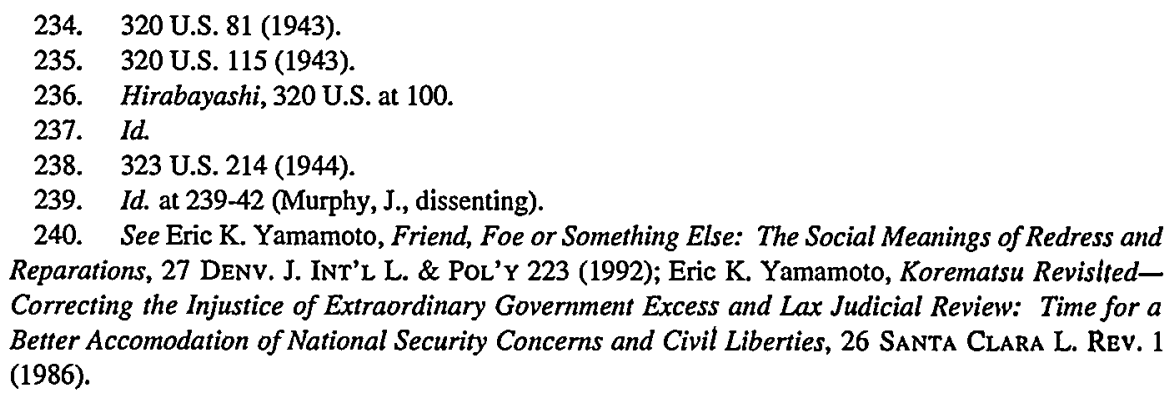
Reparations, 27 DENv. J. INx'L L. \& POL'Y 223 (1992); Eric K. Yamamoto, Korematsu RevisltedCorrecting the Injustice of Extraordinary Government Excess and Lax Judicial Review: Time for a Better Accomodation of National Security Concerns and Civil Liberties, 26 SANTA CLARA L. REv. 1 (1986). 
Government policy in the assimilation period had entailed "allotment" of Indian lands, the removal of political power over their own affairs from the tribes, the coerced destruction of Indian cultures through "Americanization" programs such as boarding schools for Indian children, the suppression of Indian spiritual practices, and, finally, as the supreme reward, American citizenship for all Indians in 1924. ${ }^{241}$ In 1934, Congress passed the Indian Reorganization Act (IRA), ${ }^{242}$ which reversed the policy of forced assimilation. Under the IRA, allotment was ended and tribes were once again encouraged to govern thenselves, albeit in the face of strong pressure froin Washington to adopt United States-style constitutions and charters. ${ }^{243}$

In 1949, however, the federal government once again did an about face. The Hoover Commission Report on Indian Affairs recommended that "'complete integration' of Indians should be the goal so that Indians would move 'into the mass of the population as full, taxpaying citizens." "244 In 1953, Congress responded with House Concurrent Resolution 108, which set forth a new policy of "termination." ${ }^{245}$ Termination, which was implemented by statute on a tribe-by-tribe basis, was nearly as ominous as it sounds. It meant ending federal protections against the sale of land and against state taxing authority, imposing state legislative and judicial jurisdiction over Indians, and ending tribal sovereignty. In soine cases, reservation land was simply sold off to the highest bidder and the tribal meinbers received checks for their shares. Tired of its "wards," Congress had decided to declare thein Americans and set thein loose. ${ }^{246}$

With respect to the nativist strain of American race law affecting nonwhites, then, World War II and the immediate post-war period represented a new low. ${ }^{247}$ Yet in the wake of World War II, the system of racial caste that constituted the second inajor branch of American race law was suddenly vulnerable to challenge.

The end of the war sparked a new activisin in groups considered nonwhite. Returning African American and Mexican American troops found Jim Crow inpossible to stoinach after having served their country with honor and distinction, and often after having been treated as equals by

241. See Indian Citizenship Act of June 2, 1924, ch. 233, 43 Stat. 253 (codified at 8 U.S.C. \& 1401(b) (1994)). See generally, ROBERT N. Clinton ET AL., AMERICAN INDIAN LAW: CASES AND Materials 147-152 (3d ed. 1991) (describing the "Allotment Period").

242. Indian Reorganization Act of June 18, 1934, (Wheeler-Howard Act), ch. 576, 48 Stat. 984 (codified at 25 U.S.C. $\$ \S 461-479$ (1994)).

243. See Clinton ET AL., supra note 241, at 152-55 (describing the "Reorganization Period").

244. Getches \& WiLkinson, supra note 95, at 130 (citation omitted).

245. See Clinton ET AL., supra note 241, at 155-58 (describing the "Terminantion Period").

246. See id.

247. The nativist strain of race law governing whites had already lost considerable steam after the 1924 Immigration Act was passed. See HIGHAM, supra note 186, at 325-30 (describing the waning of American nativism in the latter half of the 1920s). 
white Europeans. ${ }^{248}$ In the post-war period, anti-racist activists, working both through local, grass roots groups and national organizations like the League of United Latin American Citizens (LULAC) and the National Association for the Advancement of Colored People (NAACP) began to campaign vigorously to end American apartheid.

The discourse of race science was also newly vulnerable to challenge. The discovery of the full extent of the Holocaust, and Hitler's theories of racial purity that purported to justify it, chilled the enthusiasm for American eugenics programs. Indeed, race science generally fell from favor after the war. In the wake of World War II, the United Nations was established to promote "universal respect for, and observance of, human rights and fundamental freedoms for all without distinction as to race, sex, language, or religion."249 The United Nations Economic and Social Council (UNESCO) took on the task of eliminating racism by bringing scientific findings about the falsity of race to the attention of the public, and to this end published statements and studies by prominent scientists debunking race science. ${ }^{250}$ Theories of biological racial inferiority were now on the defensive.

After World War II, decolonization also accelerated around the globe. The empires built by powers such as England, France, and Portugal began to crumble as country after country rose up to assert its independence and throw off European domination. These newly independent nations rejected the doctrines of white supremacy that had been used to justify their exploitation. Nevertheless, racial segregation in the United States was based on just such doctrines. If America wanted to win the allegiance of these new nations, it would have to do something about its own "internal

248. Gilbert Paul Carrasco tells one representative story:

In Texas, a funeral parlor in Three Rivers refused to bury Félix Longoria, an American soldier decorated for heroism, because he was of Mexican descent. This obviously racist action sparked a storm of controversy that ended with the intervention of then Texas Senator Lyndon B. Johnson, who secured burial for Longoria in Arlington National Cemetery. Sergeants José Mendoza López and Macario García, each awarded the Congressional Medal of Honor, were refused service in restaurants and diners because of their Mexican heritage.

Sergeant García, however, decided to challenge such discrimination against Latinos. García, after being told that be would not be served because he was a "Mexie," admonished the proprietor to serve him, declaring, "[If I aml good enough to fight your war for you, I'm good enough for you to serve a cup of coffee to." The merchant in charge of the diner refused to serve García and went so far as to attempt physically to remove García from the diner. García defended himself. The altercation ended with the arrival of the police. The police sent everyone home and ordered the diner closed for the night to end the incident. Later, after the incident was recounted over the national news, Sergeant García was arrested and charged with aggravated assault in an attempt by the city to save face.

Carrasco, supra note 88, at 196.

249. U.N. CHARTER art. 55(c).

250. See JACOBSON, supra note 45, at 102 (citing UNESCO, THE RACE CONCEPT: ResulTs OF AN INQUIRY (1952)). 
colonialism." The changing geopolitical situation left the United States system of racial caste newly vulnerable. ${ }^{251}$

Between the late 1940s and the late 1960s, antiracist activists-most notably those in the African American civil rights and "Black Power" movements-successfully cultivated the seeds of antidiscrimination law found in cases like Carolene Products and even in Plessy itself. Their legal and political efforts, combined with a massive grass roots social movement of a scale and moral power not seen since abolitionisin, and coupled with the new political and social vulnerability of racial segregation and discrimination, eventually forced the United States into a political crisis. The outcome of that crisis was the so-called Second Reconstruction: a movement within both Congress and the Supreme Court to uproot de jure racial segregation, to create new legal tools to fight discrimination, and to breathe new life into the long-forgotten remnants of the First Reconstruction.

\section{B. The Elements of the Second Reconstruction}

The story of the Second Reconstruction is well known to most readers. During these tumultuous decades, African American, Latino, Indian, and Asian American activists, working alongside people of all races, were able to call public attention to-and transform public opinion on- the racism that had created, in the words of the Kerner Commission, "two societies ... separate and unequal." 252 Legally, the Second Reconstruction consisted of three elements: civil rights law from the First Reconstruction, new legislation from Congress, and a withdrawal from various doctrines of plenary power. I will discuss each of these in turn.

\section{Civil Rights Law from the First Reconstruction}

The first element of the Second Reconstruction was civil rights law dating from the First Reconstruction. From the late 1930s to the late 1960s, the Supreme Court returned to the remnants of the First Reconstruction and

251. See Mary L. Dudziak, Desegregation as a Cold War Imperative, 41 STAN. L. REv. 61 (1988).

In the years following World War II, racial discrimination in the United States received increasing attention from other countries. Newspapers throughout the world carried stories about discrimination against non-white visiting foreign dignitaries, as well as against American blacks. At a time when the U.S. hoped to reshape the postwar world in its own image, the international attention given to racial segregation was troublesome and embarrassing. The focus of American foreign policy at this point was to promote democracy and to "contain" communism. However, the international focus on U.S. racial problems meant that the image of American democracy was tarnished. The apparent contradictions between American political ideology and practice led to particular foreign policy difficulties with countries in Asia, Africa and Latin America. U.S. government officials realized that their ability to sell democracy to the Third World was seriously hampered by continuing racial injustice at home. Accordingly, efforts to promote civil rights within the United States were consistent with, and important to, the more central U.S. mission of fighting world communism.

Id. at 62-63.

252. Report of the National Advisory Committee on Civil Disorders (1968). 
breathed new life into provisions that had been functionally dead for years, including the Equal Protection Clause of the Fourteenth Amendment and the remaining pieces of the Reconstruction civil rights acts such as 42 U.S.C. sections 1981,1982 , and $1983 .^{253}$ The best-known story here involves the fight against segregated schools undertaken by the NAACP, which ultimately achieved the overruling of Plessy in Brown v. Board of Education. ${ }^{254}$ Brown considered the constitutionality of racial segregation between blacks and whites in elementary and secondary schools in Kansas, South Carolina, Virginia, and Delaware. Writing for a unanimous Court, Chief Justice Earl Warren held that racial segregation was "inherently unequal."

The decision in Brown would come to be identified as the central legal and political moment in the destruction of the American racial caste system. Despite the violent backlash that followed the decision, ${ }^{255}$ and the ensuing decades of uncertain progress in the actual desegregation of schools, Brown signaled the moral and political bankruptcy of racial segregation as a way of life. The decision in Brown was followed in short order by a series of per curiam opinions in which the Court, citing Brown,

253. 42 U.S.C. $\$ 1981$ (1994) (extending to all persons within the jurisdietion of the United States the same right to make and enforce contracts, to sue, be parties, and give evidence as white citizens); 42 U.S.C. $\$ 1982$ (1994) (extending to all citizens of the United States the same property rights as those enjoyed by white citizens); 42 U.S.C. $\$ 1983$ (1994) (creating a federal civil private right of action to persons whose constitutional or statutory rights are violated under color of law).

254. This story conventionally focuses on African Americans, but Mexican Americans playcd an important, if little-known, role as well. As far back as 1931, the Mexican parents of Lemon Grove, California, had won a superior court case to desegregate the public schools of that town, but the decision had no precedential value. See Christopher Arriola, Knocking on the Schoolhouse Door: Mendez v. Westminster: Equal Protection, Public Education, and Mexican Americans in the 1940's, 8 LA RAZA L.J. 166, 182 (1995).

Seven years after the Lemon Grove victory, in Missouri ex rel. Gaines v. Canada, 305 U.S. 337 (1938), the NAACP successfully argued to the Supreme Court that Missouri was not providing "equal" facilities to an African American law student who was sent out of state because no "black" law school existed within the state. Despite the ruling, Missouri avoided integration by hastily establishing such a school. See Bluford, The Lloyd Gaines Story, 1958 J. Educ. Soc. 242, 245-46 (1959). These initial successes were followed by Westminster v. Mendez, 161 F.2d 774 (9th Cir. 1947) (striking down segregation of Mexican American school children in California); Sipuel v. Board of Regents, 332 U.S. 631 (1948) (holding that the state was obligated to provide a blaek student with an equal legal education); Sweatt v. Painter, 339 U.S. 629 (1950) (requiring that a black student be admitted to the University of Texas Law School, rather than being forced to enroll in a new and clearly inferior "black" law school); McLaurin v. Oklahoma State Regents, 339 U.S. 637 (1950) (holding that the University of Oklahoma could not keep a black graduate student from studying, taking classes, and eating with the other students by giving him special designated desks and a special mealtime); and finally Brown $v$. Board of Education, 347 U.S. 483 (1954) (holding that racial segregation in elementary education, contrary to Plessy, was "inherently unequal"). See also Bolling v. Sharpe, 347 U.S. 497 (1954) (holding that segregation in the Distriet of Columbia public schools violated the equal protection component of the fifth amendment due process clause). For an engrossing account of the campaign that eulminated in Brown v. Board of Education, see RICHARD KLUGER, SIMPLE JUSTICE: THE HISTORY OF BROWN V. BOARD OF EDUCATION AND BLACK AMERICA's STRUGGLE FOR EQUALITY (1976).

255. See RINGER, supra note 11 , at $431-40$. 
extended the rule, striking down racial segregation in restaurants, interstate bus terminals, public carriers, public parks, beaches, municipal golf courses, cafeterias, and auditoriums. ${ }^{256}$

Following World War II, the Supreme Court also drastically reduced government power over racial management in the old "social" realm. In a series of cases concerning voting discrimination, the Court struck down state attempts to exclude African Americans from political power by "privatizing" the electoral process. ${ }^{257}$ The Court began to find state action when governments colluded with privately owned companies to provide discriminatory services. ${ }^{258}$ The Court undermined the practice of writing racially restrictive covenants to protect all white neighborhoods by making them legally unenforceable in Shelley $v$. Kraemer ${ }^{259}$ and Barrows $v$. Jackson. ${ }^{260}$ The Court restricted the states' ability to persecute civil rights organizations and civil rights demonstrators in several important First Amendment cases. ${ }^{261}$ Finally, the Court entered the heart of the "social" realm, and held antimiscegenation statutes unconstitutional in Loving $v$. Virginia. ${ }^{262}$ White purity was no longer a state interest of constitutional significance.

The fall of Jim Crow was accompanied by new constitutional restrictions on the power of the police to maintain racial order. The beginning of this trend, again, lies back in the late 1930s when, in Brown $v$. Mississippi, ${ }^{263}$ the Court for the first time excluded a coerced confession from evidence based on the Fourteenth Amendment Due Process Clause. ${ }^{264}$ The Warren and Burger Courts of the 1950s to the 1970s, however, moved

\footnotetext{
256. See id. at 312-13.

257. See, e.g., Terry v. Adams, 345 U.S. 461 (1953); Smith v. Allwright, 32 I U.S. 649 (1944).

258. See, e.g., Burton v. Wilmington Parking Auth., 365 U.S. 715 (1961) (holding that a private restaurant leasing a parking garage from the state was bound by the Equal Protection Clause). But see Moose Lodge No. 107 v. Irvis, 407 U.S. 163 (1972) (finding no state action in refusal of lodge to serve food and liquor to black people, although lodge held a state hiquor license).
}

259. 334 U.S. 1 (1948).

260. 346 U.S. 249 (1953).

261. See, e.g., NAACP v. Claiborne Hardware Co., 458 U.S. 886 (1982) (holding that the NAACP and individuals cannot be held liable for business losses resulting from a civil rights boycott unless losses result from intentional violent activity); Shuttlesworth v. Birmingham, 394 U.S. 147 (1969) (overturning conviction for leading civil rights march without a permit when licensing ordinance is worded in vague, general terms); NAACP v. Alabama ex rel. Patterson, 357 U.S. 449 (1958) (holding that the NAACP cannot be compelled to disclose the names of its Alabama members to the state). But see Waller v. City of Birmingham, 388 U.S. 307 (1967) (holding that civil rights marchers must obey injunction denying permission to demonstrate even where denial may be unconstitutional).

262. 388 U.S. 1 (1967). During this period as well, state supreme courts began to hold unconstitutional the anti-Asian land laws. See Fujii v. California, 38 Cal.2d 718 (1952) (California's land law); Namba v. McCourt, 185 Or. 579 (1949) (Oregon's land law). Washington repealed its land law by statute in 1967. See 1967 Wash. Laws, ch. I63, § 7.

263. 297 U.S. 278 (1936).

264. In that case, several prisoners had been beaten into confessing. The deputy who presided over the beatings agreed that one prisoner had been whipped, but "[n]ot too much for a negro; not as much as $\mathbf{T}$ would have done if it were left to me." Id. at 284. 
into criminal law and procedure with a vengeance. For example, in Papachristou v. City of Jacksonville, ${ }^{265}$ the Court struck down a municipal loitering ordinance as "void for vagueness." Noting in its opinion that most of the petitioners who had been prosecuted under the ordinance were either African Americans or members of interracial social gatherings, the Court emphasized the importance of fair notice and the need to prevent "unfettered discretion" in the hands of the police. ${ }^{266}$ In this period as well, the Court announced new constitutional limitations on the search and seizure of suspects, ${ }^{267}$ extended the Sixth Amendment right to jury trial ${ }^{268}$ and the Sixth Amendment right to counsel ${ }^{269}$ to the states, extended the exclusionary rule to state courts, ${ }^{270}$ and protected a criminal defendant's right to refuse to testify in court. ${ }^{271}$ Most importantly, the Court issued a series of rulings limiting police power over the interrogation of suspects, culminating in Miranda $v$. Arizona, ${ }^{272}$ in which the Court held that statements derived from the custodial interrogation of a defendant are excluded from evidence unless specific procedures had been followed to guarantee the defendant's constitutional rights. ${ }^{273}$ These restrictions on police discretion made it increasingly difficult for the police to act as the enforcement arm of white supremacy.

Finally, the Warren Court resuscitated the remnants of the Reconstruction civil rights statutes after their long sleep. In 1961, the Court held that victims of police brutality could state a claim for relief based on 42 U.S.C. section 1983, because such brutality constituted action "under color of state law" within the meaning of the statute..$^{274}$ In 1968, in Jones $v$. Alfred H. Mayer Co. ${ }^{275}$ the Court revived 42 U.S.C. section 1981, prohibiting racial discrimination in contracts; the Court would later extend the protections of section 1981 to private as well as public contracts, and

265. 405 U.S. 156 (1972).

266. Id. at 167.

267. See, e.g., Terry v. Ohio, 392 U.S. 1 (1968) (announcing "stop and frisk" rule); Rochin v. California, 342 U.S. 165 (1952) (subjecting defendant to forced stomach pumping to extract evidence of drug use "shocks the conscience" and violates the Fourteenth Amendment Due Process Clause).

268. See Duncan v. Louisiana, 391 U.S. 145 (1968).

269. See Gideon v. Wainwright, 372 U.S. 335 (1963). For a full account of this casc, sec generally ANTHONY LEWIS, GIDEON'S TRUMPET (1964).

270. See Mapp v. Ohio, 367 U.S. 643 (1961).

271. See Griffin v. California, 380 U.S. 609 (1965).

272. 384 U.S. 436 (1966).

273. See also Escobedo v. Illinois, 378 U.S. 478 (1964) (describing a defendant's "absolute constitutional right to remain silent"); Massiah v. Unitcd States, 377 U.S. 201 (1964) (holding that a defendant's right to counsel was violated when admissions were surreptitiously obtained after indictment and in the absence of counsel).

274. See Monroe v. Pape, 365 U.S. 167 (1961).

275. 392 U.S. 409 (1968). 
section 1982, which prohibits private discrimination in transactions involving property. ${ }^{276}$ The rule of Jim Crow was coming to an end.

\section{The Second Reconstruction in Congress}

Although Congress had passed some scattered statutes (largely ineffectual) in 1957 and 1960 concerning minority voting rights, ${ }^{277}$ the explosion of new legislation usually identified with the Second Reconstruction did not come about until the grass roots movement for civil rights had created a political crisis, forcing both the executive branch and the legislative branch to respond. As white resistance to Brown hardened in the Deep South, civil rights organizations such as the Student Nonviolent Coordinating Committee (SNCC), the Congress of Racial Equality (CORE), and the Southern Christian Leadership Conference (SCLC) accelerated their political strategies aimed at turning white America against itself. Armed with the philosophy of nonviolence and the rhetoric of justice, equality, and common humanity, African Americans began to directly challenge white supremacist practices in the South. Their challenge increasingly won the sympathies of Americans of all races. Voting registration drives, "freedom schools," economic boycotts, and appeals to Christian principles helped mobilize and radicalize African Americans, as well as whites who jomed the movement in solidarity. Nonviolent protests, demonstrations, and marches provided a series of dramatic tableaux in which the violent, hateful face of white racism was pitted against the peaceful, prayerful faces of African American resistance. As the disorder escalated throughout the South, the rest of America was forced to observe racial domination in action. ${ }^{278}$

Spontaneous acts of violent resistance im black cities of the North and West soon joined forces with the nonviolent resistance in the South. In 1964, riots exploded in black neighborhoods of New York City, Jersey City, Chicago, and Philadelphia. In August, 1965, after the police allegedly used excessive force in a routine traffic arrest, the city of Los Angeles came to a standstill for days as African Americans firebombed and looted businesses in Watts. The governor ordered in National Guardsmen who proceeded to shoot anyone suspected of being a sniper. The Watts riot shocked those whites who had been inclined to think black resistance was a purely Southern phenomenon, and spawned a national commission (the "Kerner Commission") whose report concluded that the riots were not

276. See Runyon v. McCrary, 427 U.S. 160 (1976).

277. See RINGER, supra note 11 , at 325-27.

278. See generally Taylor Branch, Parting the Waters: America in the King Years, 1954-63 (1988); TAYLoR BRANCh, Pillar of Fire: AMERICA IN THE KING Years, I963-65 (1998). 
senseless hooliganism, but rather constituted a conscious political protest against African American subordination. ${ }^{279}$

Urban rioting continued through that year and into 1966 and 1967. Cleveland, Cincinnati, Tampa, Buffalo, Newark, Syracuse, New Haven, Providence, Wichita, Washington, D.C. and Detroit, among other cities, all went up in flanies. Under intense pressure from these domestic rebellions, Congress and President Lyndon Johnson needed to rally the rest of the world to America and against the USSR and China. This pressure helped shape the remaining legislation of the Second Reconstruction.

The Civil Rights Act of $1964,{ }^{280}$ originally proposed by President Kennedy, created new protections for a broad range of rights in both the political and the old "social" arena. Title I, for example, required universalistic criteria for voting; Title II used the national commerce power to prohibit discrimination in public accommodations; Titles III and IV desegregated public facilities, including public educational facilities; Title VI prohibited discrimination in all federally funded programs. Title VII broke important new ground by prohibiting "private" employment discrimination for the first time, whether based on race, color, sex, religion, or national origin. In addition to creating private rights of action to enforce the Act, Congress created a new federal agency, the Equal Employment Opportunity Commission (EEOC), and gave it the power to investigate complaints and issue regulations under the Act. Several years later the EEOC received the power to institute civil actions on its own. ${ }^{281}$

The Voting Rights Act of 1965 (prompted by President Johnson, who quoted the civil rights anthem "We Shall Overcome" in his message to a joint session of Congress) finally put teeth into federal voting law. For exaniple, it placed under federal oversight several states and other governmental subdivisions which had been the worst offenders against black voting rights, and suspended qualifying tests in these areas. The Act had an immediate and dramatic effect on minority voting and political participation, bringing thousands of citizens into electoral politics for the first time. Not since the First Reconstruction had so many African Americans registered to vote. ${ }^{282}$

Finally, in the Fair Housing Act of 1968, Congress addressed a key element of racial domination in both the North and the South: racial segregation of public and private housing. Here, however, the law made only timid inroads; the statute only authorized the Department of Housing and Urban Development (HUD) to use informal methods of persuasion to stop

279. See RINGER, supra note 11 , at 479 .

280. Civil Rights Act of 1964, 78 Stat. 241 (codified at 28 U.S.C. $\S \S 1447,42$ U.S.C. $\S 1971$, 1975(a)-1975(d), 2000(a)-2000(h)(6) (1994)).

281. See RINGER, supra note 11 , at 332 .

282. See KouSSER, supra note 40 , at 13 (describing dramatic success of the Voting Rights Act). 
discriminatory practices, and resistance to enforcement was widespread in both government and the private sector. ${ }^{283}$

Congressional action was supplemented by action in the executive branch and in federal agencies. Executive Order 10925, signed by President Kennedy, for the first time directed contractors with the federal government not merely to proclaim equal opportunity for all qualified persons, but to take "affirmative action" to ensure that discrimination did not in fact occur; noncompliance could mean suspension or termination of the contract. ${ }^{284}$ Kennedy's committee also developed a compliance reporting system to monitor the results of the equal opportunity mandate. President Johnson continued the work begun by Kennedy when, in 1965, he abolished the Kennedy committee and put the authority for carrying out the new nondiscrimination and affirmative action policies in the Department of Labor, a well-established bureaucracy with substantial power. ${ }^{285}$ In 1968 , the Labor Department's new Office of Federal Contract Compliance (OFCC) promulgated a new code that required contractors and large subcontractors to develop "affirmative action plans" with goals and timetables for hiring. President Nixon's adiministration would later refine these requirements by creating numerical guidelines for hiring based on the concept of "underutilization." action programs, both voluntary and mandatory, contributed to a surge of people of color into areas of employment and higher education from which they had previously been excluded.

In contrast to the hostility of the Supreme Court to the legislation of the First Reconstruction, the liberal Court of the 1960s and early 1970s largely sustained the new statutory Reconstruction. For example, in Katzenbach v. McClung ${ }^{287}$ and Heart of Atlanta Motel, Inc. v. United States, ${ }^{288}$ the Court rejected constitutional attacks on Title II of the 1964 Act; in South Carolina v. Katzenbach ${ }^{289}$ and Katzenbach v. Morgan, ${ }^{290}$ the Court upheld the Voting Rights Act of 1965. The principles of states' rights and a limited national government that had been used to defeat the first congressional Reconstruction were themselves undermined in the second.

Between judicial, congressional, and executive action from the $1940 \mathrm{~s}$ through the $1960 \mathrm{~s}$, then, the old compromise in race law between

283. See John O. Calmore, Race/ism Lost and Found: The Fair Housing Act at Thirty, 52 U. Mrami L. Rev. 1067 (1998).

284. See RINGER, supra note 11 , at 359 .

285. See id. at 366.

286. See id. at 377.

287. 379 U.S. 294 (1964).

288. 379 U.S. 241 (1964).

289. 383 U.S. 301 (1966).

290. 384 U.S. 641 (1966). 
principles of equality and the reality of racial hierarchy was destroyed. Federal power had invaded the previously sacrosanct area of "the social" and disrupted the authority of state action, local government action, and state enforced "private" action over race relations. It looked as if the era of merely formal equality was over.

\section{The Retreat of Plenary Power}

The third element of the Second Reconstruction was Congress's renunciation of its plenary power to exclude groups of people from citizenship based on race, and its renunciation of the "termination" policy that had left Indian nations without any legal recognition or protection. As with civil rights, the first changes began in the 1940s, as the United States felt compelled to portray itself as a land of freedom and equality in light of decolonization and the Cold War. In 1943, the Chinese Exclusion Acts were repealed, ${ }^{291}$ and in 1946, subcontinental Indians and Filipinos were made racially eligible for naturalization. ${ }^{292}$ In 1947, the Japanese American Citizens' League (JACL) targeted immigration reform as its primary cause, and its lobbying efforts began to pay off. In 1952, for example, Congress passed the McCarran-Walter Act, which abolished the Asiatic Barred Zone. The new act still limited immigration within the Asian Pacific triangle to a quota of only two thousand per year and expanded the categories of excludable and deportable aliens. ${ }^{293}$ But in 1965 the JACL and other activist groups had their greatest victory: Congress heeded President Kennedy's call to abolish the 1920s immigration system based on the desirability of certain nationalities. The new amendments allowed twenty thousand immigrant visas for every country not in the Western Hemisphere, reserving most for family reunification but also establishing occupational preference categories and a category for persons fleeing a Communist or Communist-dominated country. ${ }^{294}$ Since 1965, Asian American communities have grown dramatically. ${ }^{295}$

The "wards of the Nation," the first group America had targeted for extermination on the basis of race, were the last to succeed in forcing positive change in the post-World War II period. Two new activist groups-the National Indian Youth Council, founded in 1961, and the American Indian Movement (AIM), founded in 1968-exemplified a new spirit of defiant protest that linked Indians from different tribes together in political

291. See The Chinese Repealer, 57 Stat. 600 (Dec. 17, 1943).

292. See Filipino and Indian Naturalization Act, 60 Stat. 416 (July 2, 1946).

293. See Immigration and Nationality Act of 1952, Pub. L. No. 414, 66 Stat. 163 (June 27, 1952). See generally Bill Ong Hing, Making and Remaking Asian America Through Immigration PoLICY I850-1990, at 39 (1993) (discussing unhappiness expressed by Presidents Truman, Eisenhower, and Kennedy with the national origins system).

294. See 8 U.S.C. §§ 1151-1153.

295. See HiNG, supra note 293, at 118. 
struggle against federal and state governments. The new "Red Power" movement was driven both by the desperate material conditions in which many reservation and urban Indians lived in the wake of "termination"extreme poverty, hunger, alcoholism, violence, and vicious white ra$\mathrm{cism}^{296}$ - and by the desire, like the desire reflected in the "Black Power" movement, for cultural and spiritual rebirth. ${ }^{297}$

Red Power was manifested in practices undertaken to serve and heal Indian communities and to forge new links between tribes, between urban and rural Indians, and between older traditional people and a new breed of college-educated, radical young people. For example, AIM began its organizational life by creating social services and legal rights programs to prevent and challenge police abuse and to help Indians find jobs and housing, and by founding a "survival school" to teach young people about Indian history and culture. ${ }^{298}$ But its opposition to the colonial practices of the Bureau of Indian Affairs and to those official "Indian leaders" seen as complicit with exploitative practices and policies, and its call for cultural pride and political sovereignty, quickly brought the movement into conflict (sometimes violent) with law enforcement and with state and federal governments. In one of the most fanious incidents of direct action, for example, a group of about one hundred Indians calling themselves "Indians of All Tribes" occupied Alcatraz Island in San Francisco for nineteen months, from 1969 to 1971 . The occupying force held press conferences and powwows, issued proclamations, and negotiated with federal officials for possession of the island to establish Indian educational and cultural centers. ${ }^{299}$ Although the negotiations eventually collapsed, the end of the occupation in 1971 sparked nearly a decade of intense activism, including a number of other occupations of federal lands and government buildings around the country and mass protests such as the "Trail of Broken Treaties," a crosscountry march from California to Washington D.C. in the fall of 1972 , timed to arrive in Washington just before the United States presidential election. ${ }^{300}$

296. Peter Matthiessen asserts, for example, that AIM "came into existence as a direct result of the termination and relocation programs that dumped thousands of bewildered Indians into the cities," whereupon they faced job discrimination and struggled for decent housing and access to education. Peter Matthiessen, In the Spirit of Crazy Horse 35 (1983).

297. See Red Power: The American Indians' Fight for Freedom 6 (Alvin M. Josephy Jr. et al. eds., $2 d$ ed. 1999) (1971) (arguing that since the 1960s, "[t]he militancy and legal sophistication of Indian leaders has been strengthened and deepened by a reaffirmation of the centrality of spirituality and a recommitment to native traditions").

298. See MATTHIESSEN, supra note 296 , at 36.

299. See RED Power, supra note 297, at 39.

300. See id. at 44; see also id. at 53 (describing "The Longest Walk," a 1978 march from California to Washington undertaken to call attention to the forced removal of Indians from their homelands and the growing backlash against Indian treaty rights). 
The legal response to Red Power was long in coming, but in the 1970s the tide at last turned toward Indian self-determination. In 1970, President Nixon issued a special Presidential Message to Congress on Indian Affairs, denouncing both the termination policy and the paternalistic attempts at forced assimilation that had preceded it, and proclaiming executive support for a new federal policy based on Indian self-determination. ${ }^{301}$ This message was followed by a series of new federal statutes passed in the 1970s that reversed the termination policy and promoted self-determination. Some of these statutes remstated the tribes that had been "abolished" under termination; ${ }^{302}$ others granted new power to all Indian tribes to take charge of reservation economic and social programs, free from supervision and control by the Bureau of Indian Affairs. ${ }^{303}$ Under the new policy of selfdetermination, "[r]eservation communities are developing tribal court systems, establishing tribal education systems including tribal colleges, extending tribal sovereignty and control over resources and taxation, securing and enforcing tribal hunting, fishing, and water rights, and building tribal economic development programs, most recently in the areas of gaming, natural resources, and recreation., ${ }^{304}$

\section{The Empire Strikes Back: Elements of Social Resistance to the Second Reconstruction}

The Second Reconstruction, social and legal, brought about a sea change in the public discourse on race. Racism and white supremacy were recognized as moral wrongs of the first order. The United States finally came to embrace the message of humanist antiracism symbolized by the speeches of Martin Luther King, Jr. Despite the defiance of a few states, the federal government even established Martin Luther King Day as a national holiday. And in the condemnation of white supremacy and racist ideology, white identity itself became newly suspect. Although just a decade earlier, white politicians and public citizens spoke out publicly about

301. See id, at 101.

302. See, e.g ., Pub. L. No. 91-500, 84 Stat. 1096 (Dec. 15, 1970) (returning Blue Lake and 48,000 acres of land in New Mexico to the Taos Pueblos); Alaska Native Claims Settlement Act of 1971, Pub. L. No. 92-203, 85 Stat. 688 (Dec. 18, 1971) (recognizing the land rights of Alaska natives and providing for mineral royalties payments and land transfers to tribes in Oregon and Arizona); Menominee Restoration Act of 1973, Pub. L. No. 93-197, 87 Stat 770 (Dec. 22, 1973) (codified at 25 U.S.C. $\$ 903(a)-903(f)(1994))$.

303. See, e.g., Indian Self-Determination and Education Assistance Act of 1975, Pub. L. No. $93-$ 638 , 88 Stat. 2203 (releasing Indians from BIA control over economic, social, and political activities on reservation lands); Indian Child Welfare Act of 1978, Pub. L. No. 95-608, 92 Stat. 3069 (creating priorities for the placement of Indian children in foster or adoptive homes that favored native over nonnative families; see also American Indian Religious Freedom Act, U.S. Congress Joint Resolution 102 (Aug. 11, 1978) (proclaiming American Indians' "inherent right of freedom to believe, express, and exercise [their] traditional religions . . . including but not limited to access to sites, use and possession of sacred objects, and the freedom to worship through ceremonials and traditional rites").

304. RED POWER, supra note 297, at 5. 
the need to protect and preserve the purity and the dominance of the white race, by the 1980s such talk had become anathema in public, even in the Deep South. ${ }^{305}$ Whiteness was no longer a mark of pride; indeed, in some quarters white identity had become a mark of shame. "Integration" and, later, "diversity" had replaced "separate development" as the dominant racial ideal. Yet the Second Reconstruction failed to bring about a truly integrated America. Indeed, several commentators have argued that the "seeds of backlash" were sown within the Second Reconstruction itself. By 1981, for example, historian Eric Foner declared that a second period of "Redemption" was underway. ${ }^{306}$

One cause of the new redemption was the economic recession that hit the United States in the mid-1970s, and the beginning of a longer-term restructuring of the economy that would give birth to a new, and large, "anxious class." Th07 The buoyant, seemingly endlessly expanding economy of the 1960s had been able to support the entry of new competition into the labor market. In the 1970s, the country entered a period of belt-tightening, anxiety, and suspicion. Even after President Ronald Reagan declared it "Morning Again in America," 308 economic turmoil persisted. Since the early 1970s, real wages have stagnated or declined. In response, Americans are working harder than ever. Because it increasingly takes two paychecks to sustain married households, women are flooding into paid employment, and in all types of households, Americans are working longer and longer hours. ${ }^{309}$ In addition, although unemployment levels in the 1990 s were low and the rate of new job creation high, full-time jobs that pay a "family wage" are being rapidly replaced by part-time and temporary jobs that carry lower wages and fewer benefits. ${ }^{310}$ Income and wealth disparity in the United States rose dramatically in the 1980s: while the poorest people in the nation grew poorer, the rich got much, much richer. ${ }^{311}$

305. This was not to be a permanent state of affairs, however. In 1989, David Duke of Louisiana, a former Grand Wizard of the Knights of the Ku Klux Klan and head of the National Association of White People, was elected to the Louisiana House of Representatives; he received 44 percent of the vote in the 1990 Louisiana senatorial primary. See ThOMAS BYRNE EDSALL \& MARY EDSALL, ChaIN REACTION: THE IMPACT OF RACE, RightS AND TAXES ON AMERICAN POLITICS 114 (1991).

306. RINGER, supra note 11, at 1101 (quoting ERIC FONER, REDEMPTION II 23 (1981)); Calmore, supra note 224.

307. See Louis Uchitelle, Changing Economy Spawns "Anxious Class," S.F. Chron., Nov. 21, 1994, at A6.

308. See Frances Fitzgerald, Way Out There in the Blue: Reagan, Star Wars, and the END OF THE COLD WAR 233 (2000).

309. See generally Juliet Schor, The OVERWORKEd AMerican: The UnEXPECTEd DeCliNe of LEISURE (1991) (investigating why the American workweek has gotten longer in recent years).

310. See Kenneth Karst, The Coming Crisis of Work in Constitutional Perspective, 82 CoRnelL L. REv. 523, 525-26 \& n.10 (1997).

311. See, e.g., Simon Head, The New, Ruthless Economy, N.Y. Rev. Books, Feb. 29, 1996, at 47; Kenneth Karst, supra note 310. 
One consequence of these economic changes has been the development of a new group of people so intensely impoverished that it has been called the "underclass." Not surprisingly, this group is disproportionately African American and Latino. ${ }^{312}$ A second consequence of the new economic insecurity has been a revival of nativist racism in the 1980s and 1990 s, expressed in popular rhetoric, hate violence, and exclusionary legal policies directed at low-wage immigrants in general and Mexicans and Asians in particular. ${ }^{313} \mathrm{~A}$ third consequence has been a backlash against affirmative action policies, widely perceived by many whites to be giving unfairly employment and educational opportunities to "less qualified" minorities. ${ }^{314}$

Another source of racial retrenchment in the wake of the Second Reconstruction has been the simple persistence of overt and covert racial prejudice in social interaction. In the form of the notorious "Southern strategy," anti-black racism became a mainstay of presidential politics beginning with President Nixon. ${ }^{315}$ Words like "welfare" and "crime" became code words for African Americans. ${ }^{316}$ Anti-Asian prejudice operated in more complex ways in the 1980s and 1990s; the stereotype of Asian Americans as the "model minority," some have argued, has been used both to denigrate blacks and Latinos and to patronize, covertly, Asian Americans themselves. ${ }^{317}$

Apart from overt prejudice against people of color-now frequently attributed to cultural rather than biological failings-unconscious prejudice and ordinary "cognitive bias" continue to constitute a built-in headwind against which individual persons of color must struggle in their everyday

312. See Karst, supra note 310, at 528.

313. On the return of racial nativism in the 1980s and 1990s and its connection with antiimmigrant policies, see, for example, Ruben J. Garcia, Critical Race Theory and Proposition 187: The Racial Politics of Immigration Law, 17 Chicano-Latino L. Rev. 118 (1995); Kevin R. Johnson, An Essay on Immigration Politics, Popular Democracy, and California's Proposition 187: The Political Relevance and Legal Irrelevance of Race, 70 WASH. L. REv. 629 (1995). For arguments that anti-Asian sentiment and violence in the 1980s and 1990s reflected racial nativism, see, for example, Cynthia Kwei Ying Lee, Beyond Black and White: Racializing Asian Americans in a Society Obsessed with O.J., 6 HAstings WoMen's L.J. 165 (1995); Robert S. Chang \& Keith Aoki, Centering the Immigrant in the Inter/National Imagination, 85 CALIF. L. REv. 1395 (1997).

314. See EDSALL \& EDSALL, supra note 305, at 186 ("affirmative action pits a strong majority of blacks in favor of preferences (to correct for past discrimination) against overwhelming majorities of whites deeply opposed to such programs"); id. at 182 (reporting that in 1985 focus-group sessions with white voters who had defected from the Democratic Party had concluded, "The special status of blacks is perceived by almost all of these individuals as a serious obstacle to their personal advancement").

315. See id.

316. See id. at 224.

317. See Natsu Taylor Saito, Model Minority, Yellow Peril: Functions of "Foreigntess" in the Construction of Asian American Legal Identity, 4 AsIAN L.J. 71 (1997); Robert S. Chang, Toward an Asian American Legal Scholarship: Critical Race Theory, Post-Structuralism, and Narrative Space, 81 CALIF. L. Rev. 1241 (1993). 
lives. ${ }^{318}$ Social science research indicates that whites continue to identify with other whites in interactions involving strangers, resulting in disparate treatment based less on hostility toward people of color than on white racial solidarity. ${ }^{319}$ Some recent research suggests that awareness that one is vulnerable to harmful racial stereotyping can even depress objective testtaking performance, creating the potential for a self-fulfilling prophecy. ${ }^{320}$ The result of both conscious and nonconscious racial bias has been the continued salience of race, even among the privileged classes. ${ }^{321}$

A third source of retrenchment following the Second Reconstruction has been the reevaluation and critique of the new social movements of the 1960s. White social critics, both liberal and conservative, have criticized the race-based identity politics that has characterized antiracist social action since the late 1960s. On the left, social critics have argued that political organizing based on race has prevented the development of broader and potentially inore effective alliances based on class. ${ }^{322}$ On the right, critics argue that identity politics have fragmented America, that the professional race agitators who work in identity politics have failed to truly serve their communities, and that identity politics create a culture of victimhood which rewards passivity and blaming others for one's problems. ${ }^{323}$

Disputes over the legacy of the 1960s fueled the "culture wars" of the 1980s, in which intellectuals and academics faced off over issues such as the value of ethnic studies programs, whether the traditional canon of Western literature should be altered to make it more "multicultural," how American history should be taught, and the value of "Afrocentric" research and teaching. ${ }^{324}$ In each of these battles, conservatives stressed the need for universal, objective, and neutral standards of merit, while liberals stressed the need for "inclusion" and questioned whether any standards could be neutral. The subtext of most of these battles involved the ideals of

318. On unconscious racism, see Charles $\mathrm{R}$. Lawrence III, The Id, the Ego, and Equal Protection: Reckoning with Unconscious Racism, 39 STAN. L. Rev. 317 (1987). On cognitive bias, see Linda Hamilton Krieger, supra note 223; Linda Hamilton Krieger, Civil Rights Perestroika: Intergroup Relations after Affirmative Action, 86 CALIF. L. REv. 1251 (1998) [hereinafter Krieger, Civil Rights Perestroika].

319. See Krieger, Civil Rights Perestroika, supra note 315, at 1319-26 (reporting that empirical research in social cognition and identity suggests that this kind of solidarity results in the systematic advantage of white males).

320. See Claude M. Steele \& Joshua Aronson, Stereotype Threat and the Intellectual Test Performance of African Americans, 69 J. PERs. \& Soc. PsYCH. 797 (1995).

321. For popular works on the burdens of racism felt by affluent and successful African Americans, see Ellis Cose, The Rage of a Privileged Class (1993); Joe R. Feagin \& Melvin P. Sikes, Living with Racism: The Black Middle-Class Experience (1994).

322. See, e.g., Todd Gitlin, The Sixties (1987).

323. See, e.g., ARThur M. Schlesinger, Jr., The Disuniting of AMerica (1991) (criticizing identity politics); Dinesh D'SouzA, The ENd of Racism: Principles for a Multiracial Society (1995) (criticizing African American leaders who encourage victimhood).

324. For a variety of views from different political positions, see CULTURE WARS: OPPOSING VIEWPOINTs (Fred Whitehead ed., 1994). 
progress, civilizations and the inherent connection between Western Europe and freedom, democracy, and artistic genius: that is, the very ideals that at the beginning of the century had been summed up by the notion of the great heritage of the white race.

Finally, the sheer enormity of the American history of racism likely played a contributing role in the racial retrenchment of the 1980 s and 1990s. It is one thing, after all, to make reparations for small-scale harms and quite another to contemplate large-scale projects of political, economic, and cultural redistribution and the dramatic transformation of social institutions and practices that would result from a complete renunciation of American white supremacy and the determination to make things right. ${ }^{325}$ In this sense, the more clearly and forcefully "race power" activists spoke about the pervasiveness of American racism, the less likely (or even possible) a meamingful remedy seemed. Indeed, in the 1980s and 1990s, whites frequently felt themselves put on the defensive, morally condemned for acts they had not committed and did not sanction. ${ }^{326}$ This defensiveness easily became a defense of the status quo and the assertion of individual moral innocence, hence entitlement to one's privilege.

Each of these sources of racial tension, and probably others as well, coalesced in a cultural figure that appeared on the national stage in the late 1980s: the "angry white male." Pundits discussed this figure; politicians tried to court him; movies attempted to document him. ${ }^{327}$ Although it is too soon to say whether the angry white male represents the opening wedge of a newly resurgent and defiantly proud white identity, there are signals in places as disparate as college life and the far-right "militia movement" that white resentment may eclipse "colorblindness" as the mainstream white approach to race relations in the new century. ${ }^{328}$

\section{The Era of Sameness}

As the new social embrace of anti-racism as an important-indeed, a umiquely American-value collided with white economic anxieties, continued racial prejudice, attacks on identity politics in the name of class struggle or universal western values, and the enormity of our racial past, a new legal equilibrium was required within race law. Once again, the

325. See Eric K. Yamamoto, Racial Reparations: Japanese American Redress and African American Claims, 40 B.C. L. Rev. 477 (1998).

326. See Charles A. Gallagher, White Reconstruction in the University, 24 SocIALIST REV. 165, 170-71 (1994) (describing defensive attitudes on the part of white college students).

327. See, for example, Falling Down (Warner Brothers 1993), insightfully analyzed by Frcd Pfeil in White GuYs: StUdies In POSTMOdern DOMination and DifFerence 238-43 (1995).

328. See Calmore, supra note 224 , at 52 (arguing that the racial protests of the new right and neoconservatives have adopted some aspects of the far right's quest to reinvigorate white supremacist ideologies and policies); Gallagher, supra note 326, at 175-77 (discussing white resentment on college campuses). 
Supreme Court found itself on the front lines of the debate over what racial equality meant, and once again the members of the Court struggled to accommodate both American ideals and the reality of retrenchment. ${ }^{329}$ The elements of the new equilibrium can be found in the ambiguity of the word discrimination.

Discrimination carries two distinct connotations: to disadvantage, and to distinguish between. As the twentieth century ends, the Supreme Court has increasingly conflated these two meanings, moving toward the view that for the state to explicitly take account of race at all is the central harm of racism - or, in any case, the central prohibition embedded in the equal protection clause. ${ }^{330}$ This shift confirms the illegitimacy of the old racial order, at least in the South. Yet, because this view of discrimination also renders suspect government programs aimed at benefiting nonwhites, it provides a bulwark against the kind of thoroughgoing institutional change that would dislodge political and social elites.

The concept of discrimination serves to mediate the tension between egalitarian ideals and status quo preservation in another way. Defining the harm of racism as the act of discrimination has placed emphasis on racisin's moral implications. The essentially moralistic discourse of discrimination condemns the racialist ideologies that pervaded most of twentieth century law and public policy, but it has also placed a premium on proving individual intent to harm and distinguishing innocent victims from evil victimizers. Translated into constitutional law, this model of discrimination closely resembles criminal responsibility: it works to identify intentional wrongdoers and demonstrable victims, but leaves untouched unconscious racism, everyday cognitive bias, and institutional structures that faithfully perpetuate patterns of racial subordination. ${ }^{331}$ As the legal structures that continue to disadvantage people of color become increasingly "race-neutral" in a constitutional sense, the moral model of discrimination facilitates both the denunciation of bigotry and the maintenance of existing distributions of wealth and power.

The new equilibrium is dramatically different than the one reached in American race law following the First Reconstruction. Then, the implicit assumption was that race made humans incontestably, malterably different from one another. Racial difference could be managed, and perhaps even

329. John Calmore argues that the Court in the 1990s was in fact the strongest point in a "conservative iron triangle," consisting of the Court, the Executive branch, and Congress. Calmore, supra note 224 , at 53.

330. Compare Ronald Walters, Affirmative Action and the Politics of Concept Appropriation, 38 How. L. J. 587, 600 (1995) ("Where racial discrimination was originally defined as the prohibition or exclusion of blacks and other disadvantaged groups from access to normal or equal participation in society, it has devolved to mean any racial distinction.").

331. Compare Alan Freeman, Antidiscrimination Law: The View from 1989, 64 TuL. L. Rev. 1407,1431 (1990) (comparing antidiscrimination law to the law of intentional torts). 
eradicated over time, but it could not be denied. Now, the implicit assumption is that race makes no difference. Far from being real and unalterable, race is a fiction, an arbitrary and meaningless concatenation of phenotypical differences that has no connection to human worth or character. The United States has finally embraced, at least in public, the conviction that people should be judged by the content of their character, not the color of their skin.

Yet, ironically, antiracist activists have not rushed to embrace this philosophy. Instead, a significant proportion of people of color have insisted on the continuing importance of race and demanded that the law be race-conscious rather than race-blind. As a result, it is as if the two sides of the battle have switched places, but the struggle remains the same. Equality as "difference," equality as "sameness": both conceptions can serve as a framework for a battle over the distribution of power.

As the century ends, the discourse on race in the Supreme Court has at least three characteristic features: its conflation of discrimination as disadvantage and discrimination as differentiation; its requirement of "intent," narrowly defined, in order to establish discrimination; and the persistent subtextual suggestion that American racism is simply too pervasive and too complex for courts-or even nonstate actors such as employers and schools-to try to remedy.

\section{Discrimination as Differentiation}

In Adarand Constructors, Inc. v. Pena, ${ }^{332}$ the Court considered whether the federal government had violated the equal protection component of the Fifth Amendment Due Process Clause when it established a presumption in its contracting regulations that "[B]lack, Hispanic, Asian Pacific, Subcontinent Asian, and Native Americans, as well as 'members of other groups designated from time to time by [the Small Business Administration],' are 'socially disadvantaged." ${ }^{333}$ Under the Small Business Act and Department of Transportation regulations, government contractors who hired subcontractors owned and controlled by "socially and economically disadvantaged individuals" ${ }^{334}$ received monetary compensation from the government, which gave such subcontractors an edge in competitive bidding. The government argued that the program was based on disadvantage, not race, and should therefore receive the most lenient judicial scrutiny. The plaintiff, a subcontractor that had lost a contract to a subcontractor certified as disadvantaged, argued that the program was a racial preference that should receive strict scrutiny.

332. 515 U.S. 200 (1995).

333. Id. at 207 (citation omitted).

334. Id. at 206. 
Writing for the Court, Justice O'Connor agreed with Adarand that the provision should receive the highest level of judicial scrutiny. She identified three propositions from the Court's twentieth-century jurisprudenceskepticism, consistency, and congruence ${ }^{335}$ - which together suggested a governing principle: "[A]ny person, of whatever race, has the right to demand that any governmental actor subject to the Constitution justify any racial classification subjecting that person to unequal treatment under the strictest judicial scrutiny." ${ }^{336}$ O'Connor quoted from a dissent by Justice Stevens in an earlier case:

[B]ecause racial characteristics so seldom provide a relevant basis for disparate treatment, and because classifications based on race are potentially so harmful to the entire body politic, it is especially important that the reasons for any such classification be clearly identified and unquestionably legitimate, [and] [r]acial classifications are simply too pernicious to permit any but the most exact connection between justification and classification. ${ }^{337}$

The Court remanded the case for an inquiry as to whether the government's race-based action was narrowly tailored to serve a compelling state interest.

The decision in Adarand overruled an earlier case, Metro Broadcasting, Inc. v. FCC, ${ }^{338}$ in which the Court held that "benign" federal racial classifications-those intended to help, rather than harm, racially subordinated groups-should receive a lower level of scrutiny. In response to the argument that the difference between "benign" and "malign" racial classifications justifies different levels of scrutiny, Justice O'Connor again quoted from Stevens' dissent in Fullilove:

Even though it is not the actual predicate for this legislation, a statute of this kind inevitably is perceived by many as resting on an assumption that those who are granted this special preference are less qualified in some respect that is identified purely by their race. Because that perception-especially when fostered by the Congress of the United States - can only exacerbate rather than reduce racial prejudice, it will delay the time when race will become a truly irrelevant, or at least insignificant, factor. ${ }^{339}$

335. By "skepticism," the Court meant that "[a]ny preference based on racial or ethnic criteria must necessarily receive a most searching examination." Id. at 223 (quoting Wygant v. Jackson Bd. of Educ., 476 U.S. 267 (1986) (plurality opinion of Powell, J.)). By "consistency," the Court meant that the standard of review for racial classifications is the same whether whites or nonwhites are burdened by them. See id. at 224. By "congruence," the Court meant that equal protection analysis under the Fifth Amendment is the same as under the Fourteenth Amendment. See id.

336. Id. at 224.

337. Id. at 236 (quoting Fullilove v. Klutznick, 448 U.S. 448, 533-35, 537 (1980) (Stevens, J., dissenting)).

338. 497 U.S. 547 (1990).

339. Adarand Constructors, Inc. v. Pena, 515 U.S. 200 (1995) (quoting Fullilove v. Klutznick, 448 U.S. 448, 545 (1980) (Stevens, J., dissenting) (emphasis added)). 
Although O'Connor took pains to emphasize that strict scrutiny should not automatically mean striking down the statute, these quotes suggest a turn toward the view that the practice of racial classification itself lies at the heart of racism. Justice Scalia, concurring, made this point explicitly: "To pursue the concept of racial entitlement--even for the most admirable and benign of purposes-is to reinforce and preserve for future mischief the way of thinking that produced race slavery, race privilege and race hatred. ${ }^{1340}$ Justice Thomas went even further, invoking the spirit of Plessy:

I believe that there is a "moral [and] constitutional equivalence," between laws designed to subjugate a race and those that distribute benefits on the basis of race in order to foster some current notion of equality. Government cannot make us equal; it can only recognize, respect, and protect us as equal before the law. ${ }^{341}$

The equation of discrimination with differentiation squarely confronts and rejects the outright racial management of the Plessy era. Yet this equation also clearly limits what can be done to remedy pervasive racial subordination; understands "race" itself as a meaningless physical attribute rather than a meaningful social practice; and identifies racism as a moral harm committed against individuals, rather than a material harm committed against groups. ${ }^{342}$

The most obvious consequence of the discrimination-asdifferentiation position is the practical effect of Justice Thomas' view: the elimination of all government-sponsored affirmative action. Conservative legal activists have been working toward this very goal, bringing lawsuits against educational institutions that consider race as a factor in admissions decisions, and sponsoring state initiatives to eliminate all racial "preferences" in employment as well as education. ${ }^{343}$ If one assumes with Justice O'Connor, however, that racial discrimination in social life has not ended, the abolition of such programs simply reestablishes government acquiescence to "social" inequality.

A second, more subtle consequence of discrimination-asdifferentiation is the view that race is fundamentally biological after all,

340. Id. at 239 (Scalia, J., concurring).

341. Id. at 240 (Thomas, J., concurring) (citation omitted).

342. Contemporary critical race theorists have critiqued each of these positions in some detail. See, e.g., John O. Calmore, "Naked People," supra note 224; Alan Freeman, supra note 331; Neil Gotanda, A Critique of "Our Constitution is Colorblind," supra note 126; Cheryl Harris, Whiteness as Property, 106 HARv. L. Rev. 1707 (1993); Jayne Chong-Soon Lee, Navigating the Topology of Race, in Critical Race Theory: The Key Writings That Formed the Movement 441 (Kimberle Crenshaw et al. eds., 1995).

343. See Jean Stefancic \& Richard Delgado, No Mercy: How Conservative Think TANKS ANd Foundations Changed AMerica's Social Agenda 60, 78 (1996). 
and that racism is hence a rational error. ${ }^{344}$ The Court's most famous statement of this position with respect to equal protection law is in its 1973 opinion in Frontiero $v$. Richardson:

[S]ince sex, like race and national origin, is an immutable characteristic determined solely by the accident of birth, the imposition of special disabilities upon the members of a particular sex because of their sex would seem to violate "the basic concept of our system that legal burdens should bear some relationship to individual responsibility...." And what differentiates sex from such non-suspect statuses as intelligence or physical disability, and aligns it with the recognized suspect criteria, is that the sex characteristic frequently bears no relation to ability to perform or contribute to society. ${ }^{345}$

On this view, "because there are no relevant differences between the races, legislative distinctions based upon race are presumptively (and strongly so) not rational, and therefore they are illegitimate." ${ }^{346}$ This view, of course, assumes that race is always used as a biological category, for surely there are relevant differences between the "races" if that concept refers to social classes. Thus, commentators have strongly criticized the Supreme Court's recent voting rights opinions which, in emphasizing the meaninglessness of race, simultaneously overlook the political realities of racial solidarity. ${ }^{347}$

The Court's move toward the view that race is not a legitiunate basis for political alliance, along with its purely biological understanding of race, has put increasing pressure on the structure of federal Indian law and placed the Court at odds with leaders of indigenous peoples who seek selfdetermination. In Morton v. Mancari, ${ }^{348}$ the Court upheld BIA employment preferences for Indians as "political," not "racial," preferences ${ }^{349}$-even though the preferences were defined in terms of blood quantum. Blood quantum and other quasi-biological indicia of descent are in fact common factors in legal definitions of indigenous peoples. If government use of such indicia are ruled unconstitutional, the significance of race as a marker of political, cultural, and social identity will be lost. ${ }^{350}$ The Court's focus on

344. See Robin West, Toward an Abolitionist Interpretation of the Fourteenth Amendment, $94 \mathrm{~W}$. VA. L. REv. 111, 111-13 (1991) (describing the view that the Equal Protection Clause is a guarantee of legislative rationality).

345. Frontiero v. Richardson, 411 U.S. 677, 686 (1973) (citation omitted).

346. Daniel A. Farber et al., Cases and Materials on Constitutional law: Themes for THE CONSTITUTION's ThiRd CENTURY 136 (2d ed. 1998).

347. See, e.g., KoussEr, supra note 40, at 451-53 (arguing that recent Supreme Court decisions on voting rights have turned the Reconstruction Amendments and the Voting Rights Act into laws to diminish minority political power).

348. 417 U.S. 535 (1974).

349. Id. at 553-54 \& n.24.

350. See David C. Williams, The Borders of the Equal Protection Clause: Indians as Peoples, 38 UCLA L. REv. 759 (1991) (arguing that federal Indian law is indefensible under basic American principles of racial equality and vulnerable to equal protection challenge). But see Carole GoldbergAmbrose, Not "Strictly" Racial: A Response to "Indians as Peoples," 39 UCLA L. REv. 169 (1991). 
the meaninglessness of race thus has the potential, paradoxically, to undermine the political power of racially subordinated groups.

The judicial understanding of race as an "immutable trait" has also limited the protections of antidiscrimination law. For example, the distinction between "immutable" traits such as color and "mutable" traits such as language and hairstyle renders the latter unprotected by race discrimination statutes such as Title VII. As the authors of a leading treatise on Title V1I describe the state of the law, "Under disparate treatment theory, discrimination on the basis of an immutable characteristic associated with race, such as skin color or facial features, violates Title VII even though not all members of the race share the characteristic." ${ }^{351}$ The corollary is that discrimination based on a "mutable" characteristic does not violate Title VII, even if many members of a "racial" or national origin group do share it.

As a practical matter, this focus on race as an immutable trait means that merely "cultural" behaviors and practices do not receive legal protection unless they can be strongly linked back to the "immutable" characteristics of race or national origin. ${ }^{352}$ Thus, English-only requirements and grooming standards based on Anglo customs may be imposed upon a multi-racial work force. ${ }^{353}$ The separation of "race" from "culture," like the discrimination-is-differentiation position, gives employers and government agencies broad room to force employees marked as racially "other" to assimilate to a socially "white" standard. ${ }^{354}$ Trait-based thinking also prevents the courts from recognizing the operation of intergroup discrimination: it becomes difficult to see how members of a disadvantaged group might discriminate against other members of the same group, for

In Rice v. Cayetano, 120 S. Ct. 1044 (2000), the Court held that voting limitations based on Hawaiian ancestry in trusteeship elections for the Office of Hawaiian Affairs violated the Fifteenth Amendment because they constituted racial restrictions. In dissent, Justice Stevens argued that the holding thwarted the obvious inteut of the restriction: to fulfill the Unitcd States' special obligation to indigenous peoples.

351. B. Schlei and P. Grossman, Employment Discrimination LaW 290 (1983); see also Willingham v. Macon Tel. Publ'g Co., 507 F.2d 1084, 1091 (5th Cir. 1975) ("Equal employment opportunity may be secured only when employers are barred from discriminating against employees on the basis of immutable characteristics ... [orl some fundamental right.") (emphasis added); Peter Brandon Bayer, Mutable Characteristics and the Definition of Discrimination under Title VII, 20 U.C. DAvis L. REv. 769 (1987).

352. See Juan F. Perea, Ethnicity and Prejudice: Reevaluating "National Origin" Discrimination under Title VII, 35 WM. \& MARY L. REv. 805, 851 (1994).

353. See, e.g., Garcia v. Spun Steak Co., 998 F.2d 1480 (9th Cir. 1993) (upholding "English only" policy); Rogers v. Am. Airlines, 527 F. Supp. 229 (S.D. N.Y. 1981) (upholding policy forbidding allbraided hairstyles).

354. For arguments to this effect, see, for example, Christopher David Ruiz Cameron, How the Garcia Cousins Lost Their Accents: Understanding the Language of Title VII Decisions Approving English-Only Rules as the Product of Racial Dualism, Latino Invisibility, and Legal Indeterminacy, 85 Calif. L. Rev. 1347 (1997); Juan F. Perea, Los Olvidados: On the Making of Invisible People, 70 N.Y.U. L. REv. 965 (1995). 
example. ${ }^{355}$ Perhaps most subtly, the reduction of race to a biological trait perpetuates racial thinking by treating "race" as real, a "trait" that people have, and it encourages judges to categorize individuals by examining their personal traits rather than examining the social relations between persons and among groups.

Finally, as a rhetorical matter, the equation of racial discrimination with racial differentiation fosters the moral absolution of whites for the history of racial domination. In actuality, the United States has been plagued not with a surfeit of racial classifications as such, but rather with the consistent use of racial classifications to privilege (certain groups of) whites and disadvantage nonwhites. The Court's focus on classification itself as the problem, however, makes it possible to equate that history with present white claims of "reverse discrimination. ${ }^{3356}$ In addition, the focus on classification itself-because it makes suspect race-conscious action taken to combat racism-justifies the maintenance of existing social and political relations. ${ }^{357}$ In short, it permits a compromise in which whites renounce attempts at openly racist domination in exchange for keeping formally "race-neutral" (but covertly race-conscious) practices and policies sacrosanct.

\section{The Rule of Intent: Distinguishing "Racial" from "Nonracial" Action}

As scholars have observed, the concept of "discriminatory intent" was not an inevitable element of equal protection jurisprudence. ${ }^{358}$ Indeed, the Court's statements in Brown v. Board of Education and its progeny about why segregation of all kinds violated the equal protection clause were perhaps deliberately Delphic. At the beginning of the Brown era, the Court's failure to specify the reason for striking down segregation in all its forms was unproblematic, since outright legal regulation on the basis of race was so common and had become so morally problematic ${ }^{359}$ From the late 1960 s into the 1970s, however, the lower federal courts began to reach beyond the explicitly race-conscious government practices of Jim Crow to hold unconstitutional practices that were not racially marked, yet had the effect of disadvantaging racial minorities. This development had the potential to destabilize a whole new set of social, economic, and political arrangements.

School segregation in the North, for example, had been accomplished not primarily through explicit racial segregation, but rather indirectly through private residential segregation. In 1973, in its opinion in Keyes $v$.

355. See Kathryn Abrams, Title VII and the Complex Female Subject, 92 MicH. L. Rev. 2479, 2516-17 (1994).

356. Adarand Constructors, Inc. v. Pena, 515 U.S. 200 (1995).

357. See Harris, Whiteness as Property, supra note 342, at 1767.

358. See Siegel, supra note 10, at 1132-33.

359. See id. at 1132. 
School District. No. $1,{ }^{360}$ the Court examined a district in Denver, Colorado in which Latino and African American students predominated in one school and Anglo students in another. The Court might have placed the burden on justifying this segregation on the school district; instead, it focused on the need for plaintiffs to prove "segregative intent" in order to state a claim. Three years later, in Washington v. Davis, ${ }^{361}$ the Court built on Keyes to announce a sharp distinction between the Equal Protection Clause and Title VII of the Civil Rights Act of 1964. Whereas Title VII permitted a case to go forward solely on the basis of proven discriminatory "effects," the Court stated that in constitutional cases the evidence must reflect "the basic equal protection principle that the invidious quality of a law claimed to be racially discriminatory must ultimately be traced to a racially discriminatory purpose. ${ }^{362}$

The Court elaborated on what "purpose" meant in its 1979 decision in Personnel Administrator v. Feeney. ${ }^{363}$ " 'Discriminatory purpose' ... implies more than intent as volition or intent as awareness of consequences. It miplies that the decisionmaker ... selected or reaffirmed a particular course of action at least in part 'because of,' not merely 'in spite of' its adverse effects upon an identifiable group." ${ }^{364}$ As Siegel points out, this version of purpose goes beyond the tort standard of foreseeability and even the criminal law concept of "knowledge"; it equates discriminatory purpose with criminal malice. ${ }^{365}$

In Title VII jurisprudence, the courts have similarly shaped litigation procedure in the direction of this conscious imtent model of discrimination. In so-called mixed motive cases, for example, the defendant wins if it can demonstrate a nondiscriminatory reason for taking action against the plaintiff, even if discriminatory animus was admittedly one reason for its action. ${ }^{366}$ Even where evidence of "disparate impact" can establish a prima facie case, the courts have emphasized the plaintiff's ultimate burden of proving invidious intent. ${ }^{367}$

One practical effect of the courts' emphasis on intent has been to make it extremely difficult to win discrimination suits. Since regulated institutions adjust their practices to the regulatory environment, employers,

\footnotetext{
360. 413 U.S. 189 (1973).

361. 426 U.S. 229 (1976).

362. Id. at 240 (quoting Keyes, 413 U.S. at 205). The Court was aware that the line between a "purpose" and an "effects" test may be blurry, since evidence about the effects of a policy may be introduced to prove the purpose of the policy. See, e.g., Village of Arlington Hcights v. Metro. Hous. Dev. Corp., 429 U.S. 252 (1977) (outlining procedure for proving intent through circumstantial evidence in administrative decisions); Washington, 426 U.S. at 254 (Stevens, J., concurring).

363. 442 U.S. 256 (1979).

364. Id. at 279 (citation omitted).

365. See Siegel, supra note 10 , at 1134-35.

366. See Krieger, supra note 223, at 1171-72.

367. See id.
} 
legislators, and others subject to discrimination suits can be expected to conceal their consciously discriminatory practices. Perhaps more disturbingly, the criminal intent rule insulates from judicial scrutiny forms of bias that are unconscious or cognitive in origin. ${ }^{368}$ Since social science research indicates that bias is a predictable effect of ordinary cognitive functioning in a world pervaded by group stereotypes, ${ }^{369}$ this legal rule would suggest that perhaps the most common form of racial discrimination is not illegal.

A second critique of the intent requirenient is the political and social effect of declaring that racisni only exists when an individual consciously seeks to harm another because of race. This moralistic, individualist model of discrimination reflects the Suprenie Court's long-standing view that the Constitution protects individuals, not groups; but it also means that "institutional racism"- the interaction of complex social systenis to reinforce patterns of racial subordination-remains untouched by antidiscrimination law. For example, to require a history of conscious discrimination by the very entity now undertaking the program-the position toward which the courts seem to be moving ${ }^{370}$ - will make it difficult to remedy discrimination in complex employment and educational systems where people of color are disadvantaged by an accretion of small, perhaps nonintentional, strikes against them. Indeed, one critique of the Court's individualist model of discrimination is that it reinforces the notion that whatever practices lie outside the realm of invidious, conscious bigotry, are a "neutral," "natural" outcome of free choice in social relations. ${ }^{371}$ In this view, for example, "affirmative action" appears to represent an interference with natural market ordering, a clumsy attempt by the state to introduce "social engineering" into otherwise neutral social relations. Yet, if one views the market itself not as the product of natural social relations outside the state, but as a set of mechanisms themselves already shaped by state action-including race law-"affirmative action" looks less anomalous. ${ }^{372}$

The Court's intent rule in equal protection jurisprudence, and the ripple effects of the rule on other areas of antidiscrimination law, have been

368. See generally id.; Krieger, Civil Rights Perestroika, supra note 319.

369. See Krieger, supra note 223, at 1171-72.

370. See, e.g., Hopwood v. Texas, 78 F.3d 932 (5th Cir. 1996) (holding that University of Texas Law School cannot justify race-conscious admissions plan by reference to discrimination anywhere but in the law school itself), cert. denied, 518 U.S. 1033 (1996).

371. See, e.g., SUNSTEIN, supra note 163, at 78.

372. For example, the debate over whether "race" or "class" explains why minority neighborhoods are so often plagued by locally unwanted land uses assumes that market relations are not pervaded by race relations. See Sheila Foster, Justice from the Ground Up: Distributive Inequities, Grassroots Resistance, and the Transformative Politics of the Environmental Justice Movement, 86 CALIF. L. REv. 775 (1998). For an effort to use economic theory to show the interdependence of the federal government and private markets, see lan Ayres \& Frederick E. Vars, When Does Private Discrimination Justify Public Affirmative Action?, 98 Colum. L. REv. 1577 (1998). 
widely criticized. Yet the Court's approach makes sense if one assumes the point of the rule is not to maximize application of antidiscrimination norms but rather to cabin them within tolerable social limits. Indeed, the intent rule reflects both the positive and negative aspects, from an antiracist point of view, of the success of antiracism as a moral project. The elevation of antiracism to a fundamental moral principle in American life represents the strongest repudiation yet of centuries of race-based slavery, violence, exploitation, and exclusion in constitutional and political discourse. Yet the moralization of antiracism has at the same time limited its potential effects. Socially, it allows everyone who is not actually a racist skinhead or member of the Ku Klux Klan to feel innocent, to condemn racism without taking any responsibility for one's own unwitting complicity with it. Legally, it insulates vast expanses of American life from scrutiny and attributes discriminatory effects to preference, "private" bigotry, or the faults of racial minorities themselves.

\section{Racism and the Limits of Courts}

Prudential matters, finally, have contributed to the Court's reluctance to take the principles of racial equality too far. After the heady days of the Warren and Burger Courts, when the justices seemed confident in their ability to make progressive change, the Court has moved back toward the assumption that judges cannot and slould not engage in "social engineering." An example is the Court's lack of interest in racial subordination in the criminal justice system. Unlike issues of education and employment, where racial prejudice is often nonconscious and its effect deeply interwoven witl issues of economics and politics, racial discrimination in the criminal justice system is both blatant and has had stunningly dramatic effects. ${ }^{373}$ Yet, while the Court has recently extended protection against racial discrimination in the selection of juries, ${ }^{374}$ when it comes to sentencing schemes that consign vast proportions of African American and Latino men to jail, prison, and probation, the Court has demonstrated little enthusiasm for recognizing the possibility of racial discrimination.

For example, in McCleskey v. Kemp, ${ }^{375}$ the Court considered claims, based on the Eighth and Fourteenth Amendments, that the Georgia capital punishment statute was unconstitutional because persons who murdered whites were more likely to be sentenced to death than persons who

373. See David Cole, No Equal Justice: Race and Class in the American Criminal Justice System (1999); CoRAmae Richey ManN, Unequal Justice: A Question of Color (1993); Michael Tony, Malign Neglect: Race, Crime, and Punishment in America (1995); The Report of the National Criminal Justice Commission, THE REAL WAR ON CRIME (Steven R. Donziger ed., 1996); Harriet Chiang, Drug War Jailing Blacks Unequally, S.F. CHRoN., June 8, 2000 , at A3.

374. See Georgia v. McCollum, 505 U.S. 42 (1992); Powers v. Ohio, 499 U.S. 400 (1991); Batson v. Kentucky, 476 U.S. 79 (1986).

375. 481 U.S. 279 (1987). 
murdered blacks, and because black murderers were more likely to be sentenced to death than white murderers. The Court held that because the plaintiff could not demonstrate intentional discrimination im his own case, but relied on a sophisticated statistical analysis, his claim must fail. Writing for the Court, Justice Powell noted that McCleskey's claims "challenge[] decisions at the heart of the State's criminal justice system,",376 and led to the opening of the proverbial floodgates:

[I]f we accepted McCleskey's claim that racial bias has impermissibly tainted the capital sentencing decision, we could soon be faced with similar claims as to other types of penalty. Moreover, the claim that his sentence rests on the irrelevant factor of race easily could be extended to apply to claims based on unexplained discrepancies that correlate to membership in other minority groups, and even to gender. ${ }^{377}$

Here the Court dropped a footnote quoting from Justice Powell's opinion in Regents of the University of California v. Bakke, ${ }^{378}$ noting that "the national 'majority' is composed of various minority groups, most of which can lay claim to a history of prior discrimination at the hands of the State and private individuals." becoming a minority in many of the larger American cities," possibility that white defendants could claim discrimination, and remarked that "in our heterogeneous society the lower courts have found the boundaries of race and ethnicity increasingly difficult to determine." 381 The specter of pervasive racial discrimination was, paradoxically, a reason for refusing to recognize a claim. Justice Brennan, in dissent, accused the majority of "a fear of too much justice." 382

This skepticism about the ability to remedy pervasive discrimination at tinies extends not just to judges, but to nonstate actors as well. The Court has been adamant, for example, that the remedy of mere "societal discrimination" is not a compelling state interest that justifies voluntary affirmative action programs. Societal discrimination, various opmions have asserted, is too vague, speculative, and potentially far-reaching to justify race conscious action. ${ }^{383}$



381. Id. See also Alexandra Natapoff, Trouble in Paradise: Equal Protection and the Dilemma of Interminority Group Conflict, 47 STAN. L. REv. 1059, 1062 (1995) (examining recent cases in which the Supreme Court suggests that claims of discrimination are increasingly undecidable given that we are a nation of minorities).

382. McCleskey, 481 U.S. at 339 (Brennan, J., dissenting).

383. See, e.g., City of Richmond v. J. A. Croson, 488 U.S. 469, 499 (1989) (holding that the city of Richmond's plan to give preference to minority contractors cannot be justified by history of past 
As a practical matter, these decisions and dicta can be read as a tacit admission that racial discrimination has woven itself so deeply into the fabric of American life that no court can hope to extirpate it. As a rhetorical matter, however, these decisions and dicta also potentially offer a different message: they construct a world in which claims of racial discrimination themselves are pervasive, speculative, undecidable, and ultimately harmful to the nation.

\section{CONCLUSION: RACE LAW AND EQUALITY TROUBLE}

I have argued that now, at the close of the twentieth century, the Court has found a new way to reconcile race law with the realities of racial subordination. The century witnessed a movement within race law from race as "difference" to race as "sameness," as well as a movement toward equality as the central principle of race law. But as feminist scholars have noted, within the language of equality both sameness and difference frameworks can elide the question of power: Who is setting the standards by which sameness and difference are to be judged? How neutral are the social practices and institutions into which formerly excluded groups are now to be included $?^{384}$ Sameness and difference frameworks elide, as well, a different sort of power issue: To what extent are our very perceptions of sameness and difference shaped by simplifying conceptual schemes, by unmarked privileges, by ignorance of the reciprocal relationship between the observer and the observed? ? $^{385}$

Finally, the equality framework, whether focused on race as a real difference or an arbitrary fact that makes no difference, eludes questions of freedom and justice. If law cannot make us "equal," are there ways it can help us be free? How should the United States come to terms with its long history, continuing into the present and future-of racial subordination? Neither the conclusion that race makes us different, nor that race is meaningless, nor commitment to racial equality, as hard-won as it has been, can answer these questions.

At least three alternatives seem possible for the next century. At one extreme is the vindication of the "sameness" era represented by the Second Redemption: a society in which people of many skin hues may succeed as long as they meet a single standard marked by formally "neutral" requirements of behavior, and in which the criminal justice system is dispatched

discrimination in the construction industry, since "[i]t is sheer speculation how many minority firms there would be in Richmond absent past societal discrimination").

384. See Catharine A. MacKinnon, Toward a Feminist Theory of the State (1989).

385. See Martha Minow, Making All the Difference: Inclusion, Exclusion, and AMERICAN LAW 50-74 (1990) (describing five unstated assumptions underlying "difference dilemmas"). 
to deal with all the rest. ${ }^{386}$ At the other extreme is the color-obsessed vision of America put forth by the racist far right, who advocate the repeal of the Reconstruction Amendments, a massive reduction in the size and strength of the federal government, and a declaration that the only true American citizens, the true "People of the United States," are the white descendants from the original forefathers. ${ }^{387}$ In the middle between assimilation and expulsion, colorblindness and color hierarchy, stand proponents of a "multicultural America," one that seeks justice through recognition and redistribution along racial lines, yet also affirms solidarity in diversity. Whether such a society is possible remains to be seen.

386. Cf. Jonathan Simon, Ballad of a Thin Man: Sociological Studies in a Time of Postmodern Crisis, 29 L. \& Soc'y REv. 631 (1995) (suggesting that "two governments" are emerging in the United States: one largely private and devoted to discipline, the second largely state-based and devoted to coercion). Some of my colleagues have suggested that in this brave new world, whites and successful people of color will be viewed as having "transcended" race, while the largely black and brown underclass will be perceived through the usual racial stereotypes. See, e.g., John Powell, Charles Lawrence, and Ian Haney-Lopez, Remarks at Joint Conference of the Asian Pacific American Law Teachers and the Western Law Teachers of Color, Turtle Bay Hilton, Oahu, Hawaii, June 3, 2000.

387. See Susan P. Koniak, When Law Risks Madness, 8 Cardozo Stud. L. \& Literature 65 (1996); David C. Williams, Civic Republicanism and the Citizen Militia: The Terrifying Second Amendment, 101 Yale L.J. 551 (1991); David C. Williams, The Militia Movement and Second Amendment Revolution: Conjuring with the People, 81 CoRNELl L. Rev. 879 (1996). 
